\title{
The Distribution, Abundance and Ecology of Mixotrophic Algae in Marine and Freshwater Plankton Communities
}

by

\author{
Andrea Lynn Arenovski
}

B.S., University of North Carolina at Wilmington (1988)

Submitted to the Joint Committee for Biological Oceanography in Partial Fulfillment of the Requirements for the Degree of Doctor of Philosophy

at the

Massachusetts Institute of Technology

and the

Woods Hole Oceanographic Institution

September 1994

(c) 1994 Andrea L. Arenovski. All rights reserved.

The author hereby grants to MIT and WHOI permission to reproduce and distribute publicly paper and electronic copies of this thesis document in whole or in part.

Signature of author

Joint Program in Oceanography Massachusetts Institute of Technology/

$\cap$ Yoods Hole Oceanographic Institution

Certified by

1

David A. Caron, Thesis Supervisor Department of Biology Woods Hole Oceanographic Institution

Accepted by.

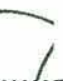

Donald M. Anderson, Chairman Joint Committee for Biological Oceanography

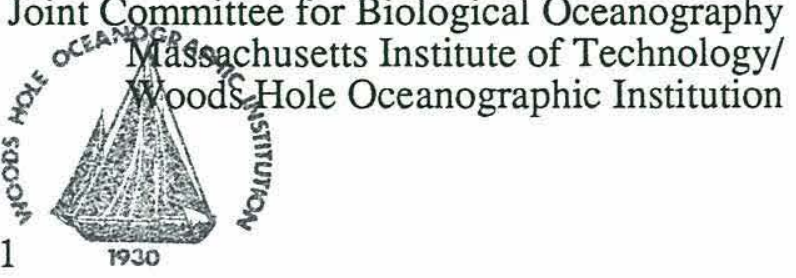


Distribution, Abundance and Ecology of Mixotrophic Algae in Marine and Freshwater Plankton Communities

\author{
by \\ Andrea Lynn Arenovski \\ Submitted in partial fulfillment of the requirements for the degree of \\ Doctor of Philosophy
}

\begin{abstract}
Mixotrophic algae are algae that combine photosynthesis with phagotrophy to satisfy nutritional requirements. Mixotrophic algae have been found to dominate the nanoplankton assemblage in some aquatic environments, and algal phagotrophy can account for a significant fraction of total bacterivory on occasion. The distribution and abundance of mixotrophic algae have not been widely characterized, however, and the factors that control their abundances and phagotrophic activity in aquatic environments are poorly understood. The vertical distribution and abundance of mixotrophic nanoplankton was therefore documented in a variety of aquatic environments including the oligotrophic open ocean (Sargasso Sea), nine freshwater seepage ponds (Adirondack Mountains, NY) and three coastal salt ponds (Falmouth, MA) using epifluorescence microscopy and fluorescently labeled prey to trace ingestion by algae. Field experiments designed to examine the influence of prey density, nutrient availability and light intensity on mixotrophic nanoplankton abundances and their phagotrophic activity were also carried out to examine the adaptive significance of phagotrophy for mixotrophic algae in surface waters of the Sargasso Sea and in the epilimnion of one freshwater seepage pond.

Mixotrophic nanoplankton abundances in the Sargasso Sea ranged from less than a few cells ml-1 to more than 140 cells ml-1, and they were more abundant in surface waters. On two occasions mixotrophic algae comprised more than $50 \%$ of the total algal nanoplankton assemblage in surface waters. The results of field experiments indicate that phagotrophy may provide mixotrophic algae in surface waters of the Sargasso Sea with major nutrients and may enable them to compete with purely phototrophic algae during periods of low nutrient concentrations.

Mixotrophic nanoplankton abundances comprised a small fraction of the total algal nanoplankton $(<5 \%)$ in most of the freshwater seepage ponds and in all three coastal salt ponds. Mixotrophic algae in the epilimnion of one freshwater pond, however, accounted for $\sim 25 \%$ of the total algal nanoplankton, and Dinobryon dominated the mixotrophic nanoplankton in this pond $\left(\sim 2 \times 10^{4}\right.$ Dinobryon $\left.\mathrm{ml}^{-1}\right)$. Results from field experiments support the hypothesis that nutrient acquisition is an important secondary function for phagotrophy in Dinobryon, but that the primary function may be to provide essential growth factors.
\end{abstract}

Thesis Supervisor: David A. Caron, Associate Scientist, Woods Hole Oceanographic Institution 


\section{ACKNOWLEDGMENTS}

Many people contributed to my growth as a scientist during my six years at WHOI and I am indebted to all of them for their support, guidance and encouragement. In particular, my thesis advisor Dave Caron deserves special thanks. Our discussions over the last three years never failed to provide me with encouragement and new direction. I will always look back fondly on my graduate experience under his guidance. I am also grateful to my other committee members; Penny Chisholm, Paul Dunlap, Judy McDowell and Bob Sanders. Their comments greatly improved this thesis, and their encouragement throughout was invaluable to my professional development. Thanks also go to Lauren Mullineaux who served as Chair of the thesis defense proceedings and who provided me with the memory of a lifetime, a first hand view of the deep sea through the port holes of DSV Alvin. Brian Howes and John Teal also deserve thanks for guidance early on in my graduate career at WHOI.

Data for this thesis was generated through field sampling which would not have been possible without the assistance of several people. I would like to thank Jim Moffett, who made the work in the Sargasso Sea possible by providing me with laboratory space aboard the RV Endeavor during cruise leg 234. Carla Bold and Dave Hutchins are also thanked for their assistance in water collections during the cruise. Paul Bukaveckas was instrumental in carrying out the work in the Adirondacks. Paul provided me with access to his study sites and a field laboratory in which to process samples. He also assisted in field experiments and data collection. His assistants, Kim Bowes and Bill Shaw are also thanked for their invaluable help in the field. The work in the coastal ponds would not have been possible without assistance from Brindha Muniappan. Brindha's friendship and assistance in the field and the laboratory are greatly appreciated.

This thesis would also not have been possible without many, many hours spent filtering samples and enumerating cells in a dark microscope room. I would like to thank Ulrike Berninger and Ee lin Lim for guiding me through laboratory and microscopy techniques, and for teaching me how to survive the "misery room". Linda

Amaral Zettler and Mark Dennett were also very helpful in the lab and their friendship is greatly appreciated. Members of the Howes' Lab; Susan Brown-Leger, Dave Schlezinger, Richard Van Etten, Dave White and Tony Millham are also thanked for their friendship during my early years in the Howe's Lab and for assistance with nutrient analyses. Guidance and assistance with statistical analyses from Andy Solow and Vicki Starczak are also acknowledged.

I am deeply indebted to my friends and family. Their unending support and encouragement were essential in maintaining my sanity throughout graduate school. I especially want to thank Steve Shephard for his love and encouragement. I have drawn my strength from his companionship and never-ending confidence in me and for that I am eternally grateful. I also want to express my thanks to my Mom for all her encouragement and her continuing faith in my abilities. Without her support none of this would have been possible. My brothers, Jay and Dan also deserve special thanks for their understanding and support. My friends provided the fun, exercise, discussion and much of the encouragement that were so necessary for my survival in Woods Hole. I particularly want to thank Liese Siemann, Susie McGroddy, Cheri Recchia and John Kokinos. We went through a lot together as friends, classmates and housemates and the memories will be with me always. Many others deserve mention here as well, but the list is long. I do want to thank my housemates Gary Jaroslow and Deana Erdner. They endured my moods in the final throes of writing and for this they deserve special medals! I also want to acknowledge the friendship of Stacy Kim and Kendall Banks and everyone at Cape Cod Underwater Hockey. There are many other friends who also deserve thanks. I hope you know who you are! 
Finally, I want to express my thanks to John Farrington and Jake Peirson for their guidance and support. Funding for this research was provided by the Education Office of the Woods Hole Oceanographic Institution, the Switzer Foundation, the Ocean Ventures Fund, the Bermuda Biological Station and the National Science Foundation (NSF grants BSR-8919447 \& OCE 8818503). 


\section{TABLE OF CONTENTS}

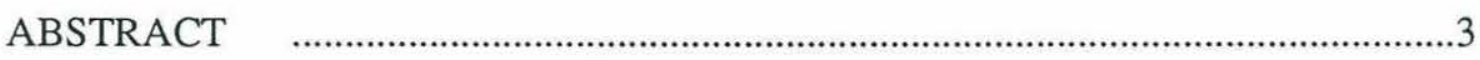

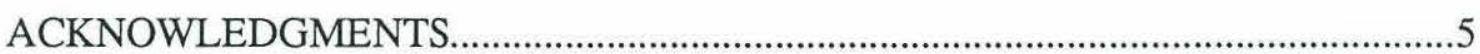

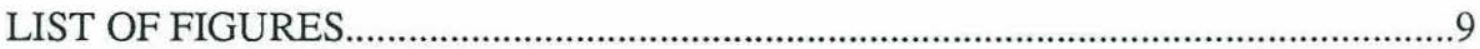

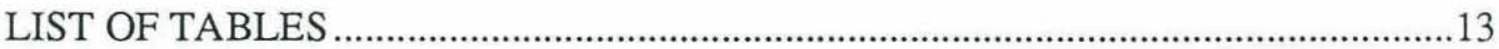

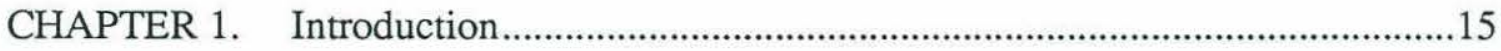

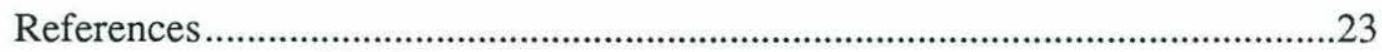

CHAPTER 2. Mixotrophic Nanoplankton in Oligotrophic Surface Waters of the Sargasso Sea May Employ Phagotrophy to Obtain Major Nutrients..........................27

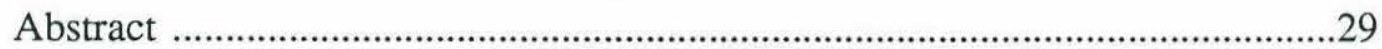

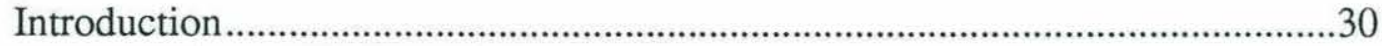

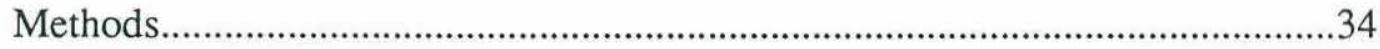

Mixotrophic nanoplankton abundances during August 1989 ...................34

Vertical distribution of mixotrophic nanoplankton during April

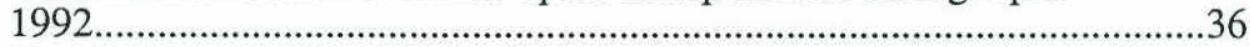

Experimental examination of algal phagotrophy …………………….......37

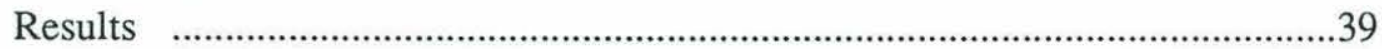

Abundances and vertical distributions of mixotrophic nanoplankton

Microbial population responses to manipulations of light, nutrients, and prey density ..................................................................... 46

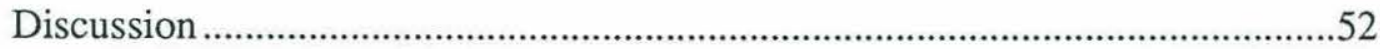

Algal phagotrophy in surface waters of the Sargasso Sea ........................52

Vertical distribution of mixotrophic nanoplankton in euphotic zone waters of the Sargasso Sea...............................................................56

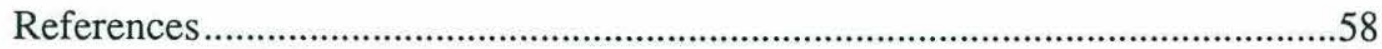

CHAPTER 3. Distribution and Abundance of Mixotrophic Nanoplankton in Nine Adirondack Seepage Ponds and Three Coastal Salt Ponds......................................61

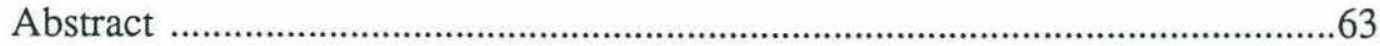

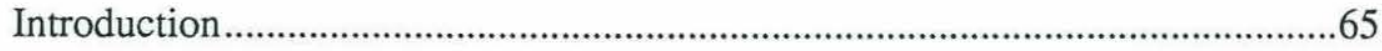

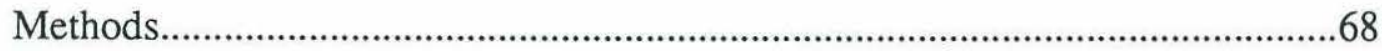

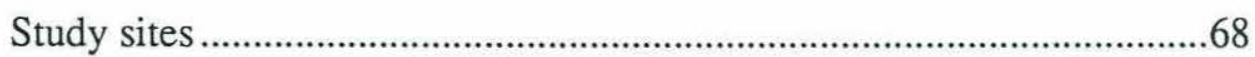

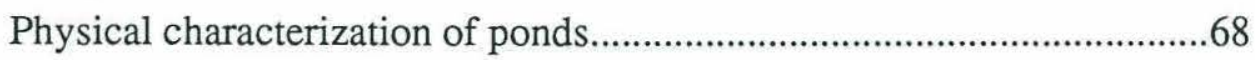

Determination of dissolved oxygen.........................................................69 


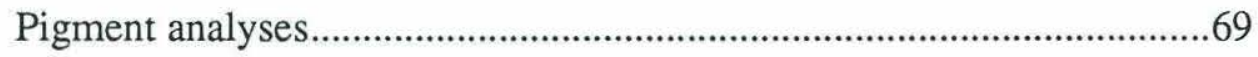

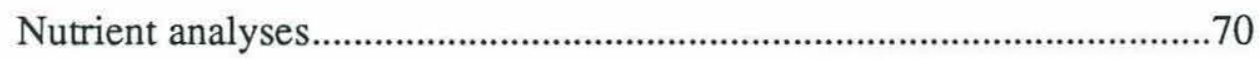

Determination of microbial population abundances .................................71

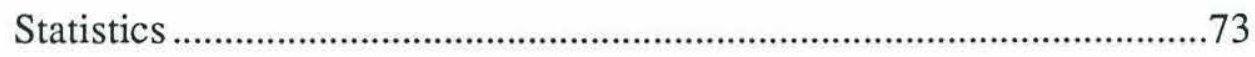

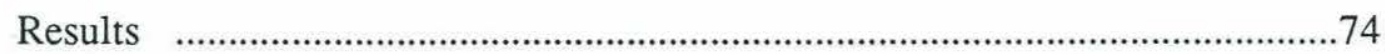

Freshwater Seepage Ponds................................................................

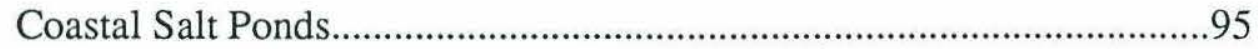

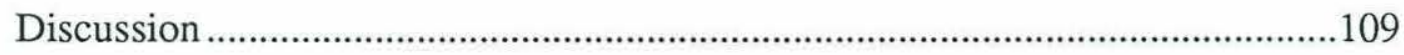

Mixotrophic algae in Adirondack seepage ponds ....................................109

Dinobryon in Wheeler Pond................................................................... 111

Mixotrophy in coastal salt ponds ...........................................................112

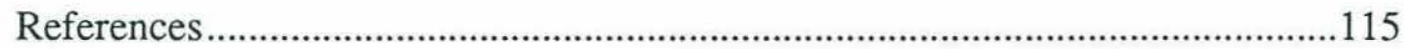

CHAPTER 4. The Importance of Phagotrophy in the Nutrition of Mixotrophic Nanoplankton in an Adirondack Seepage Pond...............................................................121

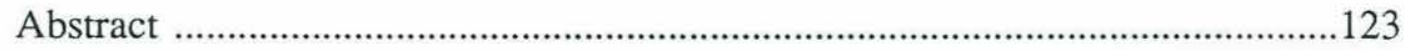

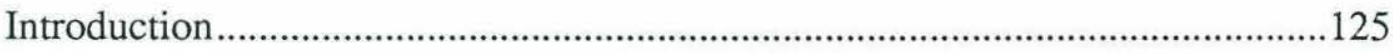

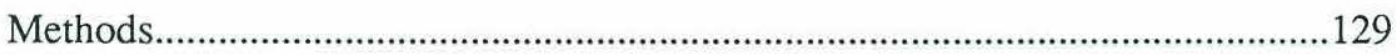

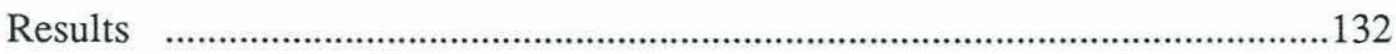

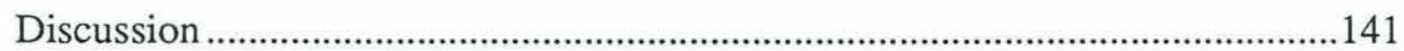

Importance of mixotrophic unidentified solitary and colonial

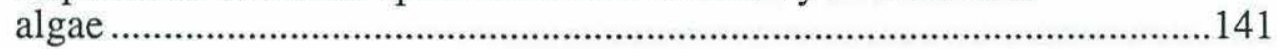

Importance of phagotrophy in the nutrition of Dinobryon..................... 142

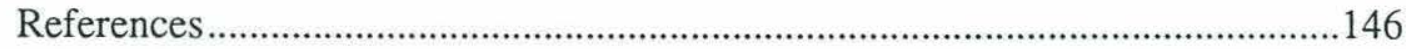

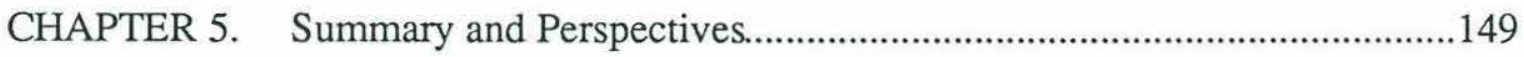

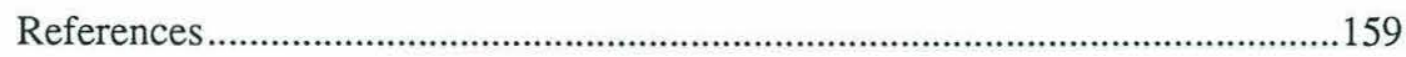

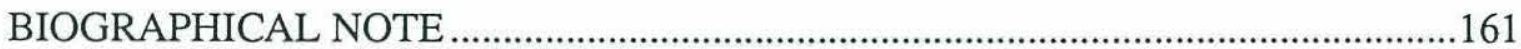




\section{LIST OF FIGURES}

Figure

Page

1.1 Summary of microbial food web trophodynamics

2.1 Vertical profiles of temperature, salinity, beam attenuation and fluorescence in the Sargasso Sea at $25^{\circ} 50^{\prime} \mathrm{N}, 64^{\circ} 30^{\prime} \mathrm{W}$ on 1 April and $30^{\circ} 26^{\prime} \mathrm{N}, 64^{\circ} 30^{\prime} \mathrm{W}$ on 3 April 1992

2.2 Vertical distribution of phototrophic nanoplankton, heterotrophic nanoplankton, chroococcoid cyanobacteria, bacteria and mixotrophic nanoplankton absolute and relative abundance in the Sargasso Sea on 1 April 1992 ....

2.3 Vertical distribution of phototrophic nanoplankton, heterotrophic nanoplankton, chroococcoid cyanobacteria, bacteria and mixotrophic nanoplankton absolute and relative abundance in the Sargasso Sea on 3 April 1992

2.4 Vertical profiles of dissolved inorganic nitrogen and phosphorus concentrations at the Bermuda Atlantic Time Series station at $31^{\circ} \mathrm{N}$, $64^{\circ} \mathrm{W}$ on $18 \mathrm{March}$ and 12 April 1992.

2.5 Mean population abundances of phototrophic and heterotrophic picoplankton and phototrophic, heterotrophic and mixotrophic nanoplankton in all treatments at the end of Experiment I

2.6 Mean population abundances of phototrophic and heterotrophic picoplankton and phototrophic, heterotrophic and mixotrophic nanoplankton in all treatments at the end of Experiment II.....

3.1 Vertical profiles of temperature in nine Adirondack seepage ponds during July 1992

3.2 Vertical profiles of light in nine Adirondack seepage ponds during July 1992

3.3 Vertical profiles of \% oxygen saturation in nine Adirondack seepage ponds during July 1992.

3.4 Vertical profiles of chlorophyll a concentration in nine Adirondack seepage ponds during July 1992.

3.5 Correlations between DOC concentration and epilimnetic concentrations of dissolved $\mathrm{NH}_{4}+, \mathrm{PO}_{4}{ }^{-3}$ and total phosphorus for nine Adirondack seepage ponds during July 1992.

3.6 Vertical profiles of bacterial abundance in nine Adirondack seepage ponds during July 1992 


\section{LIST OF FIGURES (continued)}

Figure

Page

3.7 Correlations between bacterial abundance and temperature, $\%$ of subsurface light and \% oxygen saturation for nine Adirondack seepage ponds during July 1992

3.8 Correlation between bacterial abundance and heterotrophic nanoplankton abundance for nine Adirondack seepage ponds during July 1992

3.9 Vertical profiles of heterotrophic nanoplankton abundance in nine Adirondack seepage ponds during July 1992.

3.10 Correlations between phototrophic nanoplankton abundance and DOC concentration and epilimnetic phototrophic nanoplankton abundance and epilimnetic concentrations of dissolved $\mathrm{NH}_{4}{ }^{+}, \mathrm{PO}_{4}{ }^{-3}$ and total phosphorus for nine Adirondack seepage ponds during July 1992

3.11 Vertical profiles of phototrophic nanoplankton abundance in nine Adirondack seepage ponds during July 1992.

3.12 Vertical profiles of unidentified solitary and colonial phototrophic nanoplankton and Dinobryon abundances in nine Adirondack seepage ponds during July 1992.

3.13 Vertical profiles of the relative abundance of mixotrophic nanoplankton in nine Adirondack seepage ponds during July 1992

3.14 Vertical profiles of unidentified solitary and colonial mixotrophic nanoplankton abundances and abundances of phagotrophically active Dinobryon in nine Adirondack seepage ponds during July 1992.

3.15 Vertical profiles of temperature and salinity in three coastal salt ponds in Falmouth, MA, during early summer 1993

3.16 Vertical profiles of light in three coastal salt ponds in Falmouth, MA, during early summer 1993

3.17 Vertical profiles of \% oxygen saturation in three coastal salt ponds in Falmouth, MA, during early summer 1993.

3.18 Vertical profiles of chlorophyll a and carotenoid concentrations in two coastal salt ponds in Falmouth, MA, during early summer 1993 


\section{LIST OF FIGURES (continued)}

Figure

Page

3.19 Vertical profiles of dissolved inorganic nitrogen and phosphorus concentrations in three coastal salt ponds in Falmouth, MA, during early summer 1993

3.20 Vertical profiles of bacterial abundance and heterotrophic and phototrophic nanoplankton abundances in three coastal salt ponds in Falmouth, MA, during early summer 1993.

3.21 Vertical profiles of mixotrophic nanoplankton absolute and relative abundance in three coastal salt ponds in Falmouth, MA, during early summer 1993

3.22 Vertical distribution and abundance of heterotrophic and mixotrophic ciliates and profiles of temperature, salinity and light attenuation in Salt Pond on 17 July 1993.

4.1 Final population abundances of bacteria and heterotrophic and phototrophic nanoplankton in all treatments.

4.2 Total combined abundance of nanoplanktonic phototrophs from groups that were not phagotrophic and total abundances of Dinobryon and unidentified solitary and colonial nanoplanktonic algae for all treatments on the final day of the experiment.

4.3 Final percentages of phagotrophically active Dinobryon and relative abundances of solitary and colonial nanoplanktonic algae in all treatments

5.1 Hypothetical flow of energy and nutrients through a primarily heterotrophic microbial food chain vs. flow through microbial food chains with mixotrophic nanoplankton or mixotrophic microplankton 


\section{LIST OF TABLES}

Table

Page

2.1 Population abundances of phototrophic and heterotrophic

picoplankton and nanoplankton and the percent of phototrophic

nanoplankton with ingested prey in euphotic zone waters at seven

stations in the Sargasso Sea during 1989.

2.2 Initial and final mean population abundances of phototrophic and heterotrophic picoplankton and phototrophic, heterotrophic and mixotrophic nanoplankton in controls from Experiments I and II

3.1 Freshwater seepage pond and coastal salt pond surface areas, basin depths and dissolved organic carbon concentrations (freshwater ponds only)

3.2 Epilimnetic and hypolimnetic dissolved nutrient concentrations in nine Adirondack seepage ponds during July 1992.

4.1 Initial and final mean population abundances of bacteria and heterotrophic and phototrophic nanoplankton in controls.

4.2 Initial and final percentages of phagotrophically active Dinobryon and relative abundances of unidentified solitary and colonial mixotrophic nanoplankton in controls.

5.1 Abundances of mixotrophic nanoplankton in marine and freshwater plankton communities 
CHAPTER 1

Introduction 


\section{INTRODUCTION}

Over the last two decades we have seen the emergence of a new paradigm of the planktonic food web (Pomeroy, 1974). The new paradigm recognizes a much larger role for minute algae in primary production than was previously thought, and includes an extension of the classical paradigm now known as the microbial food loop. The microbial loop incorporates microheterotrophic processes into the classical food web and is considered important in the cycling of energy and nutrients in planktonic ecosystems. It has become customary to summarize the trophodynamics in the microbial food web by clear distinctions between phototrophy and heterotrophy, and size-dependent predatorprey relationships (Fig. 1.1). Picoplanktonic and nanoplanktonic phototrophs (prokaryotic and eukaryotic algae $0.2-2 \mu \mathrm{m}$ and $2-20 \mu \mathrm{m}$ in size, respectively) are now known to dominate the phytoplankton assemblage in many aquatic environments (Ilmavirta, 1982; Davis \& Sieburth, 1984; Estep et al., 1984; Davis et al., 1985), and they are believed to account for a significant fraction of primary production (Malone, 1971; McCarthy et al., 1974; Larsson \& Hagström, 1982; Hagström et al., 1983; Hannah \& Boney, 1983; Joint et al., 1986). It is now believed that as much as $50 \%$ of primary production is consumed by picoplanktonic heterotrophs (bacteria $0.2-2 \mu \mathrm{m}$ in size), and that a large fraction of this production is converted into bacterial biomass rather than remineralized by the bacteria (Sorokin, 1971; Pomeroy, 1974; Sieburth et al., 1977; Larsson \& Hagström, 1979; Fuhrman \& Azam, 1980; Williams, 1981; Azam et al., 1983). Nanoplankton-sized $(2-20 \mu \mathrm{m})$ heterotrophic protists (flagellates and ciliates) are believed to be the major consumers of bacterial production (Sieburth, 1979; Sorokin, 1979; Fenchel, 1982c), and are thought to be responsible for much of the remineralization and recycling of essential nutrients for phytoplankton and bacteria (Azam et al., 1983; Caron, 1984; Caron \& Goldman, 1990). These nanoplanktonic bacterivores are grazed by larger protists which, in turn, may be consumed by larger 


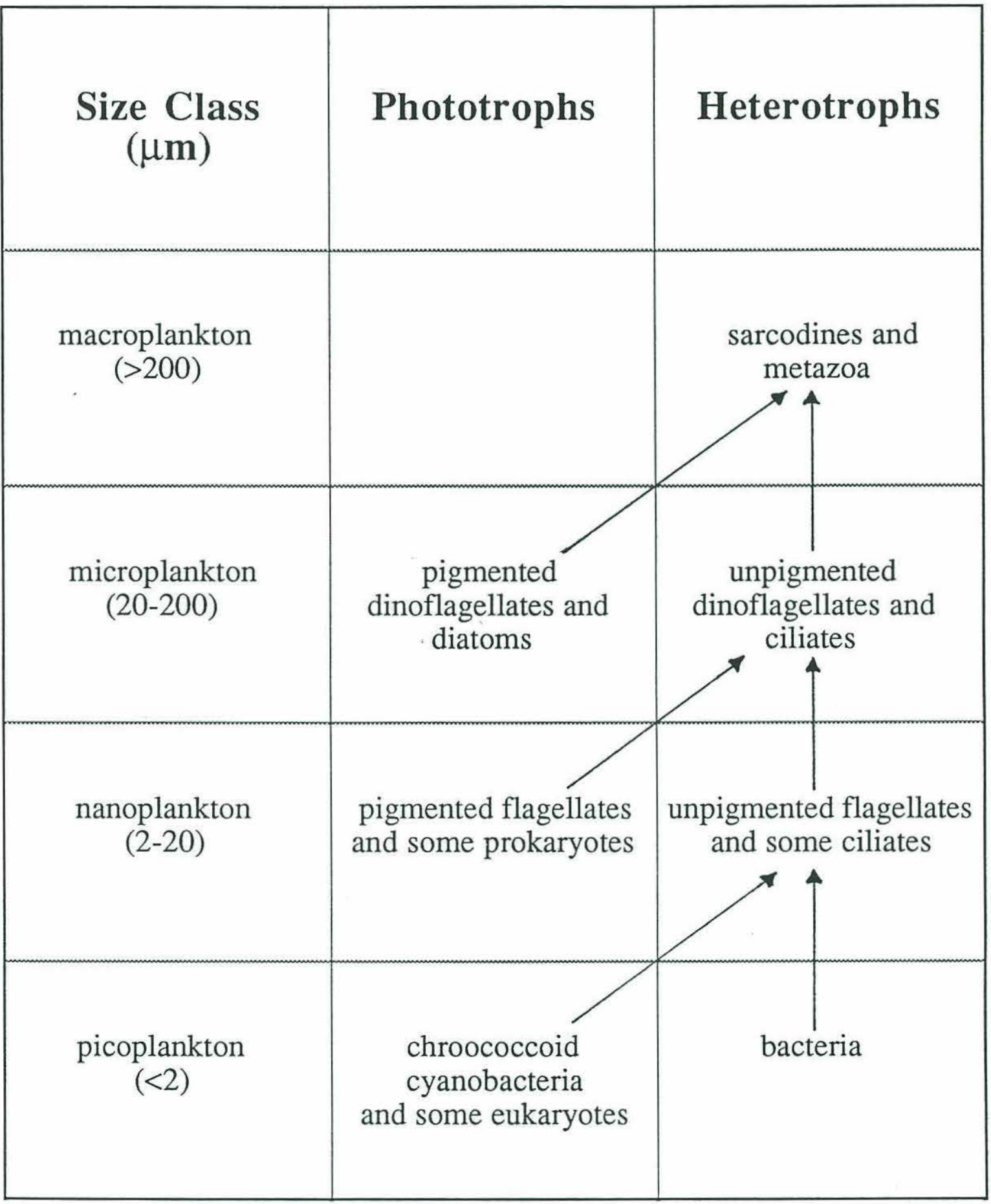

Figure 1.1. Summary of microbial food web trophic relationships as defined by size class and nutritional mode. 
zooplankton thereby returning some fraction of the energy and nutrients from bacteria to the classical food web via flow through the microbial loop (Sherr \& Sherr, 1984; Caron, 1991).

This modern view of microbial trophodynamics has provided a basis for better understanding energy and nutrient flow in planktonic systems. However, shortcomings associated with an approach that makes clear distinctions between phototrophy and heterotrophy have become apparent. In particular, it has become increasingly evident that many protists are capable of functioning at more than one trophic level. The rapid differentiation of phototrophic and heterotrophic plankton based on the presence or absence of plastids (Porter \& Feig, 1980; Caron, 1983; Sherr \& Sherr, 1983; Sherr et al., 1993) has yielded useful information on the phototrophic abilities of protists, but new methods (Borsheim, 1984; Cynar \& Sieburth, 1986; Wikner et al., 1986; Sherr et al., 1987) have resulted in the discovery (or rediscovery) of planktonic protists that are capable of phagotrophy in addition to photosynthesis, and thus, function at more than one trophic level. Mixotrophy refers to the ability of these organisms to combine phototrophy with phagotrophy to satisfy nutritional requirements for growth and/or survival (Sanders, 1991).

The Sarcodinia and Ciliophora are examples of protistan taxa that have generally been considered to be heterotrophic. It is now known that some sarcodines and ciliates contain highly modified endosymbiotic algae that allow them to function primarily as autotrophs, while other species of sarcodines and ciliates are mixotrophic (Laval-Peuto \& Brownlee, 1986; Laval-Peuto et al., 1986; Patterson \& Dürrschmidt, 1987; LavalPeuto \& Rassoulzadegan, 1988; Stoecker et al., 1988; Rogerson et al., 1989; Stoecker et al., 1989b). These latter mixotrophic species appear to sequester chloroplasts after ingesting algal prey. The chloroplasts, which remain functional once inside the cells, allow the protists to function both phototrophically and phagotrophically (Lopez, 1979; Stoecker et al., 1987; Lee et al., 1988). 
In addition, numerous species of plastidic flagellates from diverse taxa (Chrysophyceae, Prymnesiophyceae, Cryptophyceae and Dinophyceae) have been found to be capable of particle ingestion (for summary of references see Sanders \& Porter, 1988). The ability of algae to consume particulate organic material (usually bacteria and other small unicellular organisms) has been known for nearly a century. Until recently though, the ecological implications of this behavior have been largely ignored. Algal phagotrophy has gained renewed interest with recognition of the importance of microheterotrophic processes in planktonic food webs (Williams, 1981; Azam et al., 1983) and methodological developments in the area of microbial ecology that allow direct differentiation of heterotrophic (apochlorotic) protists and phagocytic or nonphagocytic plastidic protists in natural samples.

Some investigations have focused on individual mixotrophic species to determine the role of phagotrophy in their nutrition. These investigations have provided information to suggest that phagotrophy may play a variety of roles, including the acquisition of carbon, major nutrients (nitrogen and phosphorus) or specific growth factors such as vitamins or essential lipids (Kimura \& Ishida, 1989; Sanders et al., 1990; Caron et al., 1992; Nygaard \& Tobiesen, 1993). Species that are capable of acquiring carbon via phagotrophy may experience a selective advantage over purely phototrophic algae in light limiting conditions, while acquisition of major nutrients $(\mathrm{N}$ or $\mathrm{P})$ may be particularly advantageous to algae in oligotrophic environments.

Mixotrophic algae have been found to dominate the nanoplankton assemblage in some aquatic environments, and it is clear from a few field studies that algal phagotrophy can occasionally contribute significantly to total bacterivory (Bird \& Kalff, 1986; Porter, 1988; Bird \& Kalff, 1989; Sanders et al., 1989; Berninger et al., 1992). Nevertheless, the distribution and abundance of mixotrophic algae have not been widely characterized in aquatic environments, and the factors that control their abundances in these environments are poorly understood. As a consequence, the ecological importance 
of mixotrophy in the flow of energy and nutrients through planktonic food webs remains unclear.

The purpose of this dissertation was to further our understanding of the importance of nanoplanktonic mixotrophic algae in aquatic ecosystems and to attempt to determine what factors influence their phagotrophic behavior in these environments. The dissertation is composed of 3 manuscripts which examine the relationships between the distribution and abundance of mixotrophic algae and physical, chemical and biological parameters that may influence their abundance and phagotrophic activity in marine and freshwater plankton communities. The vertical distribution and abundance of mixotrophic nanoplankton at several stations in the Sargasso Sea, south of Bermuda, and the importance of phagotrophy in the nutrition of mixotrophic algae in surface waters is discussed based on the results of experimental manipulations are described in Chapter 2. Information on the density of picoplanktonic and nanoplanktonic phototrophs and heterotrophs throughout the euphotic zone at each station is also provided in this chapter.

Relationships between the abundance of mixotrophic algae and physical, chemical and biological parameters in a series of seepage ponds located in the Adirondack Mountains of New York and in a group of coastal salt ponds located in Falmouth, Massachusetts are examined in Chapter 3. The vertical distributions and abundances of mixotrophic algae are determined and their contribution to the total phototrophic nanoplankton is presented. Densities of heterotrophic bacteria and nanoplankton are also considered in relation to the abundance of mixotrophic algae. In addition, the contribution of mixotrophic ("green") ciliates to ciliate populations in one coastal salt pond are discussed.

Finally, a study conducted in one of the Adirondack seepage ponds examined in the previous chapter is discribed in Chapter 4. Mixotrophic algae were found to be relatively abundant in the epilimnion of this pond. An experiment to determine the 
factors that may control the abundance or phagotrophic activity of mixotrophic algae in this pond are discussed in Chapter 3. Specifically, the influence of light, major nutrients ( $\mathrm{N}$ and $\mathrm{P}$ ) and prey density on the phagotrophic activity of an abundant mixotrophic chrysophyte, Dinobryon along with other solitary and colonial mixotrophic nanoplankton was examined.

The results from these studies indicate that mixotrophic nanoplankton can be numerically important in some aquatic environments. In addition, field experiments reported on in Chapters 2 and 4 provide the first evidence from the field to suggest that mixotrophic nanoplankton obtain major nutrients $(\mathrm{N}$ and $\mathrm{P})$ by consuming bacteria. 


\section{REFERENCES}

Azam, F., Fenchel, T., Field, J. G., Gray, J. S., Meyer-Reil, L. A. \& Thingstad, F. 1983 The ecological role of water-column microbes in the sea. Marine Ecology Progress Series 10, 257-263

Berninger, U.-G., Caron, D. A. \& Sanders, R. W. 1992 Mixotrophic algae in three icecovered lakes of the Pocono Mountains, U.S.A. Freshwater Biology 28, 263-272

Bird, D. F. \& Kalff, J. 1986 Bacterial grazing by planktonic lake algae. Science 231, 493-495

Bird, D. F. \& Kalff, J. 1989 Phagotrophic sustenance of a metalimnetic phytoplankton peak. Limnology and Oceanography 34, 155-162

Borsheim, K. Y. 1984 Clearance rates of bacteria-sized particles by freshwater ciliates, measured with monodispersed fluorescent latex beads. Oecologia 63, 286-288

Caron, D. A. 1983 Technique for enumeration of heterotrophic and phototrophic nanoplankton, using epifluorescence microscopy, and comparison with other procedures. Applied and Environmental Microbiology 46, 491-498

Caron, D. A. 1984 The role of heterotrophic microflagellates in plankton communities. Ph.D. thesis, Woods Hole Oceanographic Institution and Massachusetts Institute of Technology, WHOI-84-35.

Caron, D. A. 1991 Evolving role of protozoa in aquatic nutrient cycles. In Protozoa and their role in marine processes vol. 25 (Reid, P. C., Turley, C. M. \& Burkill, P. H., eds.). Springer-Verlag, Berlin. pp. 387-415.

Caron, D. A. \& Goldman, J. C. 1990 Protozoan nutrient regeneration. In Ecology of marine protozoa (Capriulo, G. M., eds.). Oxford University Press, New York. pp. 283306.

Caron, D. A., Sanders, R. W., Lim, E. L., Marrasé, C., Amaral, L. A., Whitney, S., Aoki, R. B. \& Porter, K. G. 1992 Light-dependent phagotrophy in the freshwater mixotrophic chrysophyte Dinobryon cylindricum. Microbial Ecology 25, 93-111

Cynar, F. J. \& Sieburth, J. M. 1986 Unambiguous detection and improved quantification of phagotrophy in apochlorotic nanoflagellates using fluorescent microspheres and concomitant phase contrast and epifluorescence microscopy. Marine Ecology Progress Series 32, 61-70

Davis, P. G., Caron, D. A., Johnson, P. W. \& Sieburth, J. M. 1985 Phototrophic and apochlorotic components of picoplankton and nanoplankton in the North Atlantic: geographic, vertical seasonal and diel distributions. Marine Ecology Progress Series 21,

Davis, P. G. \& Sieburth, J. M. 1984 Differentiation and characterization of individual phototrophic and heterotrophic microflagellates by sequential epifluorescence and electron microscopy. Transactions of the American Microscopical Society 103, 221-227 
Estep, K. W., Davis, P. G., Hargraves, P. E. \& Sieburth, J. M. 1984 Chloroplast containing microflagellates in natural populations of North Atlantic nanoplankton, their identification and distribution; including a description of five new species of Chrysochromulina (Prymnesiophyceae). Protistologia 20, 613-634

Fenchel, T. 1982 Ecology of heterotrophic microflagellates. IV. Quantitative occurrence and importance as bacterial consumers. Marine Ecology Progress Series 9, $35-42$

Fuhrman, J. A. \& Azam, F. 1980 Bacterioplankton secondary production estimates for coastal waters of British Columbia, Antarctica, and California. Applied and Environmental Microbiology 39, 1085-1095

Hagström, Å., Andersson, A. \& Öquist, G. 1983 Algal and bacterial production in a coastal area (Norrbyn) of the Bothnian Sea. Aquilo Ser Zool 22, 131-137

Hannah, F. J. \& Boney, A. D. 1983 Nanophytoplankton in the firth of Clyde, Scotland: seasonal abundance, carbon fixation and species composition. Journal of Experimental Marine Biology and Ecology 67, 105-147

Ilmavirta, V. 1982 Dynamics of phytoplankton in Finnish Lakes. Hydrobiologia 86, $11-20$

Joint, I. R., Owens, N. J. P. \& Pomeroy, A. J. 1986 Seasonal production of photosynthetic picoplankton and nanoplankton in the Celtic Sea. Marine Ecology Progress Series 28, 251-258

Kimura, B. \& Ishida, Y. 1989 Phospholipid as a growth factor of Uroglena americana, a red tide Chrysophyceae in Lake Biwa. Nippon Suisan Gakkaishi 55, 799-804

Larsson, U. \& Hagström, ^. 1979 Phytoplankton exudate release as an energy source for the growth of pelagic bacteria. Marine Biology 52, 199-206

Larsson, U. \& Hagström, ^. 1982 Fractionated phytoplankton primary production, exude release and bacterial production in a Baltic eutrophication gradient. Marine Biology 67, 57-70

Laval-Peuto, M. \& Brownlee, D. C. 1986 Identification and systematics of the Tintinnina (Ciliophora): evaluation and suggestions for improvement. Annales de L'institut Océanographique 62, 69-84

Laval-Peuto, M. \& Rassoulzadegan, F. 1988 Autofluorescence of marine planktonic Oligotrichina and other ciliates. Hydrobiologia 159, 99-110

Laval-Peuto, M., Slavano, P., Gayol, P. \& Greuet, C. 1986 Mixotrophy in marine planktonic ciliates: ultrastructural study of Tontonia appendiculariformis (Ciliophora, Oligotrichina). Marine Microbial Food Webs 1, 81-104

Lee, J. J., Lanners, E. \& Ter Kuile, B. 1988 The retention of chloroplasts by the foraminifer Elphidium crispum. Symbiosis 5, 45-60

Lopez, E. 1979 Algal chloroplasts in the protoplasm of three species of benthic foraminifera: taxonomic affinity, viability and persistence. Mar. Biol. 53, 201-211 
Malone, T. C. 1971 The relative importance of nannoplankton and netplankton as primary producers in tropical oceanic and neritic phytoplankton communities.

Limnology and Oceanography 16, 633-639

McCarthy, J. J., Taylor, W. R. \& Loftus, M. E. 1974 Significance of nanoplankton in the Chesapeake Bay estuary and problems associated with the measurement of nanoplankton productivity. Marine Biology 24, 7-16

Nygaard, K. \& Tobiesen, A. 1993 Bacterivory in algae: A survival strategy during nutrient limitation. Limnology and Oceanography 38, 273-279

Patterson, D. J. \& Dürrschmidt, M. 1987 Selective retention of chloroplasts by algivorous Heliozoa: fortuitous chloroplast symbiosis? European Journal of Protistology 23, 51-55

Pomeroy, L. R. 1974 The ocean's food web, a changing paradigm. Bioscience 24, 499-504

Porter, K. G. 1988 Phagotrophic phytoflagellates in microbial food webs. Hydrobiologia 159, 89-97

Porter, K. G. \& Feig, Y. S. 1980 The use of DAPI for identifying and counting aquatic microflora. Limnology and Oceanography 25, 943-948

Rogerson, A., Finlay, B. J. \& Berninger, U.-G. 1989 Sequestered chloroplasts in the freshwater ciliate Strombidium viride (Ciliophora: Oligotrichida). Trans. Am. Microsc. Soc. 108, 117-126

Sanders, R. W. 1991 Mixotrophic protists in marine and freshwater ecosystems. Journal of Protozoology 38, 76-81

Sanders, R. W. \& Porter, K. G. 1988 Phagotrophic phytoflagellates. Advances in Microbial Ecology 10, 167-192

Sanders, R. W., Porter, K. G., Bennett, S. J. \& DeBiase, A. E. 1989 Seasonal patterns of bacterivory by flagellates, ciliates, rotifers, and cladocerans in a freshwater planktonic community. Limnology and Oceanography 34, 673-687

Sanders, R. W., Porter, K. G. \& Caron, D. A. 1990 Relationship between phototrophy and phagotrophy in the mixotrophic chrysophyte Poterioochromonas malhamensis.

Microbial Ecology 19, 97-109

Sherr, B. \& Sherr, E. 1983 Enumeration of heterotrophic microprotozoa by epifluorescence microscopy. Estuarine and Coastal Shelf Science 16, 1-17

Sherr, B. F. \& Sherr, E. B. 1984 Role of heterotrophic protozoa in carbon and energy flow in aquatic ecosystems. In Current Perspectives in Microbial Ecology (Klug, M. J. \& Reddy, C. A., eds.). American Society of Microbiology, Washington, DC. pp. 412423.

Sherr, B. F., Sherr, E. B. \& Fallon, R. D. 1987 Use of monodispersed, fluorescently labeled bacteria to estimate in situ protozoan bacterivory. Applied and Environmental Microbiology 53, 958-965 
Sherr, E. B., Caron, D. A. \& Sherr, B. F. 1993 Staining of heterotrophic protists for visualization via epifluorescence microscopy. In Current Methods in Aquatic Microbial Ecology (Kemp, P., Cole, J., Sherr, B. \& Sherr, E., eds.). Lewis Publishers, pp. 213228.

Sieburth, J. M. 1979 Sea Microbes. Oxford University Press, New York.

Sieburth, J. M., Johnson, K. M., Burney, C. M. \& Lavoie, D. M. 1977 Estimation of in situ rates of heterotrophy using diurnal changes in dissolved organic matter and growth rates of picoplankton in diffusion culture. Helgolander wiss. Meeresunters. 30, 565-574

Sorokin, J. I. 1971 On the role of bacteria in the productivity of tropical oceanic waters. Int. Revue ges. Hydrobiol. 56, 1-48

Sorokin, Y. I. 1979 Zooflagellates as a component of eutrophic and oligotrophic communities of the Pacific Ocean. Okeanologiya SSSR 3, 476-480

Stoecker, D., Michaels, A. E. \& Davis, L. H. 1987 Large proportion of marine planktonic ciliates found to contain functional chloroplasts. Nature 326, 790-792

Stoecker, D. K., Silver, M. W., Michaels, A. E. \& Davis, L. H. 1988 Obligate mixotrophy in Laboea strobila, a ciliate which retains chloroplasts. Marine Biology 99, $415-423$

Stoecker, D. K., Silver, M. W., Michaels, A. E. \& Davis, L. H. 1989 Enslavement of algal chloroplasts by four Strombidium spp. (Ciliophora, Oligotrichida). Marine Microbial Food Webs 3, 79-100

Wikner, J., Andersson, A., Normark, S. \& Hagström, Å. 1986 Use of genetically marked minicells as a probe in measurement of predation on bacteria in aquatic environments. Applied and Environmental Microbiology 52, 4-8

Williams, P. J. 1. 1981 Incorporation of microheterotrophic processes into the classical paradigm of the planktonic food web. Kieler Meeresforsch. 5, 1-28 


\section{CHAPTER 2}

Mixotrophic Nanoplankton in Oligotrophic Surface Waters of the Sargasso Sea May Employ Phagotrophy to Obtain Major Nutrients 


\begin{abstract}
The vertical distribution and abundance of mixotrophic nanoplankton was examined in an oligotrophic open ocean plankton community. Fluorescently labeled bacteria and cyanobacteria were used as tracers of ingestion in experiments designed to determine abundances of mixotrophic nanoplankton during two cruises to the Sargasso Sea south of Bermuda. Phagotrophic nanoplanktonic $(2-20 \mu \mathrm{m})$ algae ranged from undetectable to more than $100 \mathrm{ml}^{-1}$, and were more abundant near the surface (up to 140 $\mathrm{ml}^{-1}$ ) than in the deeper euphotic zone. On two occasions $50 \%$ of the phototrophic nanoplankton in surface waters were observed with ingested fluorescent tracers. The contribution of mixotrophic algae to the total phototrophic nanoplankton assemblage in the deep chlorophyll maximum, however, did not exceed $0.5 \%$. It is possible that mixotrophic algae were more abundant in the DCM, but were not phagotrophically active.
\end{abstract}

Two four-day experimental incubations were subsequently carried out to determine the adaptive significance of phagotrophic behavior for algae in surface waters of the Sargasso Sea. Experiments were designed to examine the influence of light, nutrients and prey density on the phagotrophic behavior of mixotrophic nanoplankton. Greater mixotrophic nanoplankton abundances were observed in treatments that received no nutrient inputs and were limited by the availability of inorganic nutrients during the experiments. A decrease in the abundance of mixotrophic algae or a decrease in their phagotrophic activity occurred with nutrient enrichment. Based on the experimental results we suggest that phagotrophy was a mechanism by which these algae supplemented nutrient acquisition during periods of low dissolved nutrient concentrations. Higher abundances of mixotrophic nanoplankton observed in the upper $50 \mathrm{~m}$ of the Sargasso Sea may have been due to the generally low nutrient concentrations in these waters. 


\section{INTRODUCTION}

Mixotrophic algae are algae that combine autotrophic and heterotrophic modes of nutrition. In many microalgae this trophic behavior is characterized by a combination of photosynthesis and the ingestion and digestion of preformed organic material (usually bacteria and other small unicellular microorganisms; Fenchel, 1982b; Sanders \& Porter, 1988; Andersson et al., 1989; Caron et al., 1990; Sanders et al., 1990; Sanders, 1991). The ability to ingest particulate material by unicellular algae has been known for many years (Pascher, 1911; Pringsheim, 1952; Pringsheim, 1955). Only recently, though, have ecologists begun to recognize the potential significance of this behavior for algal growth and survival, and elemental flow through aquatic food webs (Bird \& Kalff, 1989).

Phagotrophic activity by algae has important implications for algal growth and survival. Phagotrophy may serve as a mechanism for obtaining carbon, major nutrients (nitrogen or phosphorus) or specific growth factors that may be necessary to satisfy the nutritional requirements of the algae. Some facultative mixotrophic species, or amphitrophs (Schnepf \& Elbrächter, 1992) are primarily heterotrophic and rely on phagotrophy to obtain most or all of the organic carbon used for metabolism and growth. Photosynthesis in these species appears to be used as a mechanism for survival only under poor heterotrophic conditions (i.e., low prey abundance). For example, phagotrophy was found to be the dominant source of nutrition in the freshwater chrysophyte Poterioochromonas malhamensis (Caron et al., 1990; Sanders et al., 1990; Lewitus \& Caron, 1991). This alga ingested prey and grew rapidly in a range of light regimes, including continuous darkness if bacteria were present in the culture medium in sufficient numbers. When bacterial abundances were reduced below a grazing threshold

of $10^{6}$ bacteria $\mathrm{ml}^{-1}$, however, the alga's growth rate slowed considerably, but continued at a very slow rate provided there was adequate light for photosynthesis. Similar 
patterns of grazing, photosynthesis and growth have been observed in some species of Ochromonas (Fenchel, 1982a; Andersson et al., 1989).

Other species may be obligate mixotrophs that require both photosynthesis and phagotrophy to sustain growth of the algae. In these species phagotrophy may play a different role. For example, it has been suggested that phagotrophy may be employed by some algae to acquire specific growth factors (i.e. vitamins, lipids) required for phototrophic growth. While phycologists have used the term "auxotroph" to refer to algal species with specific organic requirements (Morris, 1980) phagotrophy as a mechanism for obtaining those growth factors has been demonstrated in few instances. Kimura and Ishida (1986) demonstrated that phagotrophic behavior by the mixotrophic freshwater red tide chrysophyte Uroglena americana was necessary to sustain growth of the alga. Laboratory studies with $U$. americana revealed that bacteria provided a specific phospholipid that the algae were unable to synthesize (Kimura \& Ishida, 1989). Acquisition of a growth factor has also been suggested as one possible explanation for phagotrophic activity in another freshwater chrysophyte, Dinobryon cylindricum (Caron et al., 1992).

Phagotrophy may also be used by some mixotrophic algae to acquire major nutrients (nitrogen and phosphorus). There are very few laboratory data to support this hypothesis, however (Veen, 1991; Nygaard \& Tobiesen, 1993). Photosynthesis would presumably be the primary energy source for these mixotrophs while phagotrophy would allow these algae to successfully compete with non-phagotrophic algae (and bacteria) for growth-limiting nutrients. Such a strategy for growth might be particularly useful in well-lighted oligotrophic waters.

While the examples given above indicate that phagotrophic behavior may provide mixotrophic algae with a considerable selective advantage over non-mixotrophic species, relatively few data actually exist on the abundance or activity of mixotrophic species in nature. A few studies have demonstrated that mixotrophic algae are abundant 
in freshwater environments and occasionally comprise a large percentage of the phytoplankton community. Bird and Kalff (1989) reported that mixotrophic algae were responsible for sustenance of a metalimnetic phytoplankton peak in Lac Gilbert, Quebec. They determined that phagotrophy might have accounted for nearly $80 \%$ of the algal community carbon assimilation in this peak on an overcast day. Berninger et al. (1992) found that over-wintering phytoplankton populations in a Pennsylvanian lake were dominated by mixotrophic (phagotrophic) chrysophyte algae. These species were also common in the phytoplankton bloom that takes place in the lake at the time of ice-out (Siver \& Chock, 1986). Berninger et al. (1992) suggested that the inoculum for the bloom may be maintained, in part, by phagotrophy of these algae under the ice.

Several species of mixotrophic algae have been observed and/or cultured from oceanic environments (Fenchel, 1982a; Estep et al., 1986; Andersson et al., 1989; Nygaard \& Hessen, 1990; Bockstahler \& Coats, 1993) but the overall importance of mixotrophic algae in marine plankton communities remains unclear. The use of phagotrophy to acquire major nutrients has been proposed for some marine species of mixotrophic algae. Over the past several years, toxic blooms of algal flagellates occurred in the coastal waters of Norway. These blooms were associated with low inorganic phosphate concentrations in the water column (Dahl et al., 1989). Interestingly, the blooms were dominated by algal flagellates capable of phagotrophy (Børsheim et al., 1989; Johnsen \& Lein, 1989). Nygaard and Tobiesen (1993) examined bacterivory by several species of these marine mixotrophic flagellates in P-limited and non-limited cultures. Based on experiments performed in the laboratory, they hypothesized that phagotrophic behavior may permit these species to form blooms when phosphate becomes limiting to other algae.

The present study was designed to determine the abundance of mixotrophic algae in an oligotrophic open ocean plankton community and to examine experimentally the influence of light, nutrients and prey density on their phagotrophic behavior. Analyses 
of water samples collected in the euphotic zone of the Sargasso Sea during a cruise in August 1989 demonstrated the presence of significant but variable numbers of nanoplanktonic mixotrophs. A more detailed examination of the vertical distribution of mixotrophic nanoplankton (MNAN) conducted in early April 1992 yielded a range in abundances of mixotrophs from $<1 \mathrm{MNAN} \mathrm{m}^{-1}$ just below the deep chlorophyll maximum to greater than $30 \mathrm{MNAN} \mathrm{ml}^{-1}$ near the surface. Experiments conducted to examine the reasons for phagotrophic activity by algae in surface waters during this study support the hypothesis that mixotrophic algae in surface waters of this oligotrophic oceanic system were ingesting bacteria in response to nutrient stress. 


\section{METHODS}

Mixotrophic nanoplankton abundances during August 1989

Estimates of mixotrophic nanoplankton abundances in euphotic zone waters of the Sargasso Sea were obtained in August 1989 as a part of the ZOOSWAT program (R/V Gyre). These measurements were obtained during experiments designed to estimate the ingestion rates of phagotrophic protists $(<20 \mu \mathrm{m}$ in size) using the FLB uptake method (Sherr et al., 1987). Samples were collected in $0.1 \mathrm{~N} \mathrm{HCl-rinsed} \mathrm{Niskin}$ bottles from two depths at seven closely spaced stations during August 1989 south of Bermuda $\left(28-32^{\circ} \mathrm{N}, 63-78^{\circ} \mathrm{W}\right)$. Water samples were collected from a depth between 1 and $5 \mathrm{~m}$ (surface) and from a depth coincident with the deep chlorophyll maximum (DCM) as determined by in situ fluorometry using a CTD-fluorescence instrument package attached to a Niskin rosette sampler. Subsamples were removed and preserved immediately with gluteraldehyde at a final concentration of $1 \%$ for microscopic determination of bacteria and chroococcoid cyanobacteria abundances $(<2 \mu \mathrm{m})$, and phototrophic and heterotrophic nanoplankton abundances (microalgae and protozoa 2-20

$\mu \mathrm{m}$ in size, respectively). All population counts were performed by epifluorescence microscopy at 1000x magnification (Porter \& Feig, 1980; Caron, 1983; Waterbury et al., 1987; Sherr et al., 1993).

Grazing experiments were conducted using fluorescently labeled cultured microorganisms as tracers of natural prey that were prepared according to methods outlined in Sherr et al. (1987). Grazing experiments were conducted using fluorescently labeled cultured microorganisms as tracers of natural prey (Sherr et al., 1987). Fluorescently labeled cyanobacteria (Synechococcus sp., clone WH8012) were used extensively in these experiments. This cyanobacterium maintains a small size $(\sim 0.8-0.9$ $\mu \mathrm{m}$ in diameter) when grown in laboratory cultures and thus is representative of the size 
of naturally occurring cyanobacteria and some heterotrophic bacteria. Fluorescently labeled minicells (FLM) of the bacterium Escherichia coli were also used (Pace et al., 1990), but the usefulness of FLM for examining protistan ingestion was compromised by clumping and fading of these cells.

One liter subsamples from each depth were placed in $1.2 \mathrm{~L}$ clear polycarbonate vessels and inoculated with fluorescently labeled prey within one hour of collection. Immediately after the addition of fluorescently labeled prey the containers were gently swirled to distribute the tracer, and samples were removed and preserved to establish the initial numbers of labeled prey and to provide a "time zero" sample for examining ingestion. The abundances of labeled prey used in these experiments were chosen such that they could be readily counted, but did not dramatically increase the abundance of natural prey of the same size (generally $10-30 \%$ of the natural prey abundance). Incubations were conducted in duplicate in an on-deck Plexiglas incubator. Seawater was continuously pumped through the incubator to maintain the water temperature at ambient surface water temperature. Light intensity was attenuated to the approximate intensities at the two sampling depths using neutral density screening. After 24 hours of incubation a second set of samples was removed and preserved to establish the abundance of mixotrophic nanoplankton.

More than 400 individual phototrophic nanoplankton (chloroplast-bearing cells 2-20 $\mu \mathrm{m}$ in size) in each sample were observed for ingested fluorescently labeled prey as they were encountered during the microscopical examinations. Mixotrophic nanoplankton (MNAN) were operationally defined as cells containing autofluorescent chloroplasts and ingested fluorescently labeled prey. The relative abundance of mixotrophic nanoplankton was determined as a percentage of the phototrophic nanoplankton. The percentages were then converted to absolute abundances of mixotrophic nanoplankton based on the abundances of phototrophic nanoplankton in the samples. This method for determining the abundances of mixotrophic nanoplankton is 
based on two assumptions: (1) fluorescently labeled prey are ingested at the same rate as natural prey, and (2) all MNAN actively phagocytize prey during experiments. This method therefore provides a lower limit estimate of the actual abundances of mixotrophic nanoplankton present in a water sample because some mixotrophic cells may not phagocytize prey during experiments. While these latter mixotrophic individuals will be undetected by this method, at present, there is no other way to establish the presence of mixotrophs in natural samples.

Vertical distribution of mixotrophic nanoplankton during April 1992

Vertical profiles of mixotrophic nanoplankton abundance were determined at two stations south of Bermuda in the Sargasso Sea at $25^{\circ} 59^{\prime} \mathrm{N}, 64^{\circ} 30^{\prime} \mathrm{W}$ on April 1 and $30^{\circ} 26^{\prime} \mathrm{N}, 64^{\circ} 30^{\prime} \mathrm{W}$ on April 3, 1992 during R/V Endeavor cruise leg 234. Samples were collected as described above from five depths including the surface mixed layer and deep chlorophyll maximum. Duplicate $1 \mathrm{~L}$ subsamples from each depth were prepared and incubated as described. Fluorescently labeled bacteria (FLB) were prepared from cultures of Pseudomonas halodurans ( $\sim 0.8-1.0 \mu \mathrm{m}$ average cell size) according to the method of Sherr et al. (1987) and used as prey. FLB were added to samples at 30 to 50 percent of the natural prey abundance. The samples were incubated as described above for 6 hours starting in late afternoon. Subsamples were removed prior to incubation and at the end of the 6 hour period and preserved to establish microbial population abundances (bacteria, chroococcoid cyanobacteria, heterotrophic and phototrophic nanoplankton), the initial densities of the labeled prey and the abundance of mixotrophic nanoplankton. 
Experimental examination of algal phagotrophy

An experiment was designed to determine the influence of light, nutrients and prey density on phagotrophic behavior by algae in surface waters of the Sargasso Sea. Whole seawater samples were subdivided and treated, and microbial populations including mixotrophic nanoplankton were monitored for their responses to the addition of inorganic nutrients, labile organic carbon, and changes in light intensity. Water collection was conducted at approximately the location of the Bermuda Atlantic Time Series (BATS) station at $31^{\circ} \mathrm{N}, 64^{\circ} \mathrm{W}$. One experiment (Expt. I) was carried out between 27 and $31 \mathrm{March}$ 1992 with water collected from a depth of $10 \mathrm{~m}$. The experiment was repeated (Expt. II) between 5 and 9 April 1992 using water collected from a depth of $20 \mathrm{~m}$.

Water for the experiments was collected in several $0.1 \mathrm{~N} \mathrm{HCl}$-rinsed $5 \mathrm{~L}$ Niskin bottles using a rosette sampler. Water was pooled in acid-rinsed carboys and subsamples were removed and preserved with gluteraldehyde prior to filling incubation vessels in order to establish the initial microbial population abundances. Within 1 hour of collection duplicate clear $4 \mathrm{~L}$ polycarbonate vessels were filled with $3.5 \mathrm{~L}$ of sample and placed in an on-deck Plexiglas incubator with running seawater to maintain water at ambient surface water temperature. Light was adjusted with neutral density screening to approximately 50\% incident light. The experimental treatments (described below) were incubated over a 4 day period.

\footnotetext{
C Control, untreated seawater

G Seawater with daily additions of glucose $(10 \mu \mathrm{M} C)$

NP Seawater with daily additions of $\mathrm{NH}_{4}^{+}(5 \mu \mathrm{M})$ and $\mathrm{PO}_{4}^{-3}(0.5 \mu \mathrm{M})$

GNP Seawater with daily additions of glucose, $\mathrm{NH}_{4}^{+}$ and $\mathrm{PO}_{4}-3$ at above concentrations

LL Seawater at low light intensity ( $<5 \%$ incident light) without inorganic or organic additions

LLGNP Seawater at low light intensity with daily additions of glucose, $\mathrm{NH}_{4}{ }^{+}$and $\mathrm{PO}_{4}{ }^{3-}$ at above concentrations
} 
The purpose of adding glucose alone was to stimulate the bacterial assemblage and thereby cause an increase in their uptake of dissolved nutrients. This was expected to increased competition for nutrients with the phototroph assemblage. Lower concentrations of dissolved inorganic nutrients were hypothesized to favor mixotrophic algae that may be able to acquire nutrients by consumption of bacteria. Combining additions of glucose and inorganic $\mathrm{N}$ and $\mathrm{P}$ was expected to increase bacterial abundances without also causing a reduction in nutrient concentration, so that competition for nutrients would not be increased. This treatment would presumably favor mixotrophic algae that are able to take advantage of higher prey abundances. $\mathrm{N}$ and $\mathrm{P}$ were added alone to stimulate the growth of phototrophs. It was hypothesized that primarily heterotrophic species of mixotrophs and obligate photophagotrophs would continue to consume bacteria in these enclosures. Finally, the purpose of reducing light intensity was to decrease photosynthetic rates, while nutrients and glucose were added to stimulate the heterotroph assemblages in these enclosures. Mixotrophic algae that are able to supplement photosynthetic carbon by consuming bacterial $\mathrm{C}$ would presumably be favored in light limiting conditions, and primarily heterotrophic algae would be expected to do well in the presence of higher bacterial abundances resulting from added carbon and nutrients.

Subsamples $(750 \mathrm{ml})$ were removed from each experimental treatment vessel immediately after initiation of the experiment and incubated with FLB in $1.2 \mathrm{~L}$ polycarbonate vessels for 6 hours. These incubations were conducted using fluorescently labeled $P$. halodurans added at a concentration equal to $50 \%$ of the natural bacterial abundance. Following these incubations, preserved samples were examined by epifluorescence microscopy, as described earlier, to establish the abundances of mixotrophic nanoplankton and other microbial assemblages. This procedure was repeated on days 2 and 4 of the 4 day experimental incubation. 


\section{RESULTS}

\section{Abundances and vertical distributions of mixotrophic nanoplankton}

Labeled cyanobacteria were observed in the food vacuoles of chloroplastcontaining nanoplankton in surface water samples on all seven sampling dates in August 1989 (Table 2.1). Five of these surface water samples contained detectable but low abundances of algae with ingested labeled prey ( $<5 \%$ of phototrophic nanoplankton). However, on 15 and 16 August, we observed abundances of 144 mixotrophic nanoplankton ml-1 and 70 mixotrophic nanoplankton $\mathrm{ml}^{-1}$ representing $53 \%$ and $50 \%$ of the total phototrophic nanoplankton in the respective surface water samples (Table 2.1). These mixotrophic nanoplankton were $2-5 \mu \mathrm{m}$ in diameter. Considering only the phototrophic nanoplankton in this size range, $74 \%$ and $80 \%$ of the algae in the two surface water samples on 15 and 16 August contained ingested prey. These latter percentages are typical of percentages that might be observed for some species of bacterivorous heterotrophic nanoflagellate populations growing exponentially in laboratory cultures (Sieracki et al., 1987; Nygaard et al., 1988). This result indicates that an abundant and very active phagotrophic algal population was present in these two surface water samples. In contrast, ingested prey were not observed in any of the nanoplanktonic algae from samples collected in the deep chlorophyll maximum during August 1989.

Detailed vertical profiling conducted in early April 1992 indicated the presence of mixotrophic nanoplankton. The water column was weakly stratified during sampling in 1992 (Fig. 2.1), and there were pronounced peaks in chlorophyll concentration at 118 m on 1 April and at $132 \mathrm{~m}$ on 3 April. Coinciding with these deep chlorophyll maxima were peak abundances of photosynthetic nanoplankton (PNAN) of $1.2 \times 10^{3}$ PNAN ml-1 $^{-1}$ on 1 April (Fig. 2.2a) and 1.1 $\times 10^{3}$ PNAN ml-1 $^{-1}$ on 3 April (Fig. 2.3a). Changes in 
Table 2.1. Population abundances $( \pm 1$ SD) and percentages of phototrophic nanoplankton with ingested prey determined from water samples collected from seven sampling stations in the Sargasso Sea during August 1989. " + " indicates that phototrophic nanoplankton with ingested prey were present, but at an abundance $<5 \%$ of the total phototrophic nanoplankton abundance. "UN" indicates that phototrophic nanoplankton with ingested prey were undetected.

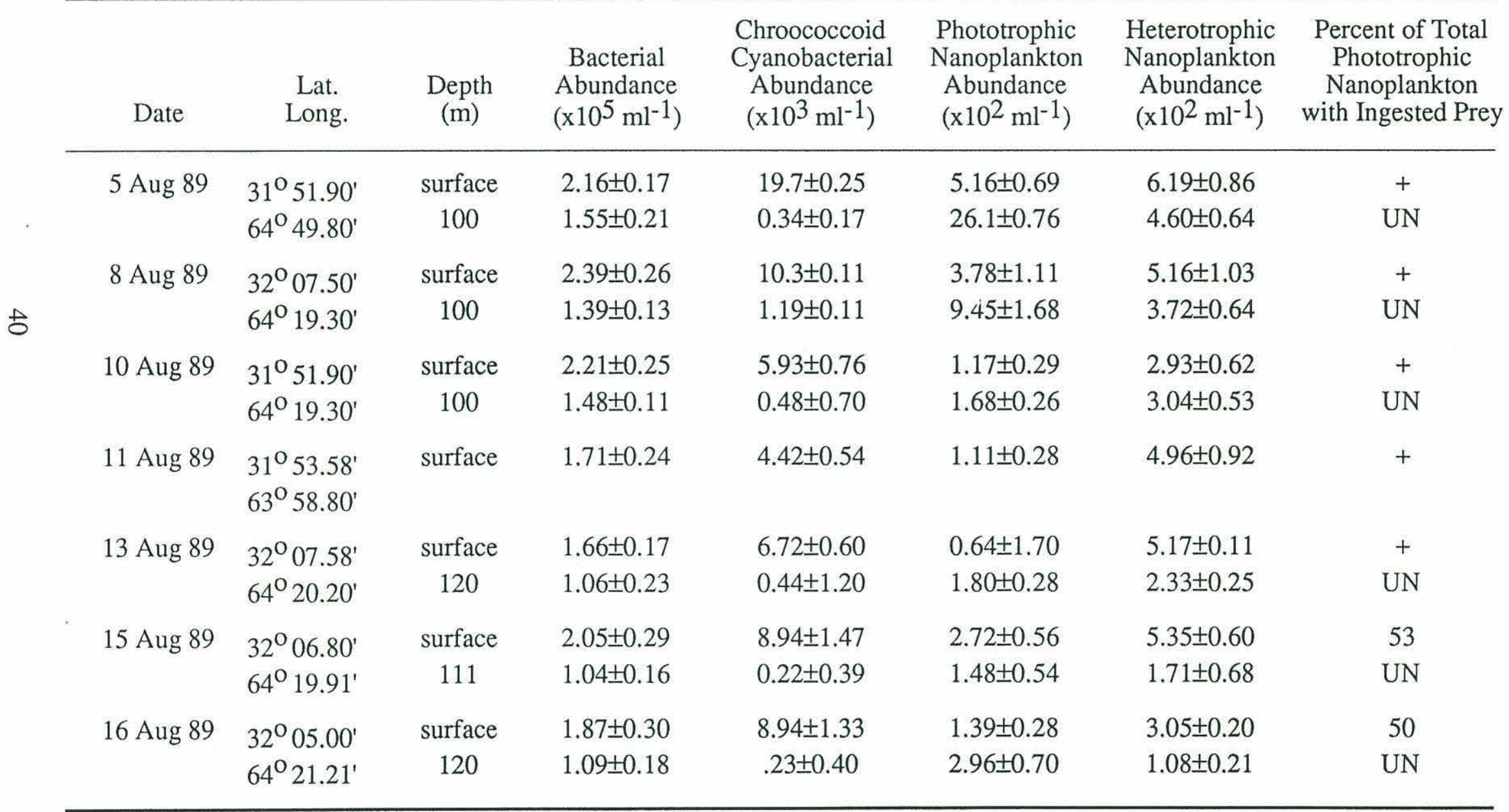




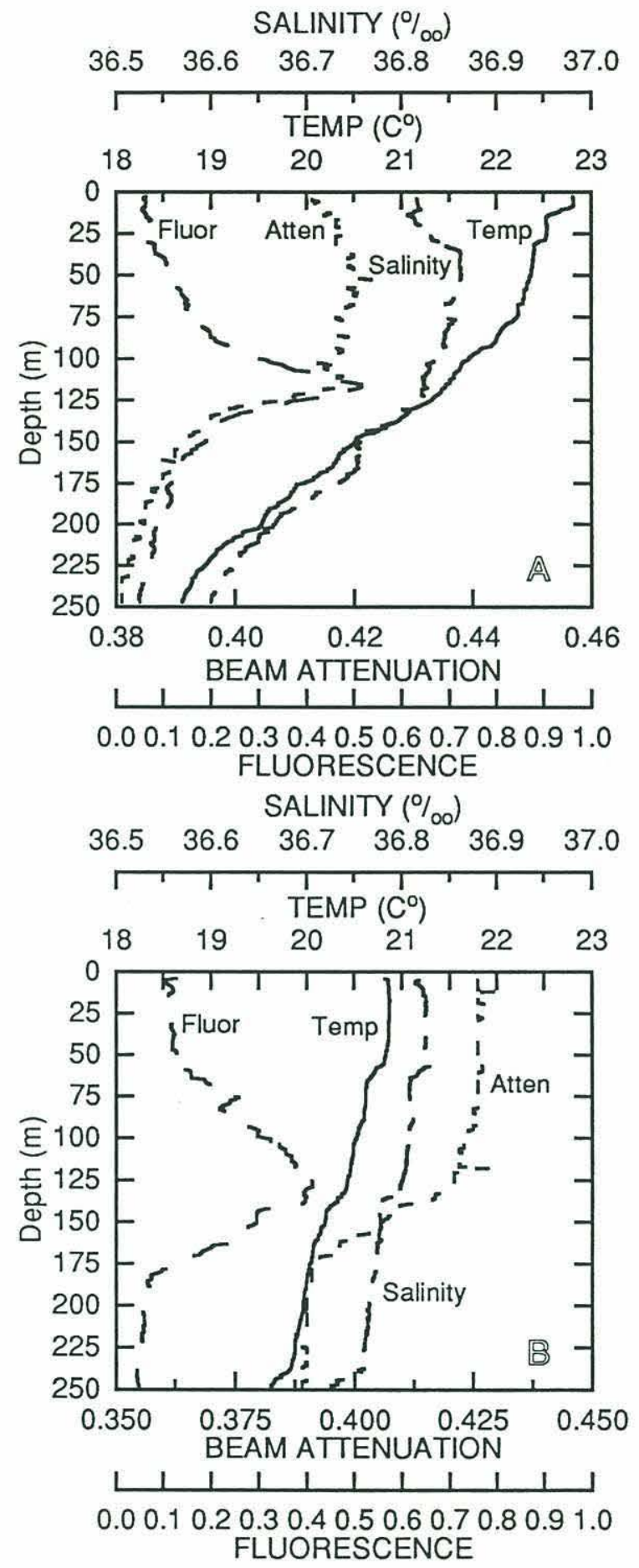

Figure 2.1. Vertical profiles of temperature, salinity, beam attenuation and fluorescence determined at $25^{\circ} 59^{\prime} \mathrm{N}, 64^{\circ} 30^{\prime} \mathrm{W}$ (A) sampled on 1 April 1992 and $30^{\circ} 26^{\prime} \mathrm{N}, 64^{\circ} 30^{\prime} \mathrm{W}$ (B) sampled on 3 April 1992. 

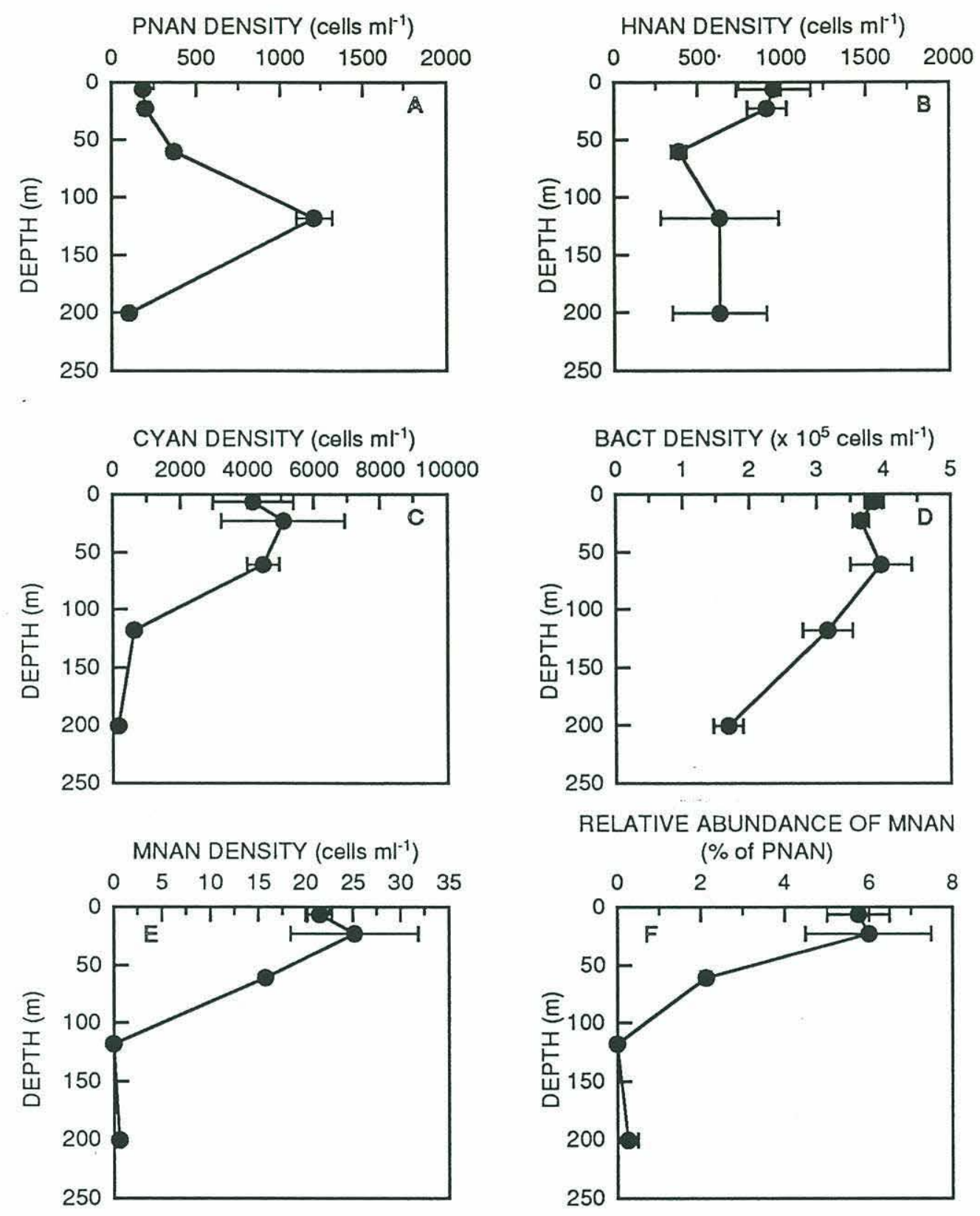

Figure 2.2. Vertical distribution of phototrophic nanoplankton (A), heterotrophic nanoplankton (B), chroococcoid cyanobacteria (C), bacteria (D) and mixotrophic nanoplankton absolute (E) and relative abundance (F) on 1 April 1992. 

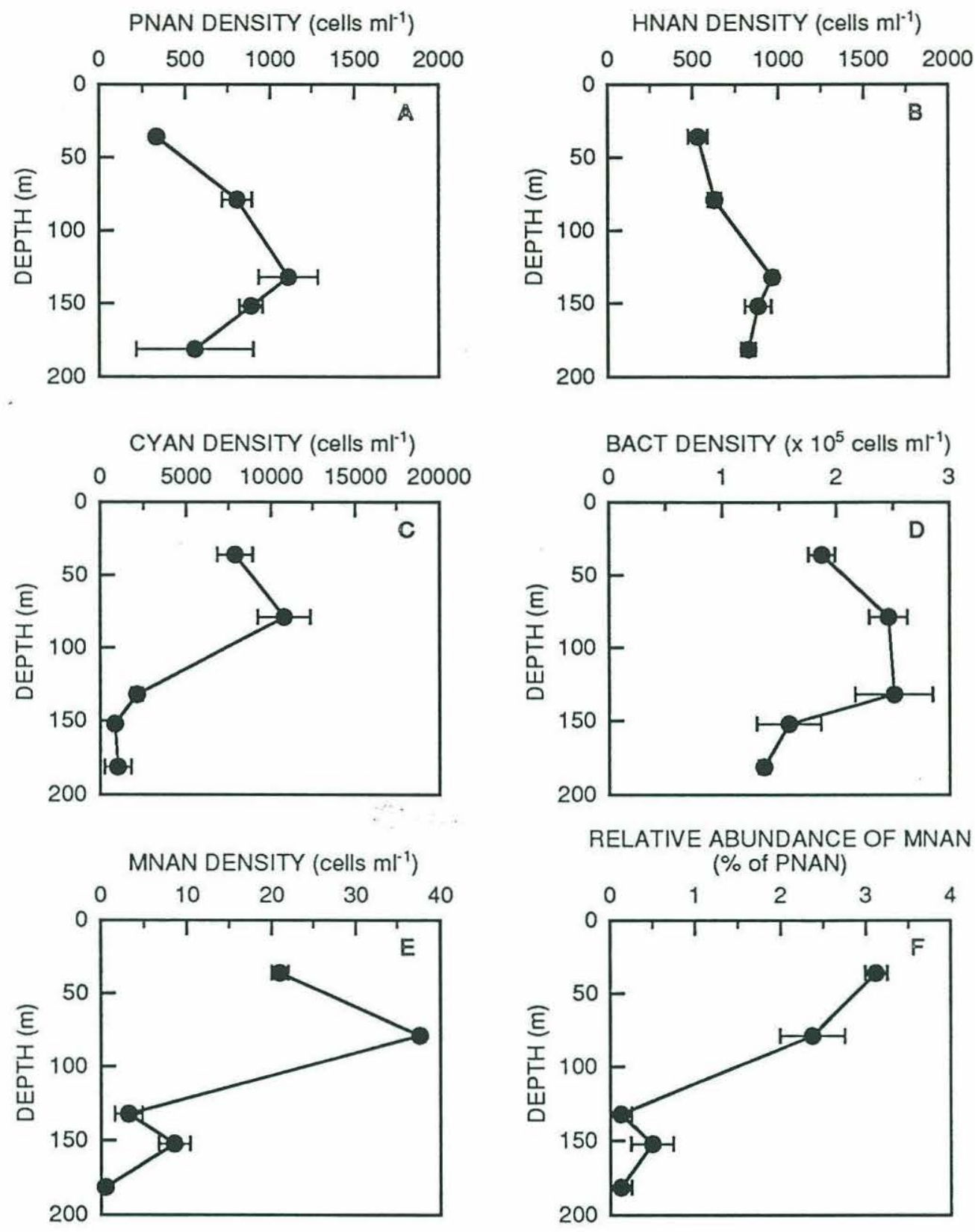

Figure 2.3. Vertical distribution of phototrophic nanoplankton (A), heterotrophic nanoplankton (B), chroococcoid cyanobacteria (C), bacteria (D) and mixotrophic nanoplankton absolute (E) and relative abundance (F) on 3 April 1992. 
bacterial abundances were less dramatic than changes in PNAN abundances. Bacterial abundances (BACT) peaked at $60 \mathrm{~m}$ on 1 April at $4.0 \times 10^{5} \mathrm{BACT} \mathrm{ml}^{-1}$ (Fig. 2.2d). On 3 April a maximum bacterial abundance of approximately $5 \times 10^{5} \mathrm{BACT} \mathrm{ml}^{-1}$ occurred at $132 \mathrm{~m}$ (Fig. 2.3d). Chroococcoid cyanobacteria (CYAN) abundances had subsurface maxima of $5.1 \times 10^{3} \mathrm{CYAN} \mathrm{ml}^{-1}$ and $1.1 \times 10^{4} \mathrm{CYAN} \mathrm{ml}^{-1}$ at $23 \mathrm{~m}$ on 1 April (Fig. 2.2c) and approximately $79 \mathrm{~m}$ on 3 April (Fig. 2.3c), respectively. The vertical distributions of heterotrophic nanoplankton (HNAN) were relatively uniform during this cruise. Their abundances ranged from $6 \times 10^{2}$ to $9 \times 10^{2} \mathrm{HNAN} \mathrm{ml}^{-1}$ on 1 April (Fig. 2.2b) and from $5.3 \times 10^{2}$ to $9.4 \times 10^{2} \mathrm{HNAN} \mathrm{ml}^{-1}$ on 3 April (Fig. $2.3 \mathrm{~b}$ ).

The relative abundance of mixotrophic nanoplankton was greatest in the shallower water samples at both stations, but overall, the density of MNAN represented a relatively small contribution to the total phototrophic nanoplankton assemblage at these depths ( $6 \%$, Fig. $2.2 \mathrm{f}$ and $<4 \%$, Fig. 2.3f). A maximum density of $25 \mathrm{MNAN} \mathrm{m}^{-1}$ was observed at $23 \mathrm{~m}$ on 1 April (Fig. 2.2e), and on 3 April, a maximum density of 38 MNAN ml-1 occurred at a depth of $79 \mathrm{~m}$ (Fig. 2.3e). On both sampling dates mixotrophic nanoplankton abundances in the DCM were at or below the limit of detection (<3 $\left.\mathrm{MNAN} \mathrm{ml}^{-1}\right)$.

Dissolved inorganic nutrients concentrations were low in surface waters during the study period. According to profiles of inorganic nutrient concentrations determined as a part of the BATS station sampling program on dates that bracketed the study period (18 March and 12 April 1992; Fig. 2.4), nitrogen was undetectable $(<0.05 \mu \mathrm{M})$ in surface waters down to a depth of $40 \mathrm{~m}$ while phosphorus concentrations were $« 0.1 \mu \mathrm{M}$ throughout the euphotic zone. Below $40 \mathrm{~m}$ to approximately $200 \mathrm{~m}$, dissolved inorganic nitrogen concentrations were between 0.4 and $1.0 \mu \mathrm{M}$. 

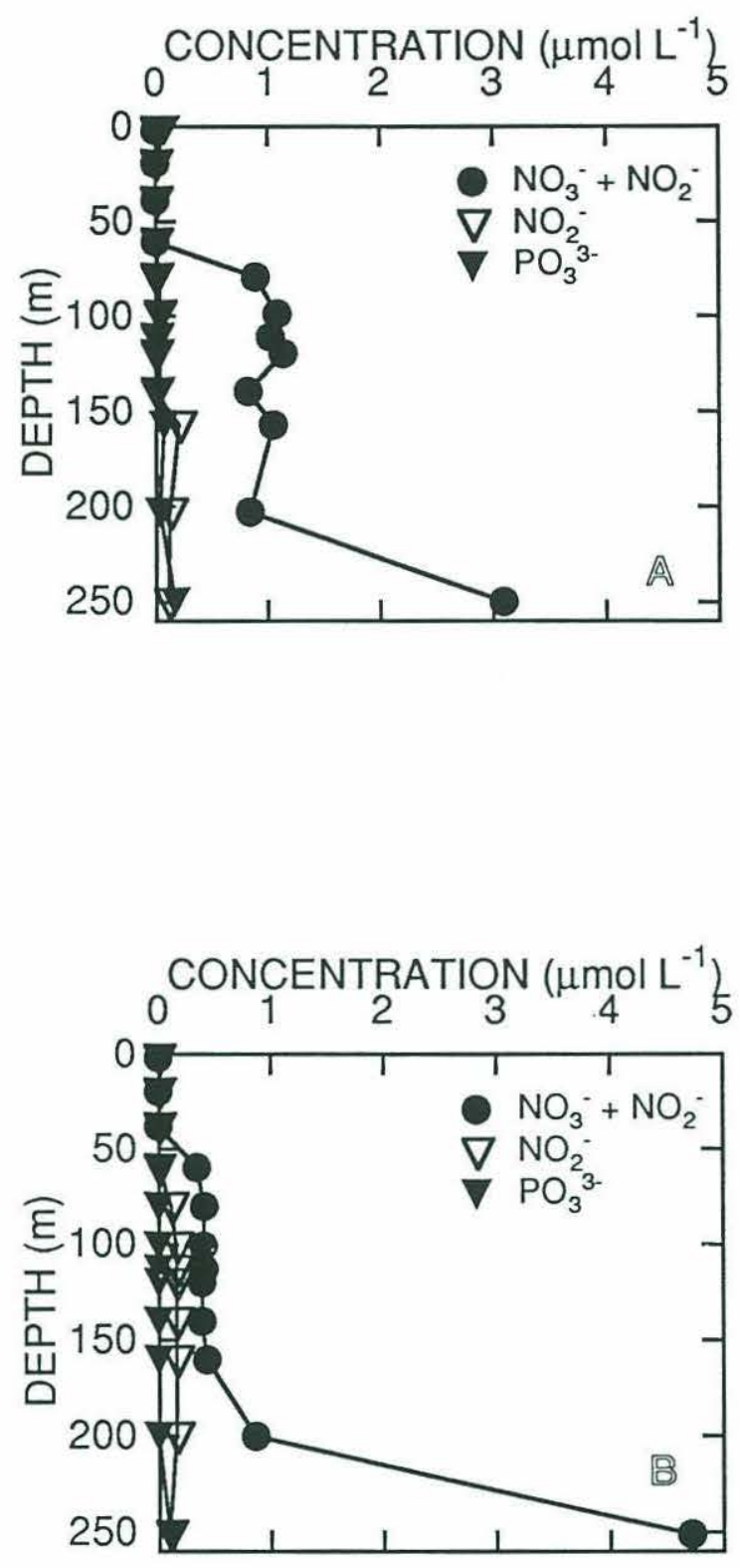

Figure 2.4. Vertical profiles of dissolved inorganic nitrogen and phosphorus concentrations at the Bermuda Atlantic Time Series station $\left(31^{\circ} \mathrm{N}, 64^{\circ} \mathrm{W}\right)$ on 18 March 1992 (A) and 12 April 1992 (B). Data kindly provided by BATS program. 
Microbial population responses to manipulations of light, nutrients, and prey density

Most microbial assemblages responded to the experimental manipulations during the 4 day period. Trends generally were apparent at day 2 but were not significantly different from day 0 values for some treatments. Analyses were therefore conducted using the results from day 4 , and treatments were contrasted to controls using transformed data to homogenize the variances. Significant differences were determined at the 0.05 significance level. The abundances of all microbial populations, except MNAN, did not change significantly in controls over the 4 day experimental period (Table 2.2). Absolute MNAN abundances decreased in controls during Expt. I and increased in controls during Expt. II. As a result, MNAN abundances in controls at the end of Expt. I were almost an order of magnitude lower than abundances in controls on day 4 of Expt. II even though day 0 abundances in both experiments were similar. Results from Expt. I, however, were similar to results from Expt. II with regard to the change in MNAN abundance in each treatment as compared to the control (Figs. 2.5e; 2.6e).

Bacterial abundances were significantly greater than controls on day 4 in the GNP and LLGNP treatments in both Expt. I and Expt. II (Fig. 2.5a; 2.6a). In these two treatments bacterial abundances reached values of $2 \times 10^{6}$ and $3 \times 10^{6}$ BACT ml-1, respectively. Abundances in controls were $\leq 5 \times 10^{5} \mathrm{BACT} \mathrm{ml}-1$. Heterotrophic nanoplankton abundances in Expt. I did not increase significantly in the GNP or LLGNP treatments. HNAN abundances in the NP and GNP treatments, however, did appear to be slightly elevated in comparison to controls, although not significantly. These small increases may have been due to HNAN preying primarily upon members of the phototroph assemblages which increased significantly in these two treatments during Expt. I (see below). HNAN abundances in Expt. II were significantly greater than controls on day 4 in the GNP and LLGNP treatments (Fig. 2.6c). Presumably, this 
Table 2.2. Population abundances ( \pm 1 SD) in controls determined at the beginning and end of each 4 day experimental incubation. Experiment I was conducted from March 27-31 and Experiment II was conducted from April 5-9, 1992.

\begin{tabular}{lccccc}
\hline Experiment & $\begin{array}{c}\text { Chroococcoid } \\
\text { Abundance } \\
\left(\mathrm{x} 10^{5} \mathrm{ml}^{-1}\right)\end{array}$ & $\begin{array}{c}\text { Phototrophic } \\
\text { Cyanobacterial } \\
\text { Abundance } \\
\left(\mathrm{x} 10^{3} \mathrm{ml}^{-1}\right)\end{array}$ & $\begin{array}{c}\text { Nanoplankton } \\
\text { Abundance } \\
\left(\mathrm{x} 10^{2} \mathrm{ml}^{-1}\right)\end{array}$ & $\begin{array}{c}\text { Heterotrophic } \\
\text { Nanoplankton } \\
\text { Abundance } \\
\left(\mathrm{x} 10^{3} \mathrm{ml}^{-1}\right)\end{array}$ & $\begin{array}{c}\text { Mixotrophic } \\
\text { Nanoplankton } \\
\text { Abundance } \\
\left(\mathrm{ml}^{-1}\right)\end{array}$ \\
\hline
\end{tabular}

I

$\begin{array}{cccccc}\text { Day 0 } & 5.02 \pm 0.23 & 7.56 \pm 1.28 & 8.16 \pm 2.17 & 1.42 \pm 0.34 & 18.84 \pm 5.50 * \\ \text { Day 4 } & 3.46 \pm 0.11 & 6.26 \pm 2.06 & 6.22 \pm 2.45 & 1.51 \pm 0.52 & 7.77 \pm 3.06 * \\ \text { II } & & & & & \\ \text { Day 0 } & 4.48 \pm 0.72 & 17.9 \pm 6.11 & 11.5 \pm 3.17 & 8.13 \pm 0.03 & 17.45 \pm 5.98 * \dagger \\ \text { Day 4 } & 4.31 \pm 6.10 & 7.49 \pm 10.6 & 12.5 \pm 17.6 & 8.00 \pm 1.13 & 78.62 \pm 56.90 *\end{array}$

* Indicates Day 0 and Day 4 population abundances are significantly different (P-value $=0.05)$. Significant differences were determined by contrasts performed on transformed (ln or $-1 / x)$ data.

$\dagger$ FLB concentration used for this initial incubation was $\approx 100 \%$ of natural bacterial abundance. 

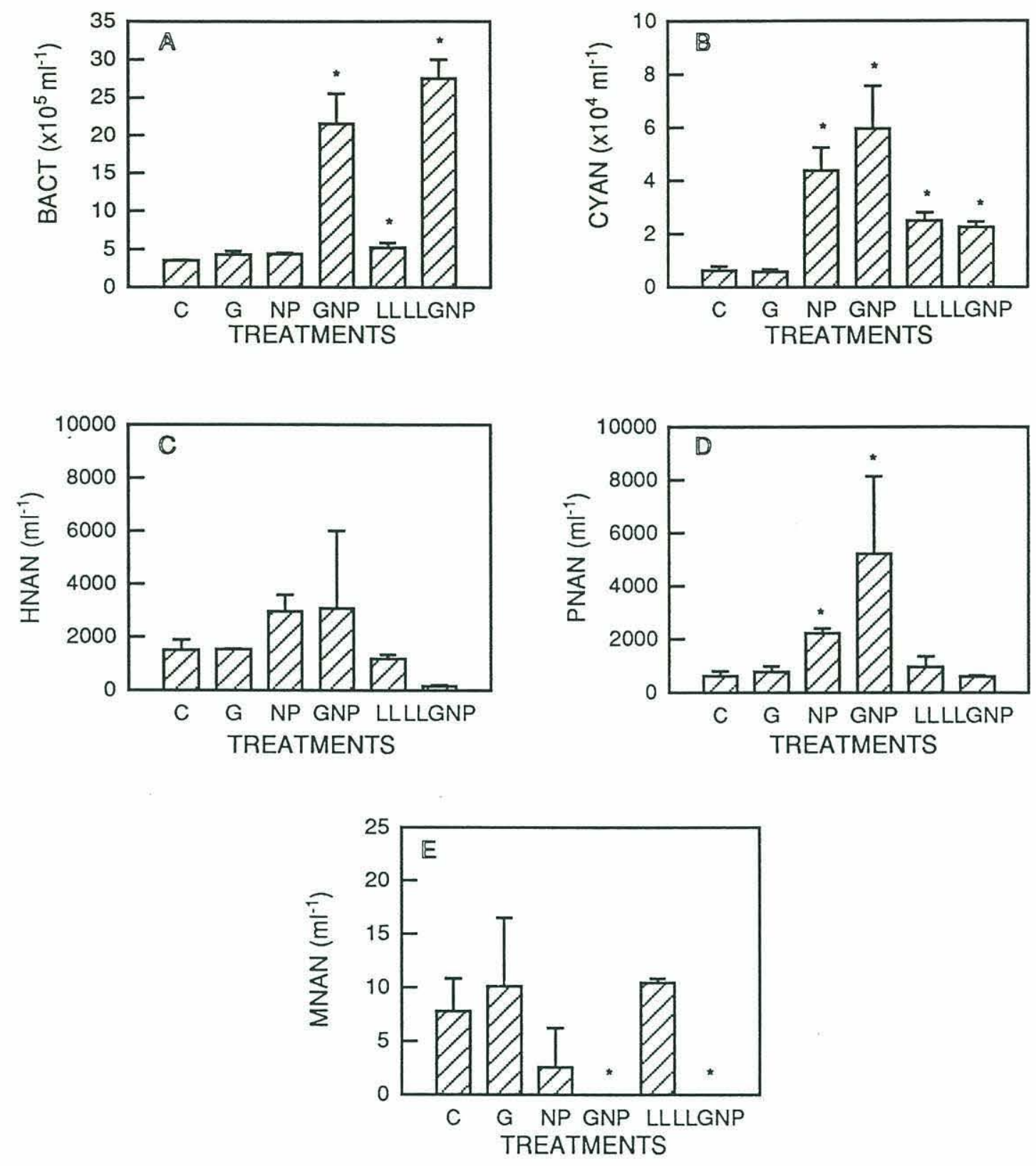

Figure 2.5. Mean population abundances $( \pm 1 \mathrm{SD})$ of bacteria (A), chroococcoid cyanobacteria (B), phototrophic nanoplankton (C), heterotrophic nanoplankton (D), and mixotrophic nanoplankton $(\mathrm{E})$ in controls $(\mathrm{C})$, glucose $(\mathrm{G})$, nitrogen+phosphorus (NP), glucose+nitrogen+phosphorus (GNP), low light (LL) and low light with glucose+ nitrogen+phosphorus (LLGNP) treatments at the end of a 4 day experimental incubation conducted from 27-31 March 1992 with water collected from a depth of $10 \mathrm{~m}$ at $25^{\circ} 59^{\prime} \mathrm{N}, 64^{\circ} 30^{\prime} \mathrm{W}$ in the Sargasso Sea. Significant differences between treatments and controls are indicated by "*" (P-value $=0.05)$. See text for details of treatments. 

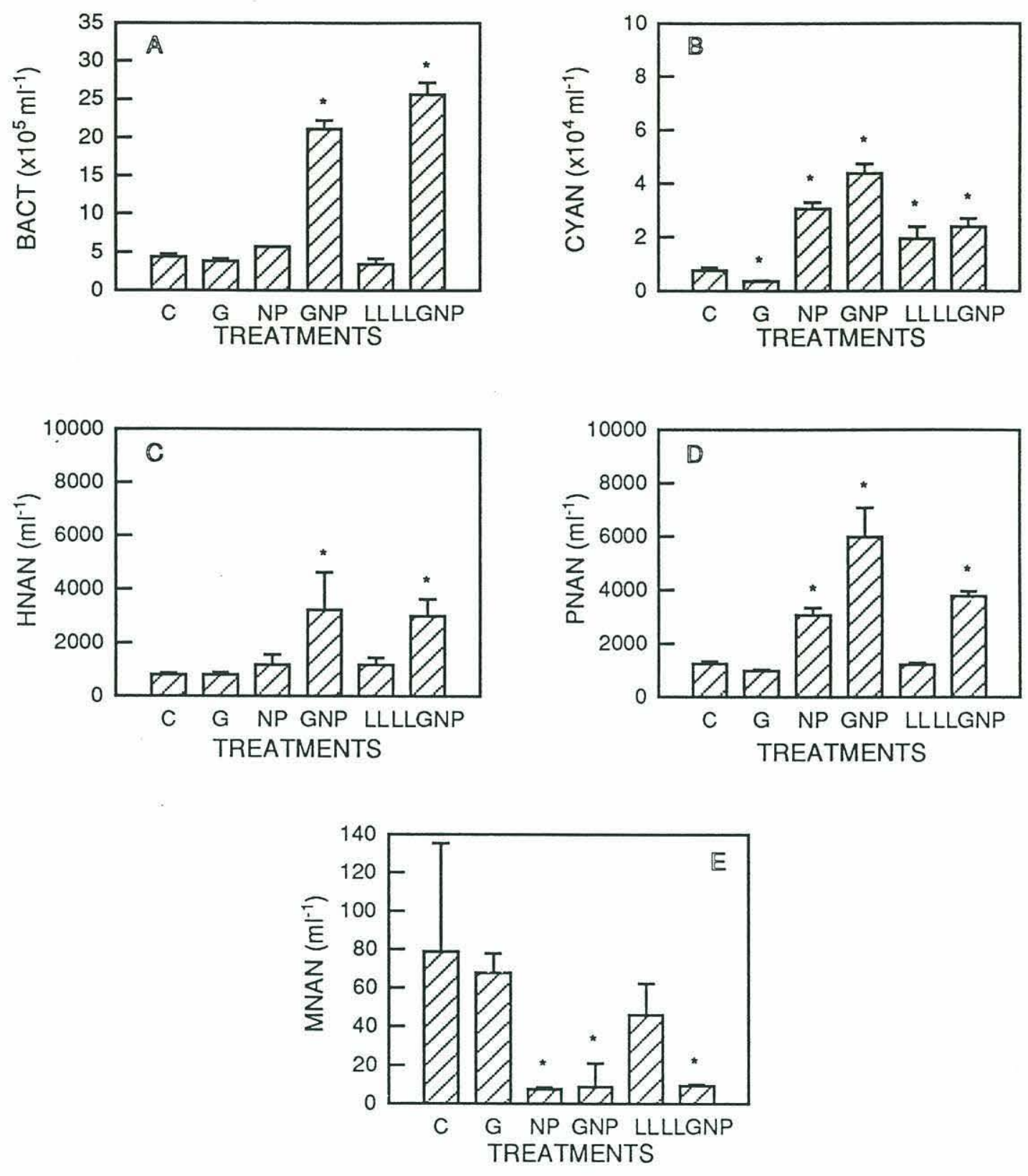

Figure 2.6. Mean population abundances ( $\pm 1 \mathrm{SD}$ ) of bacteria (A), chroococcoid cyanobacteria (B), phototrophic nanoplankton (C), heterotrophic nanoplankton (D) and mixotrophic nanoplankton (E) in controls $(C)$, glucose $(G)$, nitrogen+phosphorus (NP), glucose+nitrogen+phosphorus (GNP), low light (LL) and low light with glucose+ nitrogen+phosphorus (LLGNP) treatments at the end of a 4 day experimental incubation conducted from 5-9 April 1992 with water collected from a depth of $20 \mathrm{~m}$ at $30^{\circ} 26^{\prime} \mathrm{N}, 64^{\circ} 30^{\prime} \mathrm{W}$ in the Sargasso Sea. Significant differences between treatments and controls are indicated by "*" (P-value $=0.05)$. See text for details of treatments. 
response was due to the increase in bacterial prey abundance that also occurred in these treatments.

Abundances of cyanobacteria (CYAN) and non-phagocytizing phototrophic nanoplankton (PNAN) responded to nutrient supplementation and changes in light intensity (Fig. 2.5b, d; 2.6b, d). CYAN and PNAN abundances in treatments that received additions of inorganic nitrogen and phosphorus (NP, GNP) were significantly higher than abundances in controls. PNAN abundances were also significantly higher than abundances in controls in the LLGNP treatment on day 4 of Expt. II. Abundances of CYAN were significantly higher than abundances in controls in both low light treatments (LL, LLGNP) at the end of both experiments. CYAN abundances on day 4 ranged from $\leq 1 \times 10^{4} \mathrm{CYAN} \mathrm{ml}^{-1}$ in controls to $\sim 5 \times 10^{4} \mathrm{CYAN} \mathrm{ml}^{-1}$ and $\geq 6 \times 10^{4} \mathrm{CYAN}$ $\mathrm{ml}^{-1}$ in the GNP treatments in Expt. I and Expt. II, respectively. Abundances of PNAN ranged from $\sim 1 \times 10^{3}$ PNAN ml-1 $^{-1}$ in controls to $\sim 6 \times 10^{3}$ PNAN ml-1 $^{-1}$ in the GNP treatments at the end of Expt. I and Expt. II. These increases in the abundances of CYAN and PNAN correspond to net growth rates of approximately $0.4 \mathrm{~d}^{-1}$ for these assemblages. PNAN and CYAN abundances in the glucose amended treatment $(\mathrm{G})$ on day 4 were not significantly increased relative controls (Expt. I $\sim 1 \times 10^{3}$ PNAN ml $^{-1}$, Expt. II $\leq 1 \times 10^{4} \mathrm{CYAN} \mathrm{ml}^{-1}$ ).

Mean MNAN abundances in controls on day 4 were $\sim 8 \mathrm{ml}^{-1}$ in Expt. I and $\sim 80$ $\mathrm{ml}^{-1}$ in Expt. II, and MNAN abundances in the glucose (G) and low light (LL) treatments were not significantly different from controls (Fig. 2.5e; 2.6e). Mean abundances of MNAN in the treatments that received additions of inorganic nutrients in Expt. II (NP=7.6 ml-1, GNP=8.7 ml-1, LLGNP=9.3 ml-1), on the other hand, were significantly lower than MNAN abundances in controls at the end of Expt. II. While the same pattern was also apparent among treatments at the end of Expt. I, only the GNP and LLGNP treatments were significantly different from controls. The variances associated 
with this first experiment, however, were high due to the very low abundances of MNAN observed during this experiment. 


\section{DISCUSSION}

\section{Algal phagotrophy in surface waters of the Sargasso Sea}

The results of the 4 day experimental incubations support the supposition that nutrients limited algal growth in surface waters at the time of the study. Cyanobacteria and phototrophic nanoplankton abundances increased substantially (by a factor of 5-6) in treatments that were enriched with inorganic nutrients (NP, GNP, LLGNP). Their abundances did not change in the controls (C) or the glucose amended treatment $(\mathrm{G})$. PNAN also did not increase in the low light treatment (LL). The heterotrophic bacterial population experienced no significant increases in abundance with the addition of inorganic nutrients (NP) or glucose (G) added separately, but they experienced a large increase when inorganic nutrient enrichment was accompanied by additions of labile organic carbon (GNP, LLGNP). These results indicate that bacterial growth was colimited (or close to co-limitation) by inorganic nutrients and organic carbon supply.

In contrast to the phototrophs, mixotrophic nanoplankton were less abundant in nutrient enriched treatments (NP, GNP, LLGNP) at the end of the 4 day experimental incubations and more abundant in treatments that were nutrient limited (C, G, LL). Based on these results, we suggest that phagotrophy may provide mixotrophic algae in surface waters of the Sargasso Sea with major nutrients. During periods of low nutrient concentrations phagotrophic behavior may enable mixotrophic algae to survive in competition with purely phototrophic algae. When dissolved nutrient concentrations are increased, though, mixotrophic algae may be out-competed by other phototrophs. This scenario could account for the low abundances of mixotrophs in nutrient enriched treatments.

On the other hand, while mixotrophic algae present in surface waters of the Sargasso Sea may satisfy nutrient requirements via phagotrophy during periods of 
nutrient limitation, they may be capable of abandoning this behavior in favor of phototrophic acquisition of dissolved nutrients when dissolved nutrient concentrations are increased. Mixotrophs not actively engaged in phagotrophy would not be detectable by the FLB uptake method that we employed. Decreases in mixotroph abundances with nutrient enrichment could therefore have been due to a cessation in phagotrophic activity by mixotrophic algae rather than actual decreases in their abundances. Support for this alternative explanation is found in a study by Nygaard and Tobiesen (1993) who examined bacterivory by several species of marine mixotrophic flagellates in P-limited and non-limited conditions. They observed that bacterial ingestion rates by some species were higher under conditions of P-limited phototrophic growth. Similarly, a field study conducted in a chrysophyte-dominated freshwater lake containing large numbers of phagotrophically active Dinobryon spp., indicated that the percent of Dinobryon cells with ingested prey decreased when dissolved nutrients were added, but the actual number of Dinobryon cells increased provided there was adequate light for photosynthesis (Chapter 4). Nutrient limitation, whether it influences cell numbers or phagotrophic activity, may explain the observations of higher mixotroph abundances in surface waters during this study.

Mixotrophic species in which phagotrophy serves different purposes may have been present in water samples at the time of this study, but our data do not support this contention. For example, it is possible that mixotrophic algae deficient in their ability to synthesize a required growth compound, similar to Uroglena americana (Kimura \& Ishida, 1989), were present in surface waters. Rather than acquiring major nutrients, phagotrophic behavior may be necessary for these algae to obtain an essential growth factor. Mixotrophs with this growth strategy, however, would be expected to respond favorably to increased prey abundance. Yet, increases in mixotroph abundances were not observed in treatments that had increased bacterial abundances (GNP, LLGNP). 
Based on this information we conclude that mixotrophic species displaying this trophic behavior were probably not important in surface waters at the time of this study.

Mixotrophic species that are primarily heterotrophic and satisfy most of their carbon and nutrient requirements by phagotrophy were also probably not important contributors to the mixotroph assemblage in surface waters at the time of this study. Mixotrophs with this growth strategy would have been expected to increase in abundance in both low light treatments (due to a competitive advantage under poor phototrophic conditions, and/or the treatment with added carbon and nutrients (due to increased prey abundance). Perhaps low bacterial abundances in the low light treatment without any additions prevented an increase in their abundance in this treatment, but this should not have been the case in the low light treatment with added glucose, $\mathrm{N}$ and $\mathrm{P}$, or in the ambient light treatment with added glucose, $\mathrm{N}$ and $\mathrm{P}$. Abundances of mixotrophic nanoplankton in these treatments were not significantly different from abundances in controls even though bacterial abundances in these treatments were above $1 \times 10^{6} \mathrm{ml}^{-1}$, the reported grazing threshold for species with similar growth strategies (Sanders et al., 1990).

A potential source of bias that may possibly account for the decrease in MNAN abundances in the two treatments enriched with C, N and P (GNP \& LLGNP), though, is the ratio of fluorescently labeled prey to natural bacteria used in the FLB uptake experiments to examine ingestion by phototrophic nanoplankton. Increased numbers of bacterial prey in the GNP and LLGNP treatments would have been expected to increase the competitive capabilities of mixotrophic species that are primarily heterotrophic. However, because all of the 6 hour FLB incubations were conducted with the same absolute abundance of FLB added, the FLB:bacteria ratio on day 4 was 5 times lower in the GNP and LLGNP treatments than in the other treatments. Some actively feeding mixotrophs may not have contained any ingested FLB as a result, and the actual number 
of MNAN may have been underestimated in these two treatments. We investigated this potential bias using ingestion and digestion rates taken from the literature, as follows.

The ratio of FLB to natural bacteria in the treatments receiving additions of glucose, nitrogen and phosphorus (GNP and LLGNP) was approximately 1:10. In the other treatments $(\mathrm{C}, \mathrm{G}, \mathrm{NP}, \mathrm{LL})$, it was approximately $1: 2$. Average ingestion rates for mixotrophic nanoplankton range from 5-103 bacteria cell-1 $\mathrm{h}^{-1}$ (Bird \& Kalff, 1987; Caron et al., 1990; Caron et al., 1992). Digestion times for phagotrophic protozoa are reported to be between 30-60 minutes (Sherr et al., 1988; Jones et al., 1993). Assuming a conservative ingestion rate of 20 bacteria cell $^{-1} \mathrm{~h}^{-1}$ and a digestion time of 30 minutes, we calculated that there should have been at least 1 ingested FLB per actively feeding mixotroph in the GNP and LLGNP treatments at any given time and at least 5 FLB per actively feeding mixotroph in the other treatments (C, G, NP, LL). It is therefore unlikely that the ratio of FLB to natural bacteria lead to an underestimation of mixotroph abundance in the GNP and LLGNP treatments in either experiment.

MNAN abundances may, however, have been underestimated to some degree in nutrient enriched treatments due to a reduction in the ability to detect MNAN as a result of increased PNAN abundances in these treatments. The limit of detection for MNAN can be calculated from the number of PNAN examined for ingested FLB (400) and total PNAN abundance. The limit of detection for the treatments in which abundances of PNAN were not significantly different from controls was $\leq 3 \mathrm{MNAN} \mathrm{ml}^{-1}$. On the other hand, the limits of detection for treatments with significantly increased abundances of PNAN ranged from approximately $5 \mathrm{MNAN} \mathrm{ml}^{-1}$ in the NP treatment in Expt. I to 15 MNAN ml-1 in the GNP treatment in Expt. II. Thus, actual abundances of MNAN may have been as high as $5 \mathrm{ml}^{-1}$ in the NP treatment and $12 \mathrm{ml}^{-1}$ in the GNP treatment in Expt. I, and as high as $7 \mathrm{ml}^{-1}$ in the NP treatment, $15 \mathrm{ml}^{-1}$ in the GNP treatment and 10 $\mathrm{ml}^{-1}$ in the LLGNP treatment in Expt. II and still have gone undetected. Because abundances of MNAN in controls at the end of Expt. I were $<10 \mathrm{ml}^{-1}$, MNAN 
abundances in the NP and GNP treatments in this experiment may not have been significantly different from MNAN abundances in controls. On the other hand, overall abundances of MNAN at the end of Expt. II were almost an order of magnitude greater than MNAN abundances at the end of Expt. I (nearly $80 \mathrm{ml}^{-1}$ in controls). Therefore, even if MNAN abundances in the NP, GNP and LLGNP treatments in Expt. II were as high as the calculated limits of detection, they would still have been significantly lower than MNAN abundances in controls.

Vertical distribution of mixotrophic nanoplankton in euphotic zone waters of the Sargasso Sea

Based on the experimental results, it can be hypothesized that the mixotroph assemblage in surface waters of the Sargasso Sea during this study was dominated by mixotrophic nanoplankton that satisfy some or all of their nutrient requirements via phagotrophy, and nutrient availability may therefore account for the vertical distribution of mixotrophic nanoplankton. High abundances of mixotrophic nanoplankton were observed in surface waters, but near the base of the euphotic zone, mixotrophic nanoplankton were nearly undetectable. Phagotrophic behavior by algae in oligotrophic surface waters may be competitively advantageous, even if phagotrophic acquisition of nutrients is energetically expensive relative to the uptake of dissolved nutrients. This strategy for nutrient acquisition may not be competitive in high nutrient environments, though, and may account for low abundances of mixotrophs near the base of the euphotic zone where nutrient concentrations were high. Alternatively, mixotrophs may have been just as abundant near the base of the euphotic zone as in surface waters, but they may have reduced or ceased phagotrophic activity in response to high concentrations of dissolved nutrients. 
Another possible explanation that may also account for lower abundances of mixotrophs near the base of the euphotic zone is that mixotrophic algae may be light limited at these deeper depths. Some species of mixotrophic algae are incapable of continued growth at low light intensity (Caron et al., 1992). Perhaps mixotrophic algae present in euphotic zone waters of the Sargasso Sea require high light for growth. If so, mixotrophic algae may have been simply out-competed near the base of the euphotic zone by other phototrophs better adapted for growth at low light intensity.

While reasons for the observations of low abundances of MNAN near the base of the euphotic zone remain unclear, evidence has been provided in this paper to suggest that phagotrophic behavior by mixotrophic algae in surface waters of the Sargasso Sea was a consequence of the generally low nutrient concentrations at these depths. On two occasions, high abundances of mixotrophs were observed in surfaces waters. It is hypothesized that phagotrophy may permit mixotrophic algae to survive in competition with other phototrophs by providing them with a supplemental source of nutrients. This behavior may, on occasion, allow mixotrophic algae to become important contributors to the nanoplankton assemblage in oligotrophic surface waters of the Sargasso Sea. 


\section{REFERENCES}

Andersson, A., Falk, S., Samuelsson, G. \& Hagström, ̊̊. 1989 Nutritional characteristics of a mixotrophic nanoflagellate, Ochromonas sp. Microbial Ecology 17, $117-128$

Berninger, U.-G., Caron, D. A. \& Sanders, R. W. 1992 Mixotrophic algae in three icecovered lakes of the Pocono Mountains, U.S.A. Freshwater Biology 28, 263-272

Bird, D. F. \& Kalff, J. 1987 Algal phagotrophy: Regulating factors and importance relative to photosynthesis in Dinobryon (Chrysophyceae). Limnology and Oceanography 32, 277-284

Bird, D. F. \& Kalff, J. 1989 Phagotrophic sustenance of a metalimnetic phytoplankton peak. Limnology and Oceanography 34, 155-162

Bockstahler, K. R. \& Coats, D. W. 1993 Spatial and temporal aspects of mixotrophy in Chesapeake Bay dinoflagellates. Journal of Eukaryotic Microbiology 40, 49-60

Børsheim, K. Y., Harboe, T., Johansen, T., Nordland, S. \& Nygaard, K. 1989 Flow cytometric characterisation and enumeration of Chrysochromulina polylepis during a bloom along the Norwegian coast. Marine Ecology Progress Series 54, 307-309

Caron, D. A. 1983 Technique for enumeration of heterotrophic and phototrophic nanoplankton, using epifluorescence microscopy, and comparison with other procedures. Applied and Environmental Microbiology 46, 491-498

Caron, D. A., Porter, K. G. \& Sanders, R. W. 1990 Carbon, nitrogen and phosphorus budgets for the mixotrophic phytoflagellate Poterioochromonas malhamensis

(Chrysophyceae) during bacterial ingestion. Limnology and Oceanography 35, 433-443

Caron, D. A., Sanders, R. W., Lim, E. L., Marrasé, C., Amaral, L. A., Whitney, S., Aoki, R. B. \& Porter, K. G. 1992 Light-dependent phagotrophy in the freshwater mixotrophic chrysophyte Dinobryon cylindricum. Microbial Ecology 25, 93-111

Dahl, D., Lindahl, O., Paasche, E. \& Throndsen, J. 1989 The Chrysochromulina polylepis bloom in Scandinavian waters during Spring, 1988. In Novel Phytoplankton Blooms: causes and impacts of recurrent brown tides and other unusual blooms (Cosper, E. M., Bricelj, V. M. \& Carpenter, E. J., eds.). Springer-Verlag, Berlin. pp. 383-405.

Estep, K. W., Davis, P. G., Keller, M. D. \& Sieburth, J. M. 1986 How important are oceanic algal nanoflagellates in bacterivory. Limnology and Oceanography 31, 646-650

Fenchel, T. 1982a Ecology of heterotrophic microflagellates. II. Bioenergetics and growth. Marine Ecology Progress Series 8, 225-231

Fenchel, T. 1982b Ecology of heterotrophic microflagellates. IV. Quantitative occurrence and importance as bacterial consumers. Marine Ecology Progress Series 9, $35-42$

Johnsen, T. M. \& Lein, T. E. 1989 Prymnesium parvum Carter, (Prymnesiophyceae) in association with macroalgae in Ryfylke, southwestern Norway. Sarsia 74, 277-281 
Jones, H. L. J., Leadbeater, B. S. C. \& Green, J. C. 1993 Mixotrophy in marine species of Chrysochromulina (Prymnesiophyceae): Ingestion and digestion of a small green flagellate. Journal of the Marine Biological Association of the United Kingdom 73, 283-296

Kimura, B. \& Ishida, Y. 1986 Possible phagotrophic feeding of bacteria in a freshwater red tide Chrysophyceae Uroglena americana. Bulletin of the Japanese Society of Scientific Fisheries 52, 697-701

Kimura, B. \& Ishida, Y. 1989 Phospholipid as a growth factor of Uroglena americana, a red tide Chrysophyceae in Lake Biwa. Nippon Suisan Gakkaishi 55, 799-804

Lewitus, A. J. \& Caron, D. A. 1991 Physiological responses of phytoflagellates to dissolved organic substrate additions. I. Dominant role of heterotrophic nutrition in Poterioochromonas malhamensis (Chrysophyceae). Plant and Cell Physiology 32, 671680

Morris, I. 1980 Physiological ecology of phytoplankton. vol. 7. University of California Press, Berkeley.

Nygaard, K., Børsheim, K. Y. \& Thingstad, T. F. 1988 Grazing rates on bacteria by marine heterotrophic microflagellates compared to uptake rates of bacterial-sized monodispersed fluorescent latex beads. Marine Ecology Progress Series 44, 159-165

Nygaard, K. \& Hessen, D. O. 1990 Use of ${ }^{14}$ C-protein-labeled bacteria for estimating clearance rates by heterotrophic and mixotrophic flagellates. Marine Ecology Progress Series $68,7-14$

Nygaard, K. \& Tobiesen, A. 1993 Bacterivory in algae: A survival strategy during nutrient limitation. Limnology and Oceanography 38, 273-279

Pace, M. L., McManus, G. B. \& Findlay, S. E. G. 1990 Planktonic community structure determines the fate of bacterial production in a temperate lake. Limnology and Oceanography 35, 795-808

Pascher, A. 1911 Cyrtophora, eine neue tentakeltragende Chrysomonade aus franzensbad und ihre verwandten. Ber. Deutsch. Bot. Ges. 29,112-125

Porter, K. G. \& Feig, Y. S. 1980 The use of DAPI for identifying and counting aquatic microflora. Limnology and Oceanography 25, 943-948

Pringsheim, E. G. 1952 On the nutrition of Ochromonas. Quarterly Journal of Microscopical Science 93, 71-96

Pringsheim, E. G. 1955 Uber Ochromonas danica n. sp. und andere Arten der Gattung. Archiv für Mikrobiologie 23, 181-192

Sanders, R. W. 1991 Mixotrophic protists in marine and freshwater ecosystems. Journal of Protozoology 38, 76-81

Sanders, R. W. \& Porter, K. G. 1988 Phagotrophic phytoflagellates. Advances in Microbial Ecology 10, 167-192 
Sanders, R. W., Porter, K. G. \& Caron, D. A. 1990 Relationship between phototrophy and phagotrophy in the mixotrophic chrysophyte Poterioochromonas malhamensis. Microbial Ecology 19, 97-109

Schnepf, E. \& Elbrächter, M. 1992 Nutritional strategies in dinoflagellates: A review with emphasis on cell biological aspects. European Journal of Protistology 28, 3-24

Sherr, B. F., Sherr, E. B. \& Fallon, R. D. 1987 Use of monodispersed, fluorescently labeled bacteria to estimate in situ protozoan bacterivory. Applied and Environmental Microbiology 53, 958-965

Sherr, B. F., Sherr, E. B. \& Rassoulzadegan, F. 1988 Rates of digestion of bacteria by marine phagotrophic protozoa: temperature dependence. Applied and Environmental Microbiology 54, 1091-1095

Sherr, E. B., Caron, D. A. \& Sherr, B. F. 1993 Staining of heterotrophic protists for visualization via epifluorescence microscopy. In Current Methods in Aquatic Microbial Ecology (Kemp, P., Cole, J., Sherr, B. \& Sherr, E., eds.). Lewis Publishers, pp. 213228.

Sieracki, M. E., Haas, L. W., Caron, D. A. \& Lessard, E. J. 1987 Effect of fixation on particle retention by microflagellates: underestimation of grazing rates. Marine Ecology Progress Series 38, 251-258

Siver, P. A. \& Chock, J. S. 1986 Phytoplankton dynamics in a chrysophycean lake. In Chrysophytes: Aspects and Problems (Kristiansen, J. \& Andersen, R. A., eds.). Cambridge University Press, Cambridge. pp. 165-183.

Veen, A. 1991 Ecophysiological studies on the phagotrophic phytoflagellate Dinobryon divergens Imhof. Ph.D. thesis, Universiteit van Amsterdam.

Waterbury, J. B., Watson, S. W., Valois, F. W. \& Franks, D. G. 1987 Biological and ecological characterization of the marine unicellular cyanobacterium Synechococcus.

Canadian Journal of Fisheries and Aquatic Sciences 214, 71-120 


\section{CHAPTER 3}

Distribution and Abundance of Mixotrophic Nanoplankton in Nine Adirondack Seepage Ponds and Three Coastal Salt Ponds 


\begin{abstract}
The vertical distributions and abundances of mixotrophic nanoplankton were documented along with other physical, chemical and biological parameters in nine freshwater seepage ponds in the Adirondack Mountains of New York during summer, 1992 and in three coastal salt ponds in Falmouth, Massachusetts, during summer, 1993. The nine freshwater ponds represented a gradient in dissolved organic carbon (DOC) concentration that was hypothesized to influence the distribution and abundance of mixotrophic nanoplankton in these ponds. No clear relationships existed between mixotrophic algal abundance in the Adirondack seepage ponds and the physical, chemical or biological parameters measured. Mixotrophic algae were numerically unimportant in most seepage ponds ( $<5 \%$ of algal nanoplankton). However, $25 \%$ of the total nanoplanktonic algal assemblage was phagotrophic in the upper water column of one pond with moderate concentrations of DOC, and absolute abundances of mixotrophic algae in the metalimnion of this pond were high $\left(\sim 2 \times 10^{4} \mathrm{ml}^{-1}\right)$. Dinobryon was the most important contributor ( $85 \%)$ to the mixotroph assemblage in the metalimnion of this mid DOC pond with peak abundances of $1.7 \times 10^{4} \mathrm{ml}^{-1}$, although only $\sim 50 \%$ of this population $\left(\sim 9 \times 10^{3} \mathrm{ml}^{-1}\right)$ and the Dinobryon population in the epilimnion $\left(\sim 1 \times 10^{3} \mathrm{ml}^{-1}\right)$ were phagotrophically active. Mixotrophic algae were moderately important $(\sim 15 \%)$ in the upper water column of two other ponds with high concentrations of DOC, but mixotroph abundances did not exceed $1 \times 10^{3} \mathrm{ml}^{-1}$.

Documentation of the abundance of mixotrophic nanoplankton in the three coastal salt ponds provide the first evidence for their existence in small semi-enclosed coastal lagoons. Mixotrophic nanoplankton abundances were $<150 \mathrm{ml}^{-1}$ in all three coastal salt ponds examined, and they represented $<2 \%$ of the total nanoplanktonic algal assemblage. While mixotrophy was not common among the nanoplankton assemblage in these small coastal lagoons at the time of study, mixotrophy was prevalent in the microplankton (20-
\end{abstract}


$200 \mu \mathrm{m})$ assemblage in at least one pond. Mixotrophic (chloroplast-bearing) ciliates were present in high abundances $\left(4 \times 10^{4}\right.$ to $\left.>1 \times 10^{5} \mathrm{~L}^{-1}\right)$ throughout the upper water column in one coastal salt pond. The abundance of these "green" ciliates relative to heterotrophic ciliates was highest in surface waters, but their absolute abundances were highest in the metalimnion.

It is clear from this study and others that mixotrophic nanoplankton can be numerically important in some freshwater environments. Interestingly though, mixotrophic nanoplankton abundances in the small coastal lagoons were consistently low during this study. High abundances of microplanktonic mixotrophs in at least one of the coastal ponds, however, suggests that mixotrophy may, on occasion, be more prevalent among the microplankton assemblages in estuarine environments. Energy and nutrient cycling may therefore differ in these environments relative to other marine and some freshwater environments where mixotrophy in the nanoplankton assemblage can be more common. 


\section{INTRODUCTION}

Nanoplanktonic algae (unicellular algae 2-20 $\mu \mathrm{m}$ in size) are important contributors to the phytoplankton assemblage in aquatic environments and are responsible for a significant fraction of primary production (Durbin et al., 1975; Throndsen, 1976; Hallegraeff, 1981; Beers et al., 1982; Ilmavirta, 1983). The algal nanoplankton are typically dominated by members of the Chrysophyceae, Prymnesiophyceae, Cryptophyceae, and Dinophyceae (Ilmavirta, 1983; Estep et al., 1984). Interestingly, each of these flagellate taxa contains several pigmented forms that are capable of phagotrophy in addition to photosynthesis (Sanders \& Porter, 1988). This ability to combine autotrophic and heterotrophic modes of nutrition is known as mixotrophy.

Numerous anecdotal accounts of mixotrophy, from as early as 1911, exist in the literature (Sanders \& Porter, 1988 for a summary of references). Until recently though, the ecological implications of algal phagotrophy in aquatic systems have been largely ignored. However, with recognition of the importance of microheterotrophic processes in energy and nutrient flow through planktonic food webs (Pomeroy, 1974; Azam et al., 1983 ) and methodological developments in the area of microbial ecology (Porter \& Feig, 1980; Caron, 1983; Sherr \& Sherr, 1983; Sherr et al., 1987), ecologists are now beginning to evaluate the role of mixotrophs in aquatic systems.

The nutritional benefits gained from phagotrophy and the conditions under which phagotrophy is employed by algal nanoplankton varies among mixotrophic species. Some mixotrophic species are primarily heterotrophic and rely on phagotrophy to obtain most or all of the organic carbon used for their metabolism and growth (Fenchel, 1982a; Andersson et al., 1989; Sanders et al., 1990). Photosynthesis in these species appears to be used as a mechanism for survival only under poor heterotrophic conditions (i.e., low prey abundance). Other species appear to be obligate mixotrophs (Kimura \& Ishida, 
1986; Caron et al., 1992). In some of these mixotrophic species phagotrophy may serve as a source of specific growth factors required for phototrophic growth (Kimura \& Ishida, 1989). It has also been suggested that phagotrophic behavior may provide some mixotrophic algae with major nutrients (nitrogen or phosphorus) which may be an especially useful strategy during periods of nutrient limitation (Salonen \& Jokinen, 1988). Evidence from several recent studies have provided support for this hypothesis (Nygaard \& Tobiesen, 1993, see also Chapters 2 \& 4).

The potential impact of algal phagotrophy in some systems has been evaluated based on field and laboratory studies. Ingestion rates for some mixotrophic nanoplankton measured in the laboratory have been found to be comparable to ingestion rates of heterotrophs (Fenchel, 1982b; Sherr et al., 1983), and mixotrophic algae have been found to dominate the nanoplankton assemblage on occasion in some aquatic environments (Bird \& Kalff, 1986; Bird \& Kalff, 1987; Porter, 1988; Andersson et al., 1989; Bennett et al., 1990; Sanders et al., 1990). On occasion then, the overall community-level importance of algal phagotrophy has been great, and algal bacterial consumption has been found to exceed consumption by the heterotrophs in some of these plankton communities. For example, in Lake Memphremagog, Vermont-Quebec, ecologists found that the algal phagotroph Dinobryon removed more bacteria from the water column than the crustaceans, rotifers and ciliates combined (Bird \& Kalff, 1986). In another study conducted in surface waters of Lake Oglethorpe, Georgia, grazing by the autotrophic community was found to constitute more than $50 \%$ of total bacterial grazing (Porter, 1988; Sanders et al., 1989).

While these studies have begun to characterize the role of mixotrophic nanoplankton in several aquatic environments, the extent of their distribution and abundance in nature is unclear (Berninger et al., 1992, Chapter 2). This study provides documentation of the distribution and abundance of mixotrophic nanoplankton in a series of nine freshwater seepage ponds in the Adirondack Mountains, NY, and three coastal 
salt ponds in Falmouth, MA, and examines potential relationships between mixotroph abundance and other physical, chemical and biological characteristics of these aquatic systems. The occurrence of mixotrophic nanoplankton in the freshwater seepage ponds was variable and did not appear to be directly related to specific physical, chemical or biological parameters. Mixotrophic nanoplankton abundances were present at high abundances in one freshwater seepage pond, and they accounted for a significant fraction of the algal nanoplankton assemblage. Abundances of mixotrophic nanoplankton were uniformly low in all three coastal salt ponds at the time of study and their contribution in each pond to total abundances of algal nanoplankton was very low. 


\section{METHODS}

Study sites

This work was carried out in nine freshwater seepage ponds in the northwest and west central regions of the Adirondack Mountains of New York during July 1992 and in three coastal salt ponds located adjacent to Vineyard Sound in Falmouth, Massachusetts, during early summer (mid June through late July) 1993. Each freshwater and coastal pond was surveyed once during the study period and the vertical distribution and abundance of phagotrophic algae $2-20 \mu \mathrm{m}$ in size was determined in water samples collected from the surface mixed layer, thermocline and bottom layer at a single station located over the deep basin in each pond. Sampling at each site also included physical profiling, measurement of nutrient concentrations and collection of samples for the determination of microbial population abundances. Water column samples were collected using a $4 \mathrm{~L}$ Van Dorn bottle in the Adirondack seepage ponds and a hand vacuum pump in the Falmouth coastal ponds. Detailed descriptions of the sampling protocols are described below.

\section{Physical characterization of ponds}

Irradiance and temperature profiles for the Adirondack seepage ponds were determined on the day of sampling prior to collection of water samples. Measurements were made at 0.5 or 1 meter intervals from surface to bottom. Irradiance was measured with a Protomatic photometer equipped with upward and downward spherical sensors exposed as hemispheres, and was expressed as a percentage of light energy just below the surface. Temperature profiling was conducted using a YSI model 35 S-C-T meter. The epilimnion, metalimnion and hypolimnion were defined according to the temperature 
structure of the water column (Wetzel, 1975), and served as the basis for determining water column depths for microbial population sampling. Irradiance, temperature and salinity profiles in the Falmouth coastal ponds were determined at $0.5 \mathrm{~m}$ intervals prior to water column sampling. Irradiance was measured with a $4 \pi$ sensor and expressed as a percentage of subsurface light. Temperature and salinity were measured using a YSI model 33 S-C-T meter. Five depths for water column sampling (chlorophyll, nutrients and microbial populations) in each coastal pond were then determined based on their temperature and salinity profiles.

\section{Determination of dissolved oxygen}

Five to six depths were sampled for dissolved oxygen in the Adirondack seepage ponds. Water column samples were fixed in $300 \mathrm{ml}$ BOD bottles at each site, returned to the lab and analyzed using the azide modification of the Winkler titration method (Wetzel, 1991). Concentrations were then converted to \% $\mathrm{O}_{2}$ saturation. A temperature adjustable YSI $\mathrm{O}_{2}$ meter, model $51 \mathrm{~b}$ was used in the Falmouth coastal ponds to obtain profiles of dissolved oxygen concentration with measurements at $0.5 \mathrm{~m}$ intervals. These dissolved oxygen values were converted to $\% \mathrm{O}_{2}$ saturation based on the theoretical concentration for $100 \%$ saturation at the sampling temperature and salinity (Endeco Vapor Program).

\section{Pigment analyses}

Water samples for pigment concentrations were collected from five to eight depths in the Adirondack seepage ponds and placed in the dark prior to their return to the laboratory $(<2 \mathrm{~h})$. Samples were immediately processed back in the lab according to methods outlined in Bukaveckas (1993). Briefly, samples were filtered through Gelman 
A/E glass fiber filters (2-3 L sample-1). Filters were macerated and allowed to extract in $10 \mathrm{ml}$ of aqueous acetone (90\%) for $12 \mathrm{~h}$ in the dark at $4^{\circ} \mathrm{C}$ and then analyzed using a Varion DMS 70 spectrophotometer equipped with $4 \mathrm{~cm}$ cells and a narrow bandwidth (1 $\mathrm{nm})$. Chlorophyll $a$, and phaeophytin concentrations were determined according to the equations of Jeffrey and Humphrey (1975) for mixed phytoplankton populations and the Lorenzen equations as revised by Speziale, et al. (1984).

Water column samples collected from the Falmouth coastal ponds for analysis of chlorophyll, carotenoid and phaeopigment concentrations were immediately placed in cold, dark storage and then returned to the laboratory within two hours. After return to the laboratory, samples were immediately filtered and extracted according to the methods of Parsons et al. (1984). Extractions were analyzed with a Bausch \& Lomb Spectronic 2000 Spectrophotometer and pigment concentrations were determined using spectrophotometric equations (Parsons et al., 1984).

Nutrient analyses

Concentrations of dissolved inorganic nitrogen $\left(\mathrm{NO}_{3}-\mathrm{NH}_{4}{ }^{+}\right)$and phosphorus $\left(\mathrm{PO}_{4}{ }^{-3}\right)$ in the Adirondack seepage ponds were determined from filtered $(0.45 \mu \mathrm{m}$ glass fiber filters), acidified ( $\mathrm{pH} 2.0$ ) water samples collected from a single depth in the epilimnion and a single depth in the hypolimnion. Unfiltered samples from these depths were also collected for analysis of total phosphorus (TP). Samples were stored in the dark at $4^{\circ} \mathrm{C}$ and transported to the Institute of Ecosystems Study Inorganic Laboratory in Millbrook, NY, where they were analyzed. TP analysis was performed according to the molybdenum blue method of Murphy and Riley (1962) after persulfate oxidation. Phenate colorimetric analysis of $\mathrm{NH}_{4}{ }^{+}$was performed by autoanalysis and $\mathrm{PO}_{4}^{-3}$ was analyzed by the molybdenum blue method. $\mathrm{NO}_{3}{ }^{-}$was analyzed by ion exchange chromatography (Small et al., 1975). 
Dissolved inorganic nitrogen $\left(\mathrm{NO}_{3}^{-}, \mathrm{NH}_{4}{ }^{+}\right)$and phosphorus $\left(\mathrm{PO}_{4}^{-3}\right)$ concentrations in each Falmouth coastal pond were determined from water samples that were filtered through $0.22 \mu \mathrm{m}$ Millipore filters immediately upon collection, transported (cold, dark) to the lab and frozen. Prior to analyses samples were thawed to room temperature. Dissolved inorganic phosphate was determined according to the molybdenum blue method of Murphy and Riley (1962). Determination of ammonium was by the indophenol method described by Schiener (1976), and nitrate analyses were done according to Lachat Autoanalysis procedures adapted from techniques in Wood et al. (1967) and Bendschneider (1952).

\section{Determination of microbial population abundances}

Microbial population abundances were determined from duplicate samples collected from one or two depths in the epilimnion, one or two depths in the metalimnion

and a single depth in the hypolimnion of each Adirondack seepage pond and from the five sampling depths in each coastal pond. Subsamples from each depth were preserved immediately with gluteraldehyde at a final concentration of $1 \%$ for microscopical determination of bacterial abundances $(<2 \mu \mathrm{m})$, and phototrophic and heterotrophic nanoplankton abundances (algae and protozoa $2-20 \mu \mathrm{m}$ in size, respectively). Microplankton (algae and protozoa $20-200 \mu \mathrm{m}$ in size, respectively) abundances were also determined in samples from one coastal pond after observations revealed the presence of chloroplast-retaining ciliates in that pond. Population counts were performed by epifluorescence microscopy at 1000x magnification for bacteria and nanoplankton and 400x magnification for microplankton (Porter \& Feig, 1980; Sherr et al., 1993).

Phagotrophic algae were identified in water samples using fluorescently labeled prey as tracers for ingestion. Duplicate water samples from each depth were incubated in clear polycarbonate vessels ( $250 \mathrm{ml}$, seepage ponds; $1 \mathrm{~L}$ coastal ponds) with fluorescently 
labeled bacteria (FLB) prepared from cultures of Pseudomonas halodurans $(\sim 0.8-1.0 \mu \mathrm{m}$ average cell size) according to the method of Sherr et al. (1987). Each vessel was inoculated with FLB within 30 minutes of collection, gently swirled to distribute the tracer and incubated in situ for five hours (between 9am and $4 \mathrm{pm}$ ) at the depth from which they were collected. The density of FLB used in the experiments was chosen such that the tracers could be readily counted, but did not dramatically increase the abundance of natural prey (generally $30-50 \%$ of the natural prey abundance). At the end of the five hour incubation period a final subsample was removed and preserved with $0.05 \% \mathrm{NiCl}_{2}$ followed by $1 \%$ gluteraldehyde (final concentrations) for determination of mixotroph abundance. $\mathrm{NiCl}_{2}$ was added to freshwater samples to prevent possible egestion of the tracers, but not to coastal pond samples because $\mathrm{NiCl}_{2}$ causes cells in seawater to clump (J.B. Waterbury, WHOI, pers. comm.).

Two hundred to four hundred individual phototrophic nanoplankton (chloroplastbearing cells $2-20 \mu \mathrm{m}$ in size) in each sample were examined by epifluorescence microscopy for ingested fluorescently labeled prey. Mixotrophic nanoplankton (MNAN) were operationally defined as cells containing autofluorescent chloroplasts and ingested fluorescently labeled prey. The relative abundance of mixotrophic nanoplankton was determined as a percentage of the phototrophic nanoplankton. These percentages were then converted to absolute abundances of mixotrophic nanoplankton based on the abundances of phototrophic nanoplankton in the samples. This method for determining the abundance of mixotrophic nanoplankton was based on two assumptions: (1) fluorescently labeled prey were ingested at the same rate as natural prey, and (2) all MNAN actively phagocytized prey during experiments. This method therefore provided a lower limit estimate of the actual abundance of mixotrophic nanoplankton present in water samples since some mixotrophic cells may not have phagocytized prey during experiments. At present there is no other way to establish the presence of mixotrophs in natural samples. 
Statistics

Correlation coefficients and their $t$ statistics for the freshwater seepage ponds were determined for all pairwise variables from each pond. Significant relationships between pairs of variables reported in the text are based on a test of $\mathrm{H}_{\mathrm{O}}: r=0$ using the two-sided $t$ test with $n-2$ degrees of freedom at $a$ level $=0.05$. 


\section{RESULTS}

\section{Freshwater Seepage Ponds}

The nine freshwater seepage ponds chosen for this study were previously found to represent a gradient in dissolved organic carbon (DOC) concentration (Saunders, 1992, See Table 3.1 for site descriptions). The low DOC $\left(<3 \mathrm{mg} \mathrm{L}^{-1}\right)$ and mid DOC $(5-7 \mathrm{mg} \mathrm{L}$ ${ }^{1}$ ) ponds in this study were typified by circum-neutral $\mathrm{pH}$ values between 5.5 and 6.25 , while high DOC ponds (15-24 mg L-1) were generally more acidic with $\mathrm{pH}$ values slightly greater than 4 (Saunders, 1992).

\section{Physical characteristics}

Saunders (1992) found that epilimnetic mixing depths were more shallow in the ponds with high DOC concentrations. Thermal stratification was evident in eight of the nine seepage ponds at the time of this study and the shallowest epilimnetic mixing depths were also associated with high DOC ponds (Fig 3.1). Round Pond (low DOC) was well mixed to the bottom (Fig. 3.1a). Epilimnetic mixing extended down to approximately 4 $\mathrm{m}$ in the two weakly stratified low DOC ponds (Fig. $3.1 \mathrm{~b}, \mathrm{c}$ ), to $2 \mathrm{~m}$ in the mid DOC ponds (Fig. 3.1d-f) and to $0.5-1 \mathrm{~m}$ in the high DOC ponds (Fig. 3.1g-i).

Light attenuation rates in these ponds were previously found to be related to epilimnetic DOC concentration (Saunders, 1992). This relationship was apparent during this study. Light intensity at the bottom of Round Pond was $>5 \%$ of subsurface irradiance (Fig. 3.2a). The depth of $1 \%$ subsurface light in the other two low DOC ponds occurred below the base of the thermocline (Deer Pond, 8m, Fig 3.2b; Pitchfork Pond, $6 \mathrm{~m}$, Fig. 3.2c). The depth of $1 \%$ subsurface light also corresponded with the base of the 
Table 3.1. Freshwater seepage pond and coastal salt pond surface areas, basin depths and dissolved organic carbon concentrations (freshwater ponds only). Information for freshwater seepage ponds taken from Saunders (1992). Data for coastal salt ponds taken from Giblin (1990).

Site Name

Surface Area Basin Depth

DOC (ha)

(m) $\quad\left(\mathrm{mg} \mathrm{L}^{-1}\right)$

Freshwater Seepage Ponds

Low DOC

Round

Deer

Pitchfork

4

10

16

7

14

0.1

8

1.4

2.8

Mid DOC

Wheeler

Kanacto

6

4

Rat

12

18

15

5.7

6.9

6.9

High DOC

Amphitheater

Fox

Little Echo

1
1
1

6

24.5

15.1

10

18.8

Coastal Salt Ponds

Perch

7

Oyster

25

Salt

29

3

4

6
$-$

$-$

$--$ 

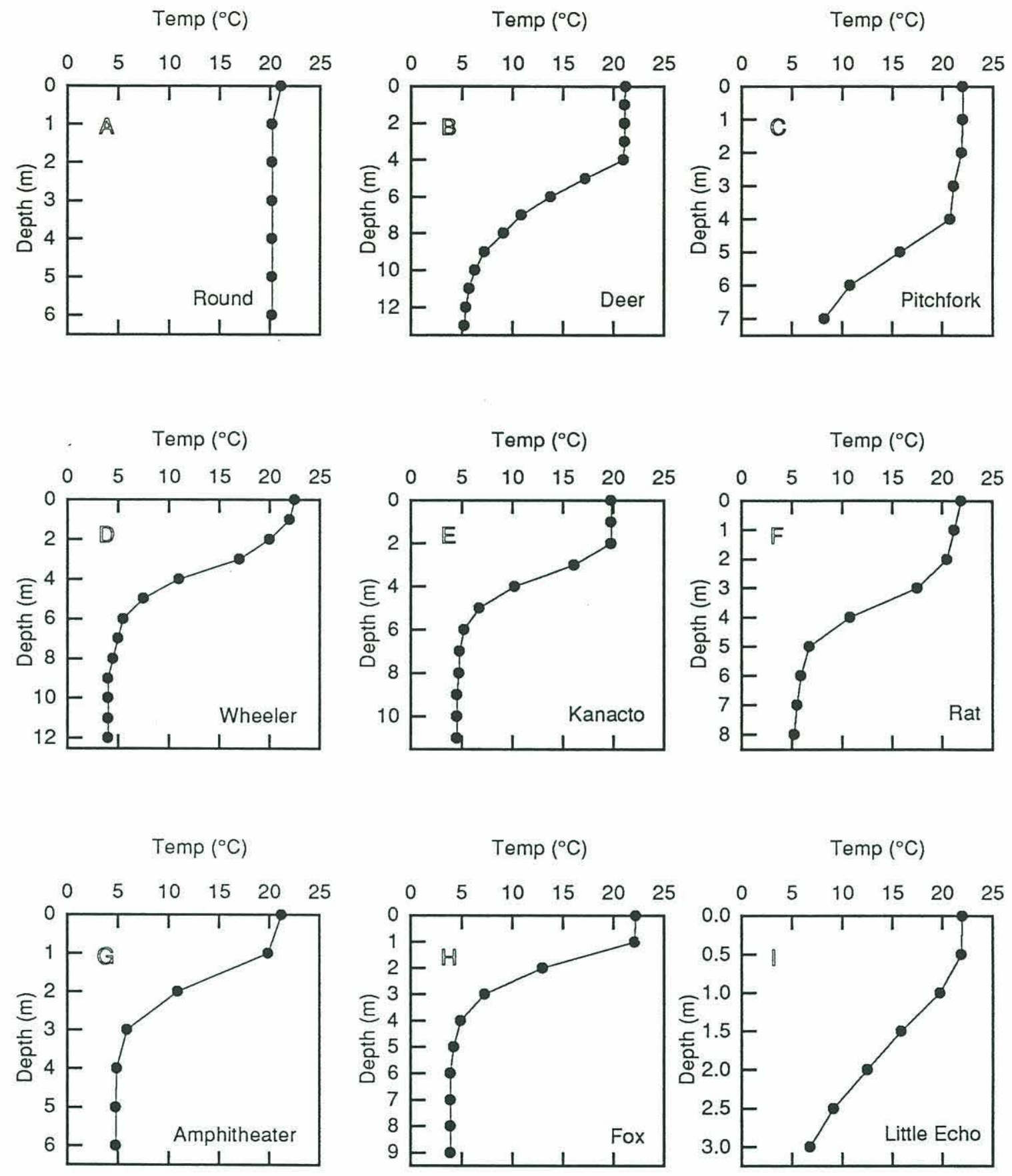

Figure 3.1. Vertical profiles of temperature in low DOC (A-C), mid DOC (D-F) and high DOC (G-I) seepage ponds in the northwest and west central regions of the Adirondack Mountains, NY during July 1992. 

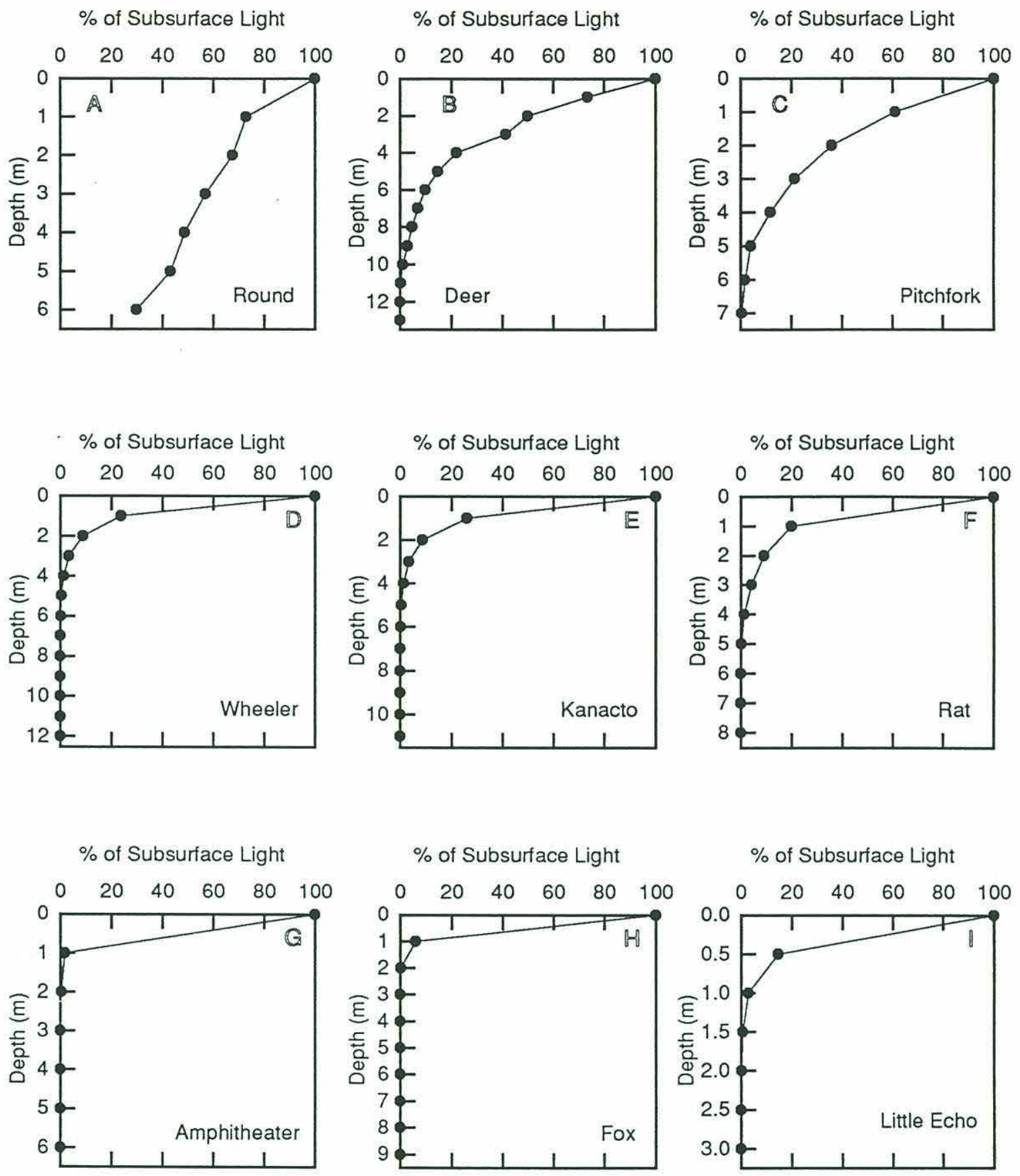

Figure 3.2. Vertical profiles of light in low DOC (A-C), mid DOC (D-F) and high DOC (G-I) seepage ponds in the northwest and west central regions of the Adirondack Mountains, NY during July 1992. 
thermocline in all three mid DOC ponds ( $4 \mathrm{~m}$, Fig. 3.2d-f), but occurred near the top of the thermocline in the high DOC ponds (1 m, Fig. $3.2 \mathrm{~g}-\mathrm{i})$.

$\%$ oxygen saturation

Eight of the nine seepage ponds had little or no oxygen in their hypolimnia (Fig. 3.3). Of these eight sites, four had anoxic hypolimnia. These included two mid DOC ponds (Fig. 3.3e, f) and two high DOC ponds (Fig. 3.3g, h). Oxygen concentrations in the epilimnia of the three high DOC ponds were significantly below saturation $(<65 \%)$. In Deer Pond, oxygen supersaturation was measured in the mid-metalimnion. Supersaturation at this depth was a consistent feature in this pond throughout the summer during the earlier study by Saunders (1992).

Pigments

Most of the ponds in this study are classified as meso-oligotrophic by the Adirondack Lakes Survey Corporation according to upper water column chlorophyll $a$ concentration (Likens, 1975; Fig. 3.4b-i). Round Pond is considered oligotrophic based on the occurrence of low chlorophyll $a$ concentrations throughout the water column (<1.3-3.2 $\mu \mathrm{g} \mathrm{L}^{-1}$; Fig. 3.4a). Deep chlorophyll maxima (DCM) were evident in four of the nine seepage ponds. These maxima generally occurred at the base of the metalimnia, and chlorophyll $a$ concentrations were considerably greater at these depths than average chlorophyll $a$ concentrations in the epilimnia. Concentrations of chlorophyll $a$ in the DCM of Pitchfork Pond and Rat Pond were between 27 and $33 \mu \mathrm{g} \mathrm{L}-1$ (Fig. 3.4c, f). In Little Echo Pond, chlorophyll $a$ concentration was nearly $50 \mu \mathrm{g} \mathrm{L}^{-1}$ in the DCM (Fig. 3.4i). Chlorophyll $a$ concentration in the DCM at Deer Pond approached $70 \mu \mathrm{L} \mathrm{L}^{-1}$ (Fig. $3.4 b)$. 

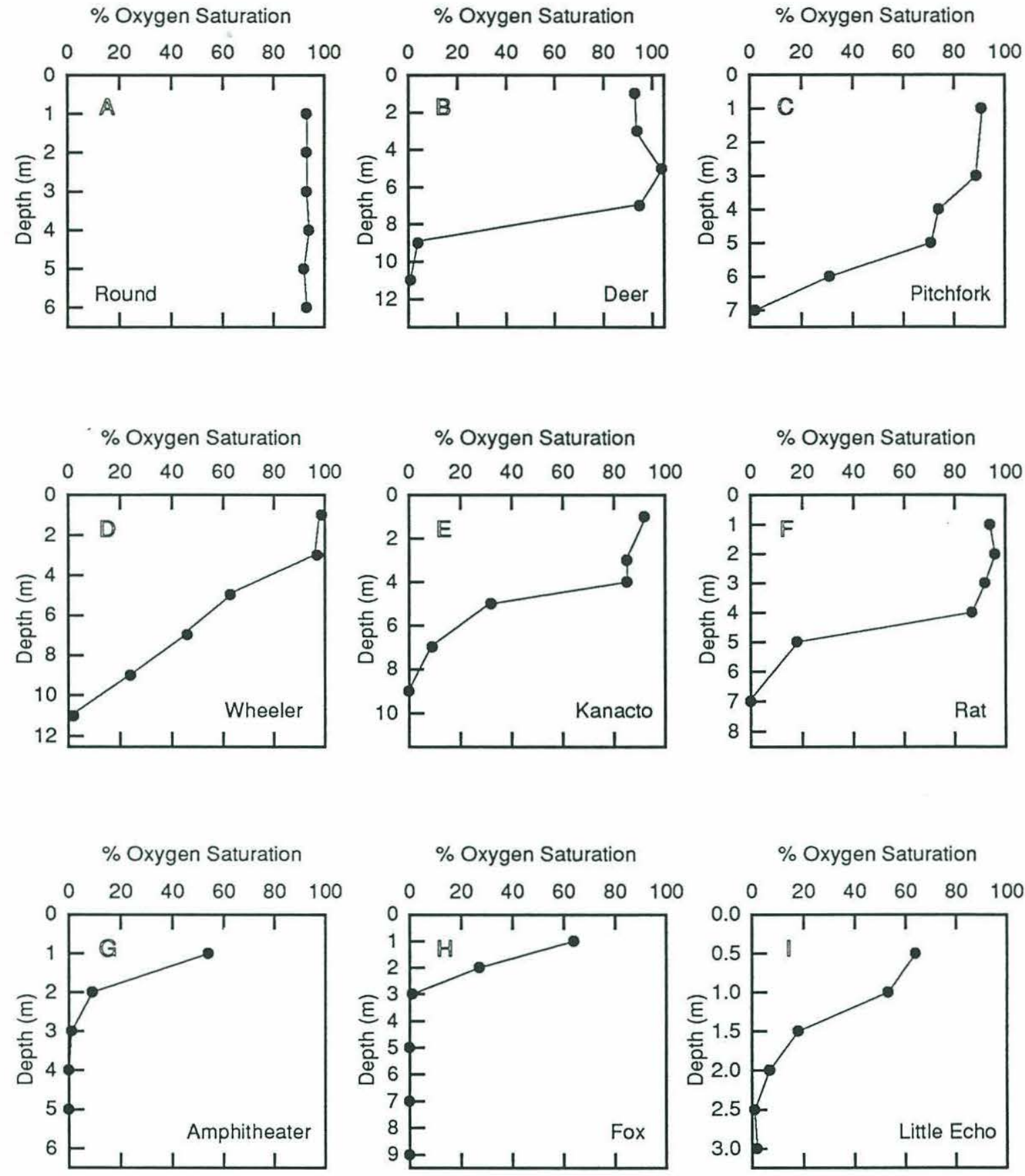

Figure 3.3. Vertical profiles of \% oxygen saturation in low DOC (A-C), mid DOC (D-F) and high DOC (G-I) seepage ponds in the northwest and west central regions of the Adirondack Mountains, NY during July 1992. 


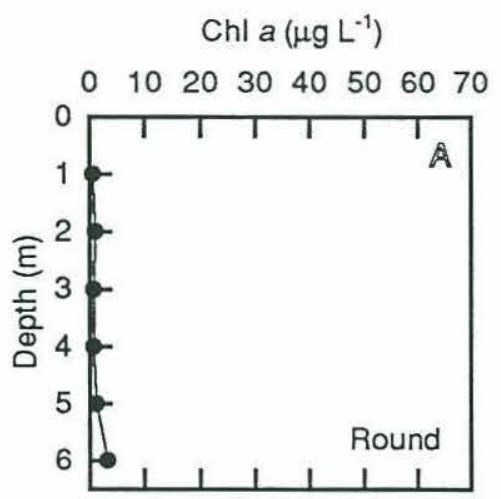

Chl a $\left(\mu \mathrm{g} \mathrm{L}^{-1}\right)$

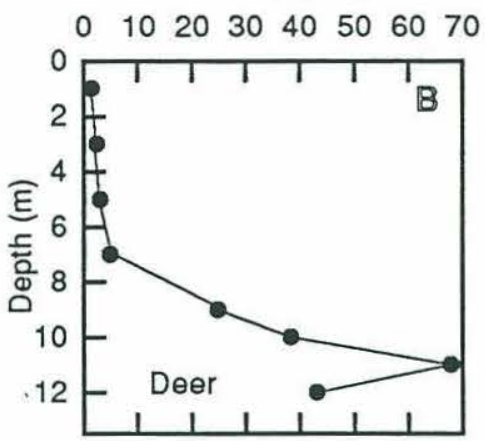

Chl a $\left(\mu \mathrm{g} \mathrm{L}^{-1}\right)$

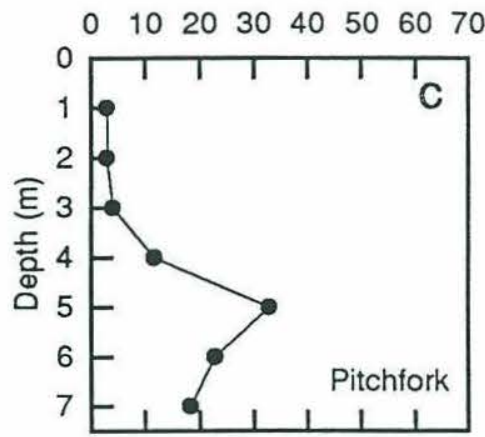

Chl a $\left(\mu \mathrm{g} \mathrm{L}^{-1}\right)$

$\begin{array}{llllllll}0 & 10 & 20 & 30 & 40 & 50 & 60 & 70\end{array}$

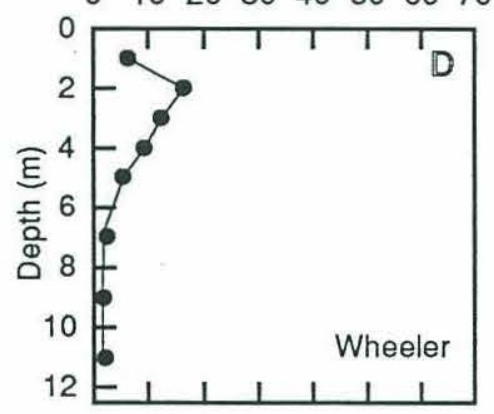

$\mathrm{Chl}$ a $\left(\mu \mathrm{g} \mathrm{L}^{-1}\right)$

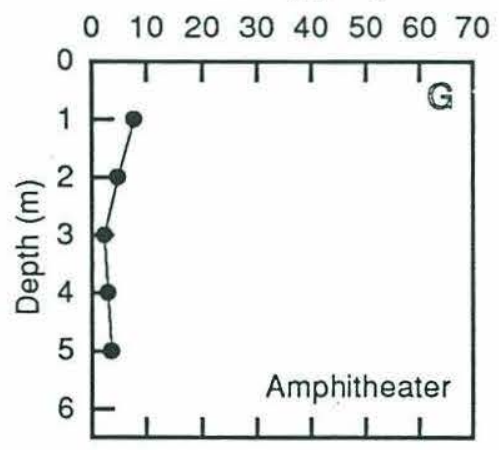

$\mathrm{Chl} \mathrm{a}\left(\mu \mathrm{g} \mathrm{L}^{-1}\right)$

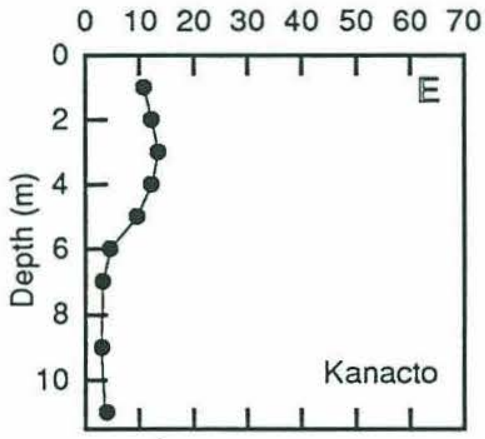

$\mathrm{Chl} a\left(\mu \mathrm{g} \mathrm{L}^{-1}\right)$

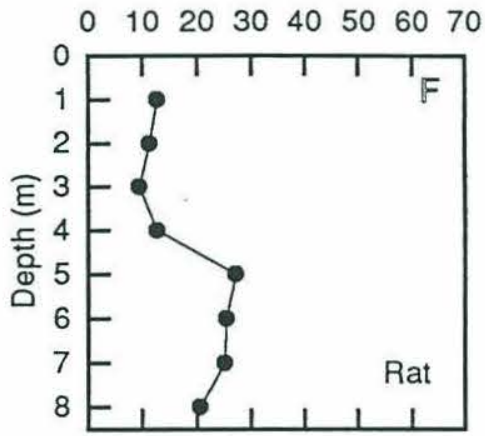

Figure 3.4. Vertical profiles of chlorophyll $a$ concentration in low DOC (A-C), mid DOC (D-F) and high DOC (G-I) seepage ponds in the northwest and west central regions of the Adirondack Mountains, NY during July 1992. 
Nutrients

Ammonium was the dominant form of dissolved inorganic nitrogen in the epilimnia of all nine seepage ponds and in the hypolimnia of eight of the nine seepage ponds. Epilimnetic $\mathrm{NH}_{4}{ }^{+}$concentrations were positively correlated with DOC concentration (Fig. 3.5a) and ranged from 3.3-16.1 $\mu \mathrm{M} \mathrm{NH}_{4}{ }^{+}$(Table 3.2). $\mathrm{NH}_{4}{ }^{+}$ concentrations were generally higher in the hypolimnia $\left(1.7-41.7 \mu \mathrm{M} \mathrm{NH}_{4}^{+}\right)$. Nitrate concentrations in the epilimnia of Wheeler Pond and Fox Pond were $1.3 \mu \mathrm{M}$ and $1.6 \mu \mathrm{M}$, respectively. Epilimnetic $\mathrm{NO}_{3}^{-}$was undetectable in the other seven seepage ponds $(<0.3$ $\mu \mathrm{M}) . \mathrm{NO}_{3}$ - was also undetectable in the hypolimnia of all of the ponds except in the hypolimnion of Wheeler Pond where $\mathrm{NO}_{3}^{-}$was the dominant form of inorganic nitrogen (15.7 $\mu \mathrm{M} \mathrm{NO}_{3}{ }^{-}$compared to $5.6 \mu \mathrm{M} \mathrm{NH}_{4}{ }^{+}$).

Dissolved inorganic phosphorus $\left(\mathrm{PO}_{4}^{-3}\right)$ and total phosphorus (TP) concentrations were generally higher in the hypolimnia than in the epilimnia (Table 3.2). Hypolimnetic $\mathrm{PO}_{4}^{-3}$ concentrations in the nine ponds ranged from $0.10-1.11 \mu \mathrm{MPO}_{4}{ }^{-3}$. TP concentrations in the hypolimnia ranged from 0.13-1.96 $\mu \mathrm{M}$ TP. Epilimnetic $\mathrm{PO}_{4}{ }^{-3}$ and TP concentrations were found to be positively correlated with DOC concentration in the

ponds (Fig. 3.5b, c). Epilimnetic $\mathrm{PO}_{4}{ }^{-3}$ and TP concentrations ranged from 0.11-0.23 $\mu \mathrm{M}$ $\mathrm{PO}_{4}{ }^{-3}$ and from $0.13-0.29 \mu \mathrm{M}$ TP in the low DOC ponds, from $0.23-0.41 \mu \mathrm{M} \mathrm{PO}_{4}{ }^{-3}$ and 0.37-0.44 $\mu \mathrm{M}$ TP in the mid DOC pond, and from $0.20-0.46 \mu \mathrm{M} \mathrm{PO}_{4}{ }^{-3}$ and $0.44-0.50 \mu \mathrm{M}$ TP in the high DOC ponds.

\section{Microbial population abundances}

Bacterial abundances (BACT) in the hypolimnia of five of the nine seepage ponds were significantly higher than bacterial abundances in the epilimnia of these ponds, and hypolimnetic abundances ranged from $>5 \times 10^{6}$ to $\sim 1.7 \times 10^{7}$ BACT ml-1 $^{-1}$ (Fig. 3.6b, c, f, g). 

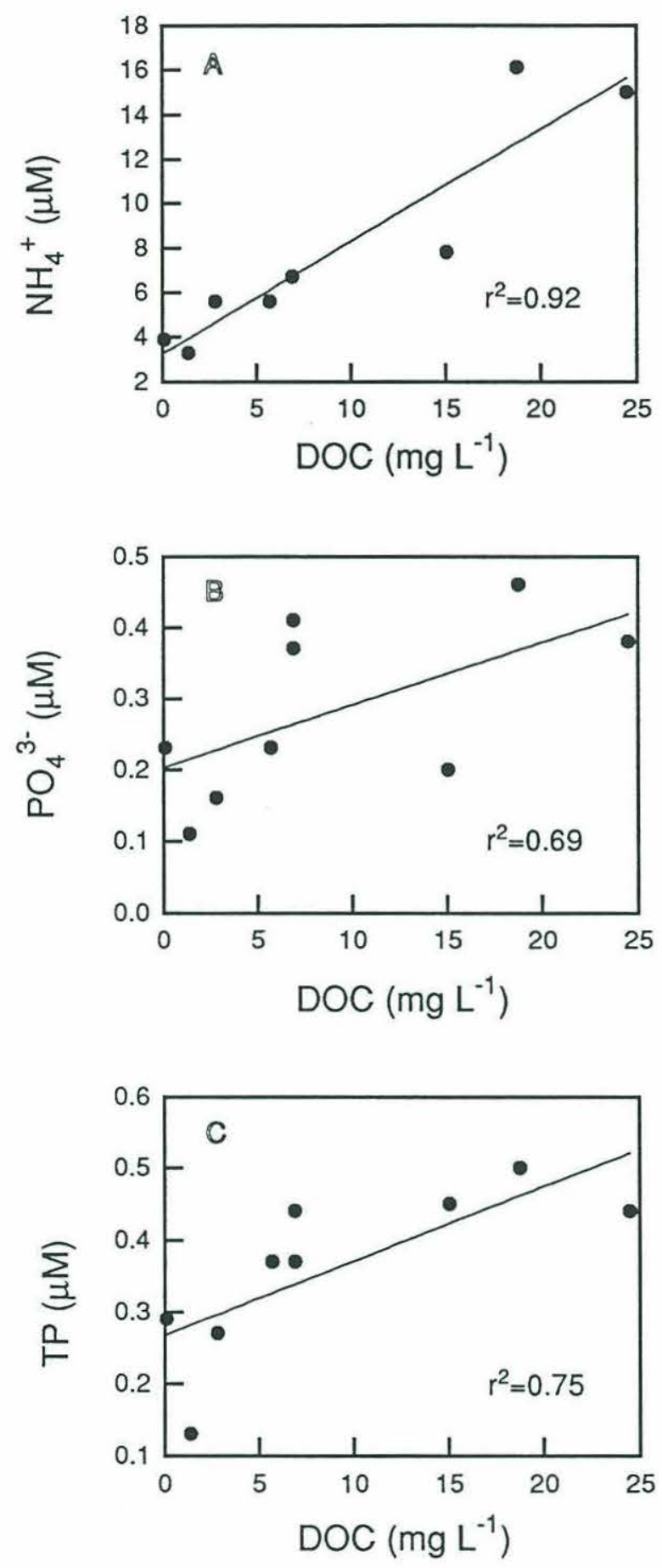

Figure 3.5. The correlation between dissolved organic carbon concentration (DOC) and epilimnetic concentrations of ammonium (A), dissolved phosphate (B) and total phosphorus (C) in nine Adirondack seepage ponds during July 1992. 
Table 3.2. Nutrient concentrations during July 1992 in epilimnetic and hypolimnetic water samples collected from low DOC seepage ponds (Round, Deer and Pitchfork), mid DOC seepage ponds (Wheeler, Kanacto and Rat) and high DOC seepage ponds (Amphitheater, Fox and Little Echo) located in the northwest and west central regions of the Adirondack Mountains, NY.

\begin{tabular}{|c|c|c|c|c|c|c|}
\hline Pond & Date & $\begin{array}{l}\text { Depth } \\
\text { (m) }\end{array}$ & $\begin{array}{l}\mathrm{NH}_{4} \\
(\mu \mathrm{M})\end{array}$ & $\begin{array}{l}\mathrm{NO}_{3} \\
(\mu \mathrm{M})\end{array}$ & $\begin{array}{c}\mathrm{SRP}(\mathrm{PO} 4) \\
(\mu \mathrm{M})\end{array}$ & $\begin{array}{c}\text { TP } \\
(\mu \mathrm{M})\end{array}$ \\
\hline ROUND & $7 / 16 / 92$ & $\begin{array}{l}1 \\
5\end{array}$ & $\begin{array}{l}3.3 \\
1.7\end{array}$ & $\begin{array}{l}<0.3 \\
<0.3\end{array}$ & $\begin{array}{l}0.11 \\
0.10\end{array}$ & $\begin{array}{l}0.13 \\
0.19\end{array}$ \\
\hline DEER & $7 / 29 / 92$ & $\begin{array}{c}3 \\
11\end{array}$ & $\begin{array}{r}5.6 \\
30.0\end{array}$ & $\begin{array}{l}<0.3 \\
<0.3\end{array}$ & $\begin{array}{l}0.16 \\
0.49\end{array}$ & $\begin{array}{l}0.27 \\
1.50\end{array}$ \\
\hline PITCHFORK & $7 / 20 / 92$ & $\begin{array}{l}3 \\
7\end{array}$ & $\begin{array}{r}3.9 \\
13.9\end{array}$ & $\begin{array}{l}<0.3 \\
<0.3\end{array}$ & $\begin{array}{l}0.23 \\
0.58\end{array}$ & $\begin{array}{l}0.29 \\
1.96\end{array}$ \\
\hline WHEELER & $7 / 19 / 92$ & $\begin{array}{l}1 \\
9\end{array}$ & $\begin{array}{l}5.6 \\
5.6\end{array}$ & $\begin{array}{r}1.3 \\
15.7\end{array}$ & $\begin{array}{l}0.23 \\
0.22\end{array}$ & $\begin{array}{l}0.37 \\
0.32\end{array}$ \\
\hline KANACTO & $7 / 14 / 92$ & $\begin{array}{l}1 \\
5\end{array}$ & $\begin{array}{r}6.7 \\
35.0\end{array}$ & $\begin{array}{l}<0.3 \\
<0.3\end{array}$ & $\begin{array}{l}0.37 \\
0.49\end{array}$ & $\begin{array}{l}0.37 \\
0.60\end{array}$ \\
\hline RAT & $7 / 18 / 92$ & $\begin{array}{l}1 \\
5\end{array}$ & $\begin{array}{r}6.7 \\
18.9\end{array}$ & $\begin{array}{l}<0.3 \\
<0.3\end{array}$ & $\begin{array}{l}0.41 \\
0.44\end{array}$ & $\begin{array}{l}0.44 \\
1.52\end{array}$ \\
\hline AMPHITHEATER & $7 / 22 / 92$ & $\begin{array}{l}1 \\
3\end{array}$ & $\begin{array}{l}15.0 \\
13.3\end{array}$ & $\begin{array}{l}<0.3 \\
<0.3\end{array}$ & $\begin{array}{l}0.38 \\
0.65\end{array}$ & $\begin{array}{l}0.44 \\
0.69\end{array}$ \\
\hline FOX & $7 / 21 / 92$ & $\begin{array}{l}1 \\
7\end{array}$ & $\begin{array}{r}7.8 \\
41.7\end{array}$ & $\begin{array}{r}1.6 \\
<0.3\end{array}$ & $\begin{array}{l}0.20 \\
1.11\end{array}$ & $\begin{array}{l}0.45 \\
1.32\end{array}$ \\
\hline LITTLE ECHO & $7 / 17 / 92$ & $\begin{array}{l}1 \\
3\end{array}$ & $\begin{array}{l}16.1 \\
25.0\end{array}$ & $\begin{array}{l}<0.3 \\
<0.3\end{array}$ & $\begin{array}{l}0.46 \\
1.08\end{array}$ & $\begin{array}{l}0.50 \\
1.74\end{array}$ \\
\hline
\end{tabular}



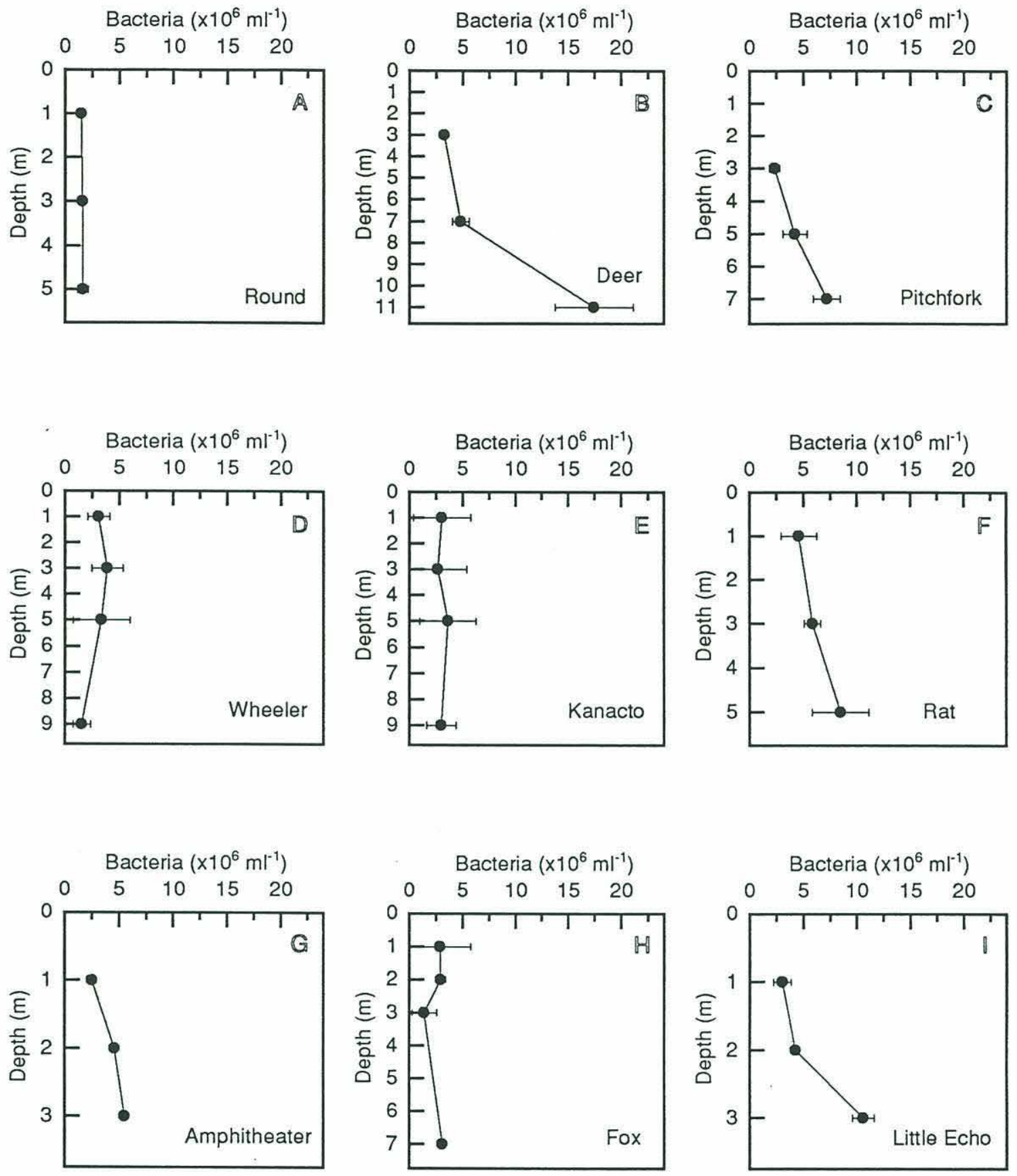

Figure 3.6. Vertical profiles of bacterial abundance $( \pm 1 \mathrm{SD})$ in low DOC (A-C), mid DOC (D-F) and high DOC (G-I) seepage ponds in the northwest and west central regions of the Adirondack Mountains, NY during July 1992. 
Bacterial abundances (BACT) remained relatively constant with depth $\left(\sim 2 \times 10^{6}\right.$ to $\sim 5 \times 10^{6}$ BACT ml-1; Fig. 3.7a, d, e, h) in Round Pond, Fox Pond and two mid DOC ponds. Nevertheless, a weak, but significant, correlation existed between bacterial abundance and temperature, \% of subsurface light and dissolved oxygen (Fig. 3.7). Bacterial abundance was positively correlated with heterotrophic nanoplankton (HNAN) abundance (Fig 3.8). Upper water column (epilimnion \& metalimnion) HNAN abundances in the ponds ranged from $<1 \times 10^{4}$ to nearly $4 \times 10^{4} \mathrm{HNAN} \mathrm{ml}^{-1}$, whereas hypolimnetic HNAN abundances ranged from $<1 \times 10^{4}$ to $~ 9 \times 10^{4} \mathrm{HNAN} \mathrm{ml}^{-1}$ (Fig. 3.9).

A significant, although weak, negative correlation was observed between phototrophic nanoplankton (PNAN) abundance and DOC concentration in the ponds (Fig. 3.10a). In addition, significant, but weak, negative correlations were found between upper water column PNAN abundance and epilimnetic $\mathrm{NH}_{4}+, \mathrm{PO}_{4}{ }^{-3}$ and TP concentration (Fig. 3.10b, c, d). The depth distribution of PNAN, however, did not appear to be related to pond DOC concentration. PNAN abundances in Round Pond, which was very clear and well mixed to the bottom, increased with depth (Fig. 3.11a). PNAN abundances ranged from $\sim 1.3 \times 10^{4} \mathrm{ml}^{-1}$ in the epilimnion to $2.3 \times 10^{4} \mathrm{ml}^{-1}$ in the hypolimnion. Subsurface peaks in PNAN abundance that ranged from $<2 \times 10^{4}$ to $>4 \times 10^{4}$ PNAN ml-1 occurred in Deer, Pitchfork, Wheeler, Fox and Little Echo Ponds (Fig. 3.11b$\mathrm{d}, \mathrm{h}, \mathrm{i})$. PNAN abundances did not change greatly with depth in Rat Pond $\left(\sim 1.7 \times 10^{4}\right.$

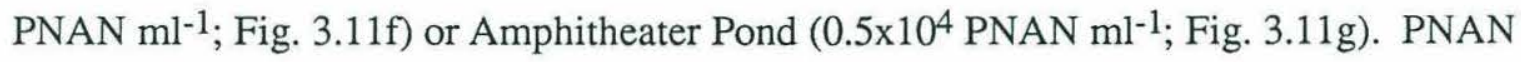
abundances were also relatively constant in the upper water column of Kanacto Pond $\left(\sim 2 \times 104\right.$ PNAN ml-1), but decreased significantly in the hypolimnion $\left(<0.5 \times 10^{4}\right.$ PNAN $\mathrm{ml}^{-1}$; Fig. 3.11e).

Both solitary and colonial forms of unicellular algae were observed in most ponds. All solitary algae were considered as a single group (solitary PNAN) during this study. No attempt was made to distinguish individual species or genera of solitary algae due to difficulties in identifying cellular features using epifluorescence microscopy. The 

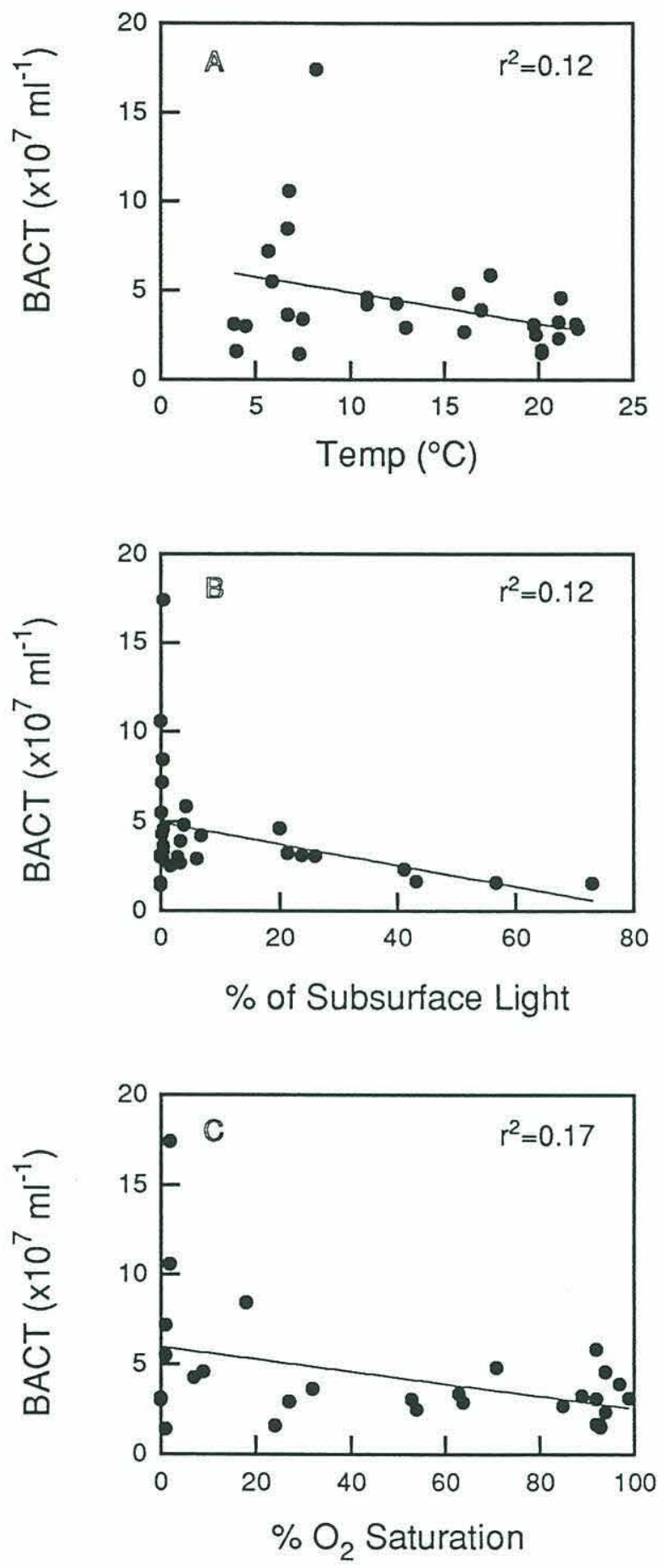

Figure 3.7. Correlations between bacterial abundance (BACT) and temperature (A), $\%$ of subsurface light (B), and \% oxygen saturation (C) in nine Adirondack seepage ponds during July 1992. 


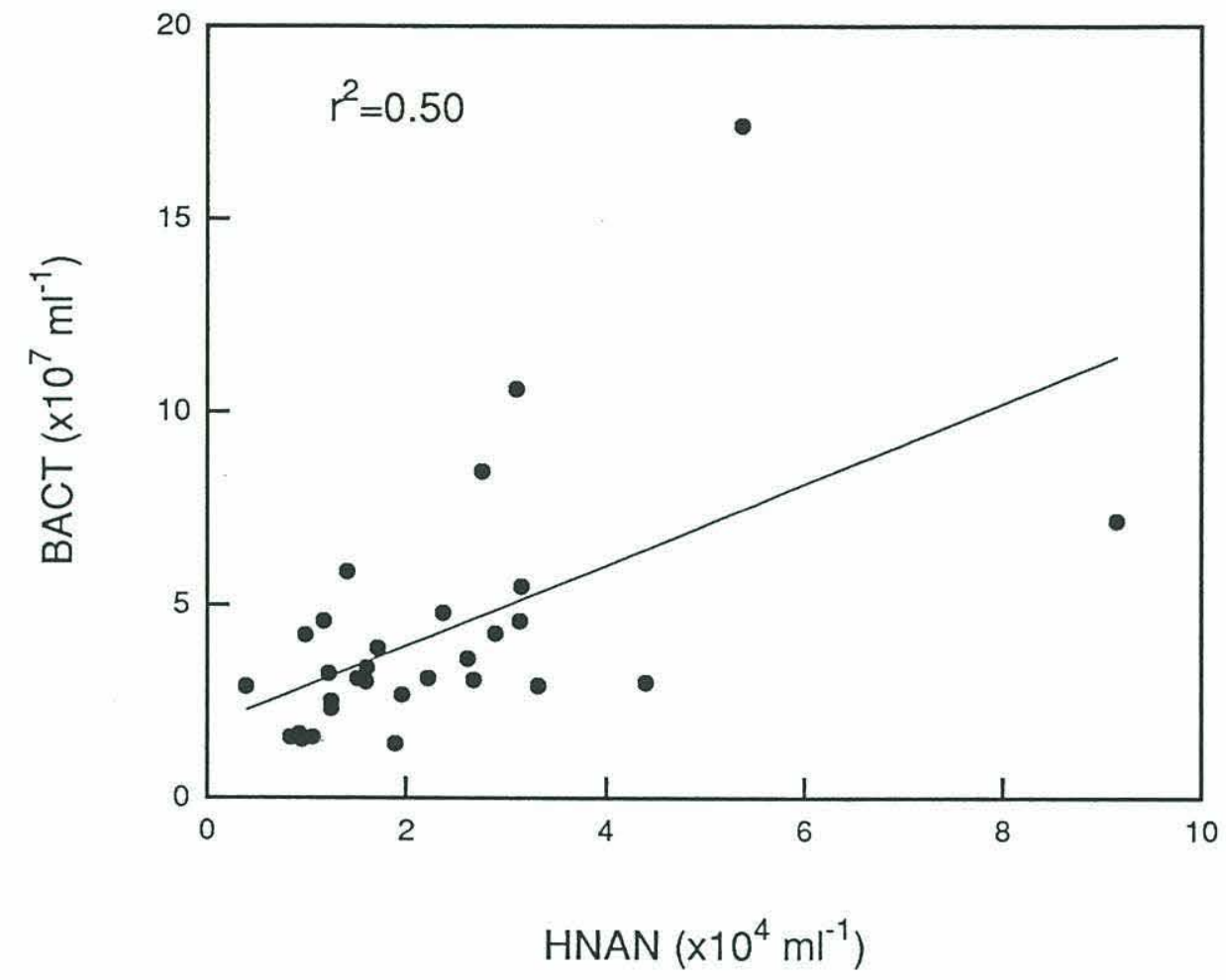

Figure 3.8. The correlation between bacterial abundance (BACT) and heterotrophic nanoplankton abundance (HNAN) for nine Adirondack seepage ponds during July 1992. 

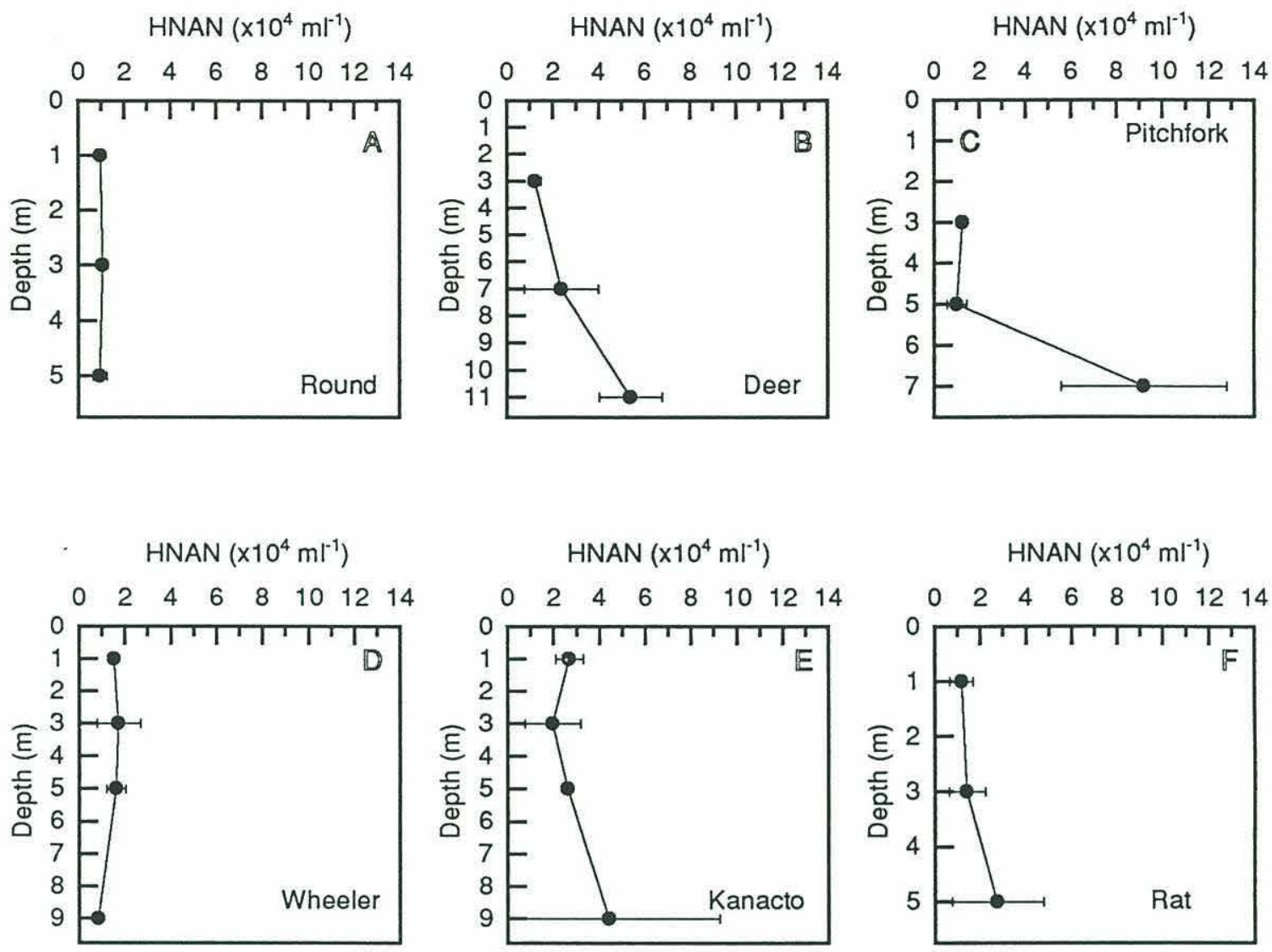

HNAN $\left(\times 10^{4} \mathrm{ml}^{-1}\right)$

HNAN $\left(\times 10^{4} \mathrm{ml}^{-1}\right)$

HNAN $\left(\times 10^{4} \mathrm{ml}^{-1}\right)$
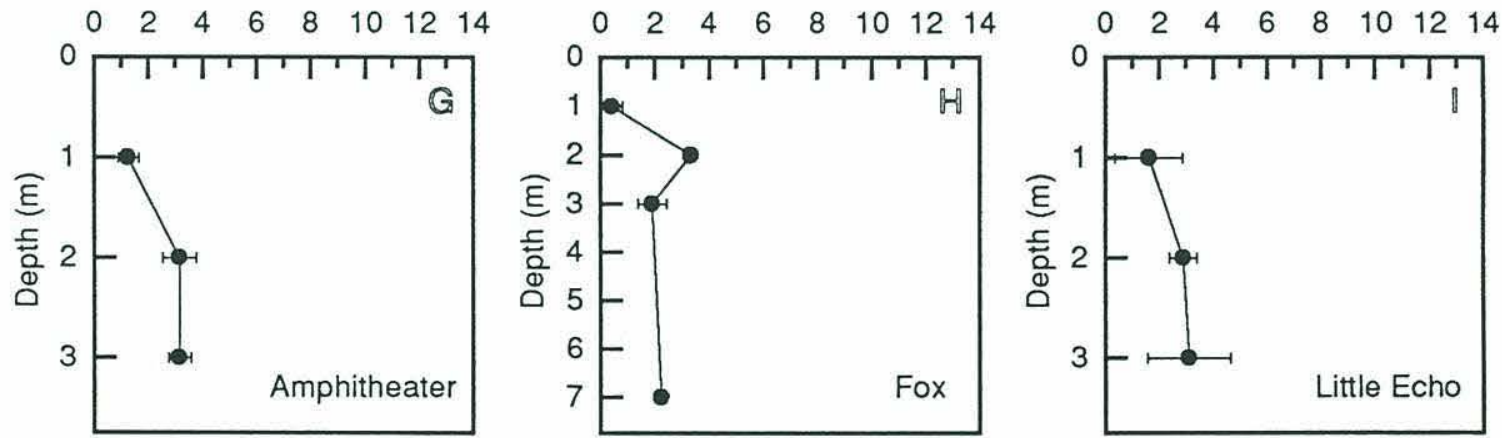

Figure 3.9. Vertical profiles of heterotrophic nanoplankton (HNAN) abundances $( \pm 1$ SD) in low DOC (A-C), mid DOC (D-F) and high DOC (G-I) seepage ponds in the northwest and west central regions of the Adirondack Mountains, NY during July 1992. 

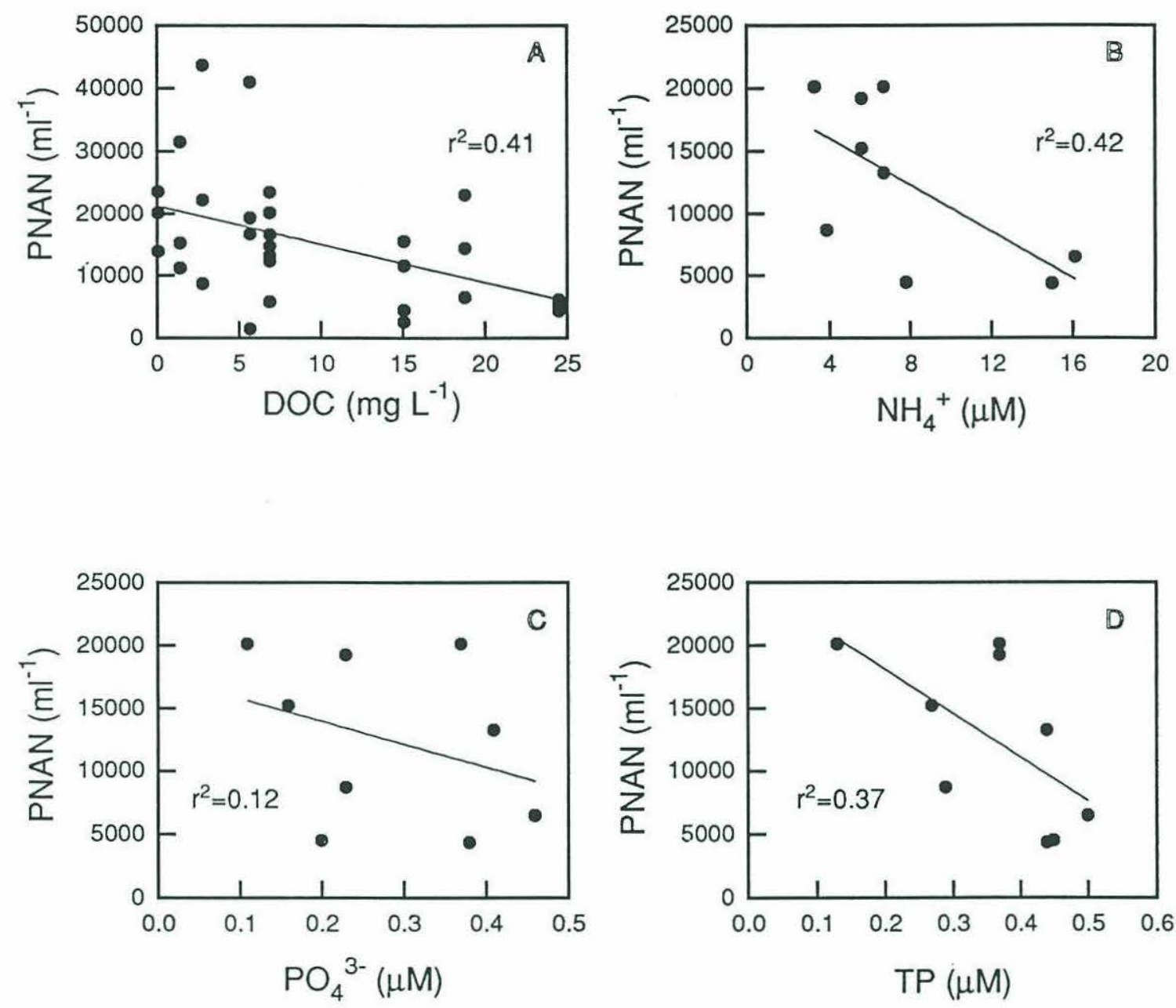

Figure 3.10. Correlations between epilimnetic, metalimnetic and hypolimnetic phototrophic nanoplankton abundance and DOC concentration (A), and between epilimnetic phototrophic nanoplankton abundance and epilimnetic ammonium (B), dissolved phosphate (C) and total phosphorus (D) concentrations in nine Adirondack seepage ponds during July 1992. 

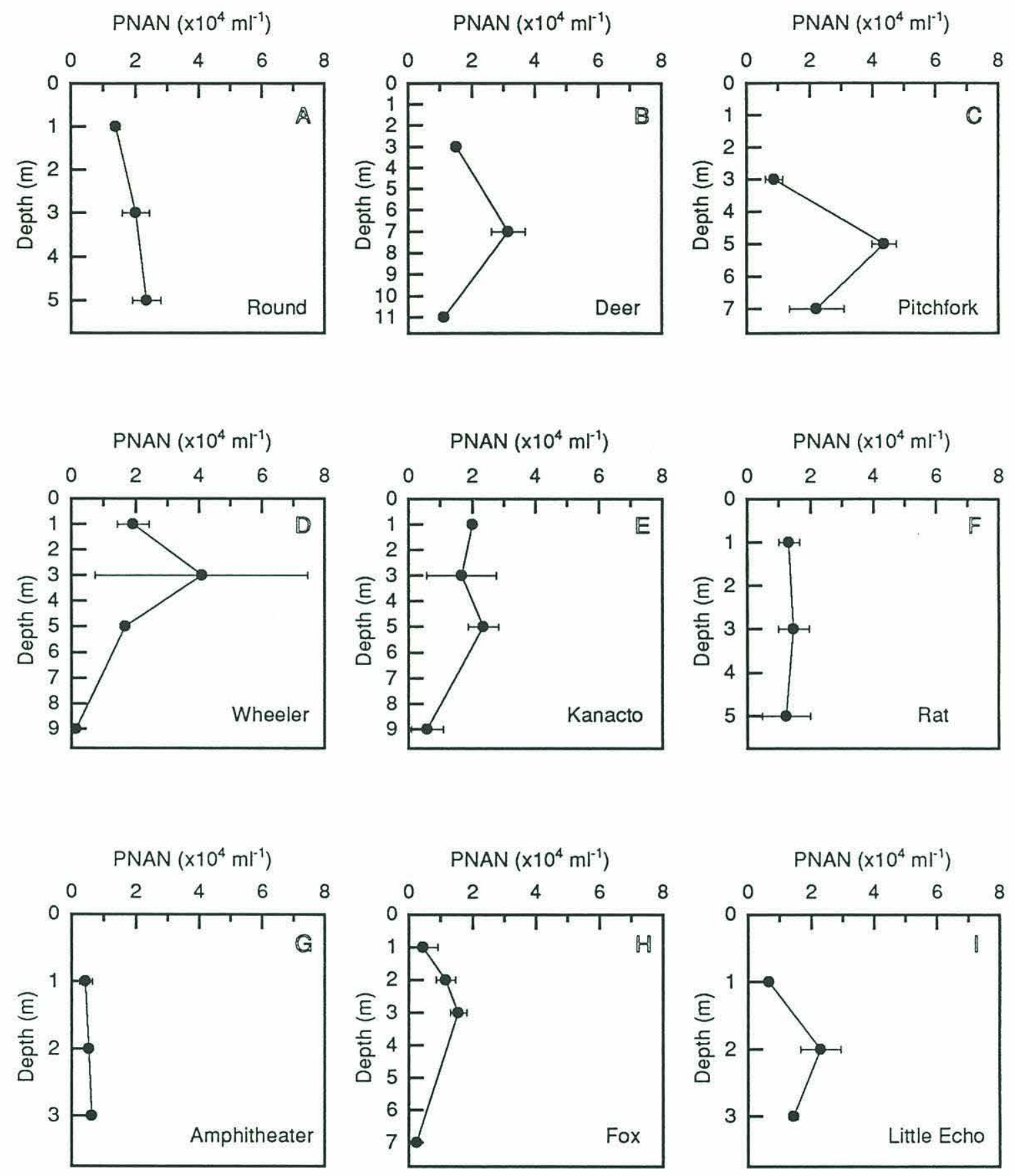

Figure 3.11. Vertical profiles of phototrophic nanoplankton (PNAN) abundance $( \pm 1$ SD) in low DOC (A-C), mid DOC (D-F) and high DOC (G-I) seepage ponds in the northwest and west central regions of the Adirondack Mountains, NY during July 1992. 
colonial chrysophyte Dinobryon was clearly identified by the presence of its distinct lorica, however. Dinobryon, a known mixotroph, was therefore counted separately from other colonial algae (Colonial PNAN). Solitary algal abundances ranged from $<0.5 \times 10^{4}$ $\mathrm{ml}^{-1}$ to nearly $3 \times 10^{4} \mathrm{ml}^{-1}$ (Fig. 3.12), and dominated the phototrophic nanoplankton $(>50 \%)$ in the epilimnion, metalimnion and hypolimnion in seven of the nine seepage ponds. Solitary forms were the principal component of most of the subsurface PNAN peaks that were observed in some of the ponds (Fig. 3.12b, h, i), but colonial forms of algae dominated the subsurface PNAN peaks in two of the ponds. Greater than $70 \%$ of the metalimnetic PNAN populations in Pitchfork Pond and Wheeler Pond were colonial algae. Unidentified colonial algae dominated $\left(\sim 3 \times 10^{4} \mathrm{ml}^{-1}\right)$ in the metalimnion of Pitchfork Pond (Fig. 3.12c), but the mixotrophic colonial chrysophyte Dinobryon was the largest overall contributor (42\% of PNAN abundance) to the PNAN assemblage in the mid-metalimnion of Wheeler Pond and abundances were high ( 1.7 $\times 10^{4}$ Dinobryon $\mathrm{ml}^{-1}$; Fig. 3.12d).

Mixotrophic nanoplankton were numerically important in the upper water column of Wheeler Pond accounting for $\sim 25 \%$ of the total nanoplanktonic algal assemblage (Fig. 3.13d). Absolute abundances of mixotrophic algae were highest in the metalimnion of this pond $\left(\sim 2 \times 10^{4} \mathrm{ml}^{-1}\right)$, and the most important nanoplanktonic mixotroph at this depth was Dinobryon ( $85 \%$ of MNAN), although only $~ 50 \%$ of the Dinobryon populations in both the epilimnion $\left(\sim 1 \times 10^{3} \mathrm{ml}^{-1}\right)$ and metalimnion $\left(>9 \times 10^{3} \mathrm{ml}^{-1}\right)$ were phagotrophically active (Fig. 3.14d). In addition, mixotrophic nanoplankton were moderately important (15-20\% of total PNAN) in the epilimnia of Amphitheater Pond and Little Echo Pond (Fig. $3.13 \mathrm{~g}$, i), but absolute abundances were modest relative to abundances in the metalimnion of Wheeler Pond. Dinobryon and solitary forms of mixotrophic nanoplankton were both present at abundances of $\sim 500 \mathrm{ml}^{-1}$ in the epilimnion of Amphitheater Pond (Fig. 3.14g), while solitary forms dominated the mixotrophic nanoplankton in the epilimnion of Little Echo Pond ( $750 \mathrm{ml}^{-1}$; Fig. 3.14i). Mixotrophic 

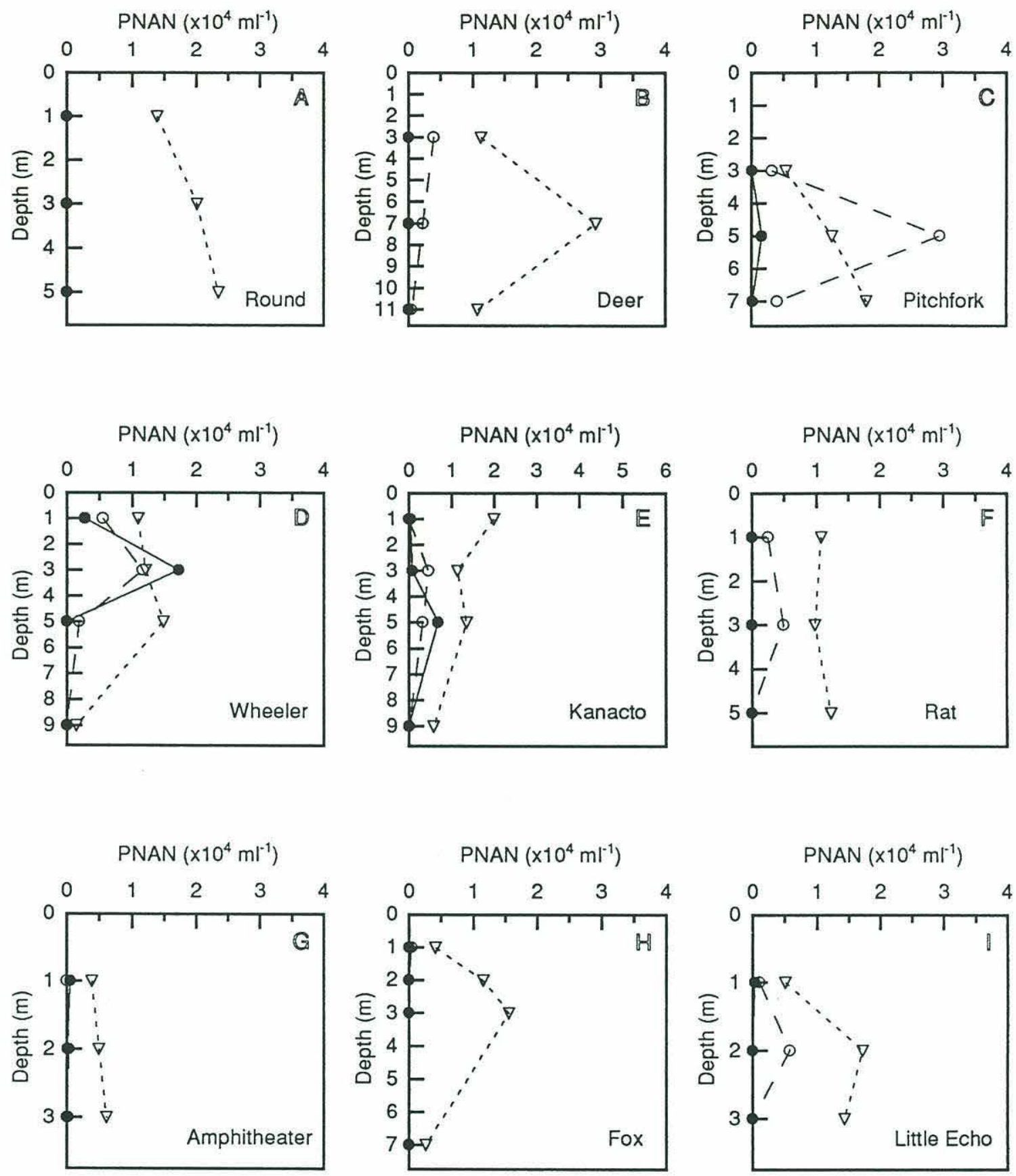

Figure 3.12. Vertical profiles of unidentified solitary phototrophic nanoplankton ( $\nabla$ ), colonial phototrophic nanoplankton ( $\circ$ ) and Dinobryon ( $\bullet$ ) abundances ( $\pm 1 \mathrm{SD}$ ) in low DOC (A-C), mid DOC (D-F) and high DOC (G-I) seepage ponds in the northwest and west central regions of the Adirondack Mountains, NY during July 1992. 

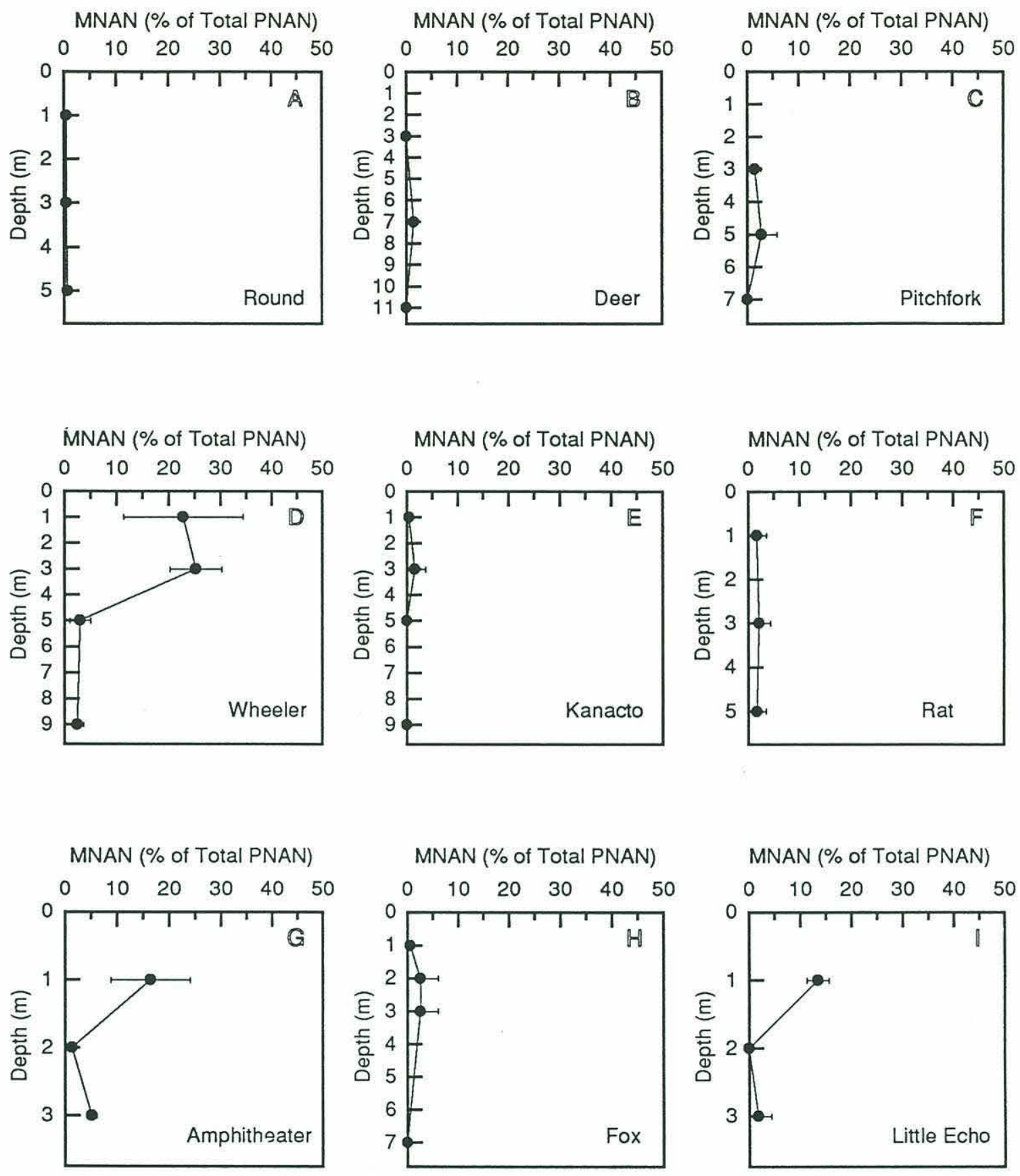

Figure 3.13. Vertical profiles of the percent $( \pm 1 \mathrm{SD})$ of the nanoplanktonic phototroph assemblage that were mixotrophic in low DOC (A-C), mid DOC (D-F) and high DOC (G-I) seepage ponds in the northwest and west central regions of the Adirondack Mountains, NY during July 1992. 

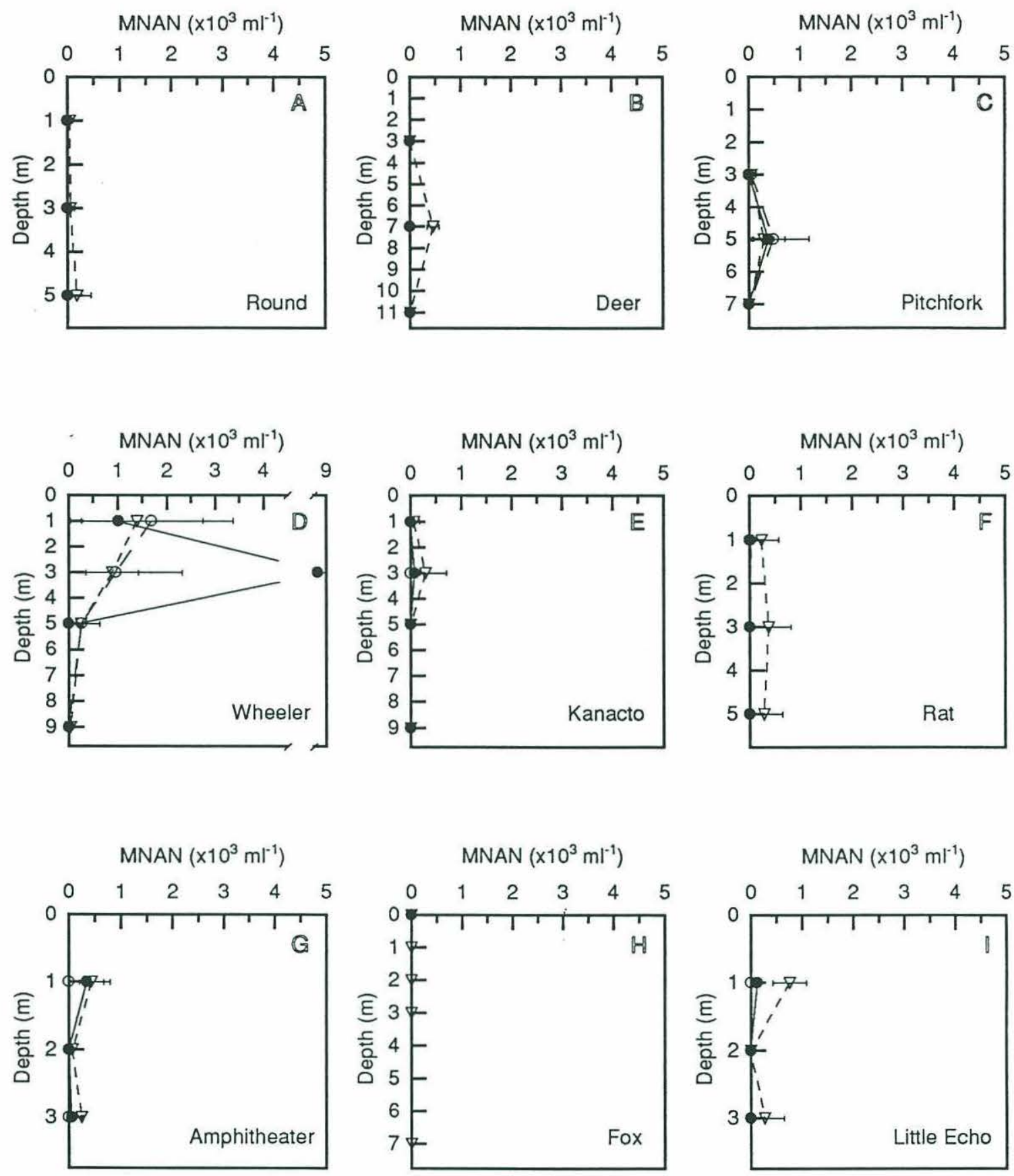

Figure 3.14. Vertical profiles of abundances $( \pm 1 \mathrm{SD})$ of unidentified solitary mixotrophic nanoplankton $(\nabla)$, unidentified colonial mixotrophic nanoplankton $(\circ)$ and phagotrophically active Dinobryon ( - ) in low DOC (A-C), mid DOC (D-F) and high DOC (G-I) seepage ponds in the northwest and west central regions of the Adirondack Mountains, NY during July 1992. 
nanoplankton comprised less than 5\% of the total PNAN assemblages in the remaining ponds (Fig. 3.13a-c, e, f, h).

\section{Coastal Salt Ponds}

The coastal salt ponds examined in this study reside in an outwash plain formed during glacial recession. These small, semi-enclosed coastal lagoons remain connected to the ocean and exhibit small tidal fluctuations. The extent of tidal exchange in the ponds is dependent on the size of the connecting passage to adjacent coastal waters, basin morphology and depth (See Table. 3.1 for surface areas and basin depths) and the degree of freshwater influx. Oyster Pond and Salt Pond have relatively deep main basin depths (4-6 m) compared with the main basin of Perch Pond ( $<3 \mathrm{~m})$. Both Oyster Pond and Salt Pond are also connected directly through narrow culverts to Vineyard Sound, while Perch Pond is indirectly connected to Vineyard Sound by a shallow connection (sill depth $<0.5$ m) to a large embayment that empties into Vineyard Sound. All three ponds have small riverine inputs near the head of the ponds.

\section{Physical characteristics}

Water column stratification differed markedly between the three salt ponds (Fig. 3.15). Perch Pond was fairly well mixed as a result of wind-driven circulation in the shallow basin. A shallow lens $\left(\sim 0.5 \mathrm{~m}\right.$ thick) of slightly cooler $\left(24^{\circ} \mathrm{C}\right)$, less saline water $\left(\sim 17 \%\right.$ o) rested over a relatively well mixed bottom layer of warmer $\left(26.5^{\circ} \mathrm{C}\right), 24 \%$ o water (Fig. 3.15a). The $4 \mathrm{~m}$ basin in Oyster Pond was weakly stratified. The surface layer was well-mixed and was characterized by warm $\left(26.5^{\circ} \mathrm{C}\right)$, brackish $(\sim 7 \%)$ water that extended down to a depth of $2 \mathrm{~m}$. Below this depth, water temperature gradually decreased as salinity increased. Water temperature was $\sim 18^{\circ} \mathrm{C}$ and salinity was 

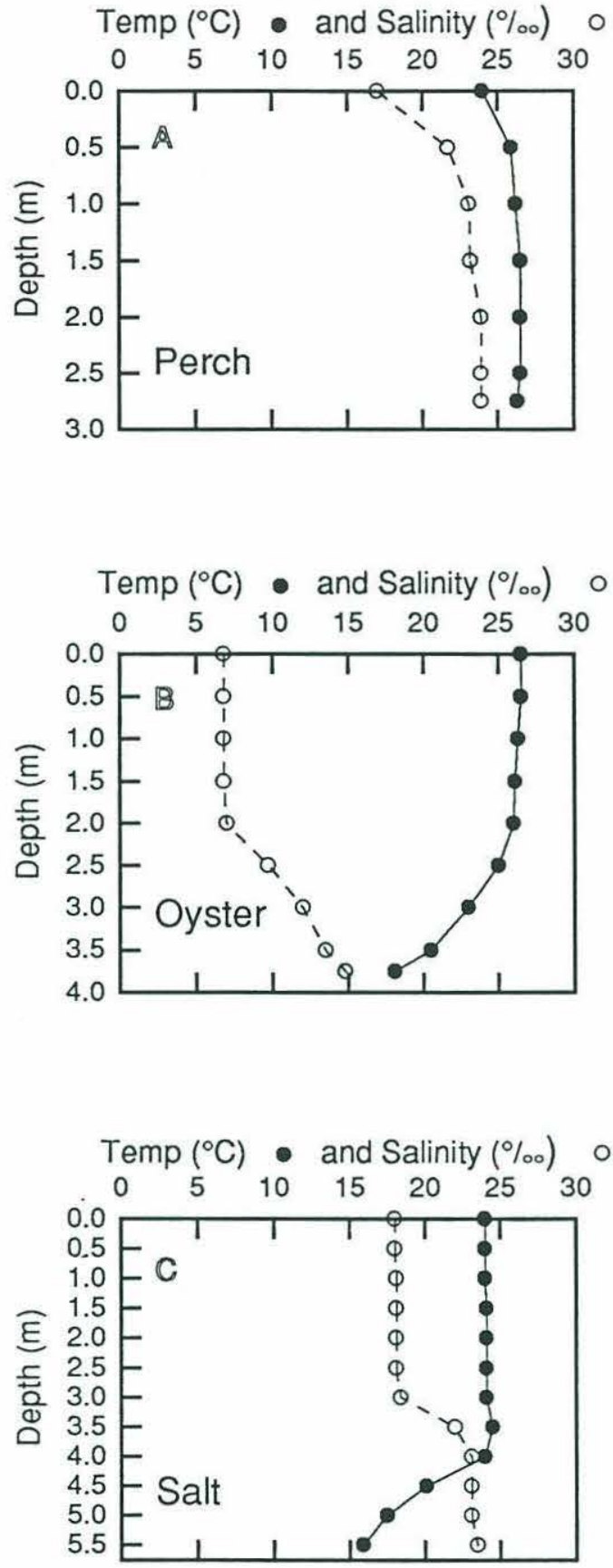

Figure 3.15. Temperature and salinity profiles for Perch Pond (A), Oyster Pond (B) and Salt Pond (C), Falmouth, MA determined during early summer 1993. 
approximately $15 \%$ near the bottom (Fig. 3.15b). Salt Pond was well-stratified at the time of sampling. The surface mixed layer was relatively deep and extended down to 3 m. A sharp halocline was present between 3 and $4 \mathrm{~m}$ where salinity increased from $18 \% \circ$ to nearly $23 \%$. Temperature decreased significantly below $4 \mathrm{~m}$ to $\sim 16^{\circ} \mathrm{C}$ near the bottom (Fig. 3.15c).

Light attenuation rates appeared to be similar in the three coastal ponds (Fig. 3.16), although the availability of light in the bottom layers was less in ponds with deeper basin depths. Greater than $1 \%$ of subsurface light was available throughout the water column in Perch Pond (Fig. 3.16a). One percent of subsurface light was reached near the bottom of Oyster Pond at a depth of $3.5 \mathrm{~m}$ (Fig. 3.16b). The depth of $1 \%$ of subsurface light in Salt Pond was $4 \mathrm{~m}$. This depth coincided with the top of the thermocline in Salt Pond (Fig. 3.16c).

\% oxygen saturation

Oxygen supersaturation was evident in the upper layer of Perch Pond and Oyster Pond (Fig. 3.17a, b). $\mathrm{O}_{2}$ saturation decreased from $\sim 105 \%$ to $\sim 90 \%$ between $0.5 \mathrm{~m}$ and 1 $\mathrm{m}$ in Perch Pond, but the water column remained saturated with oxygen to a depth of $3 \mathrm{~m}$ in Oyster Pond. $\mathrm{O}_{2}$ concentrations in Oyster Pond decreased rapidly from $~ 100 \%$ saturation to $\sim 10 \%$ saturation between $3 \mathrm{~m}$ and $3.5 \mathrm{~m}$. Oxygen concentrations near the surface of Salt Pond were $<95 \%$ saturated and decreased gradually to $\sim 80 \%$ saturation at a depth of $\sim 3 \mathrm{~m}$ (Fig. 3.17c). $\mathrm{O}_{2}$ saturation levels decreased rapidly in the halocline of Salt Pond and became stable at $\sim 10 \%$ saturation in the bottom layer. None of the three ponds exhibited bottom water anoxia. 

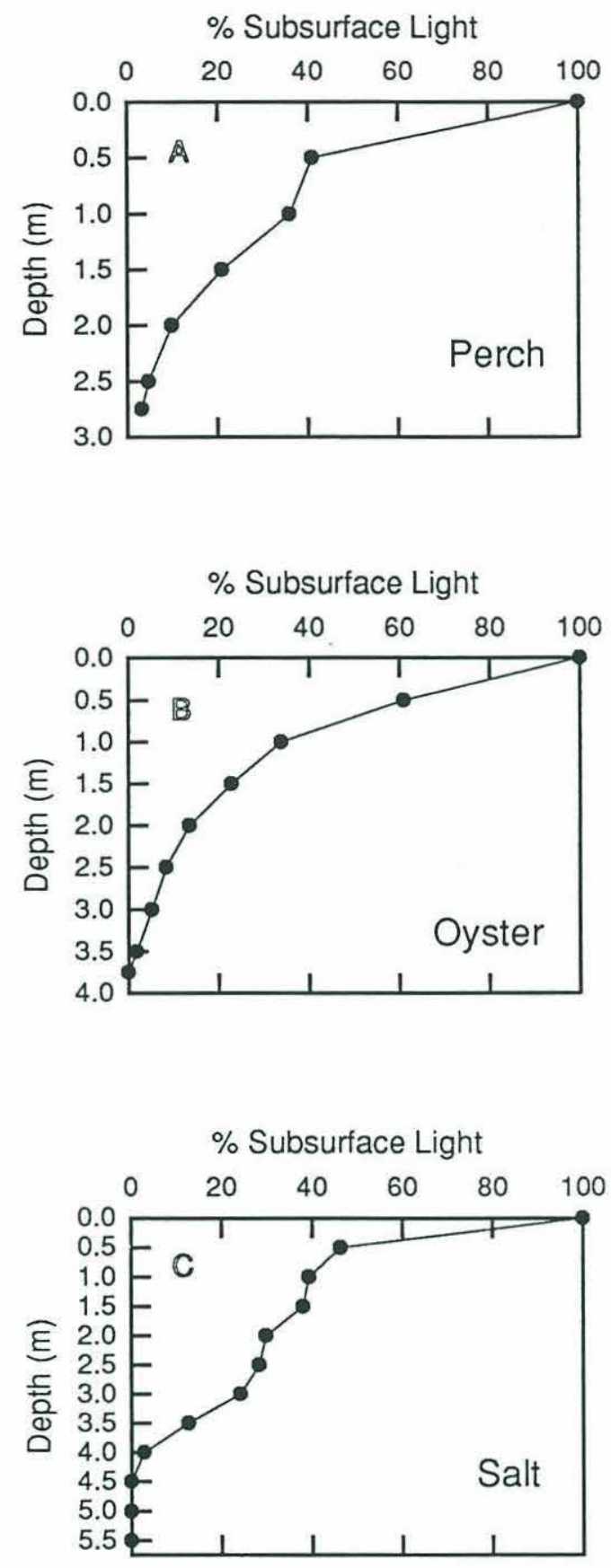

Figure 3.16. Vertical profiles of light iin Perch Pond (A), Oyster Pond (B) and Salt Pond (C), Falmouth, MA determined during early summer 1993. 

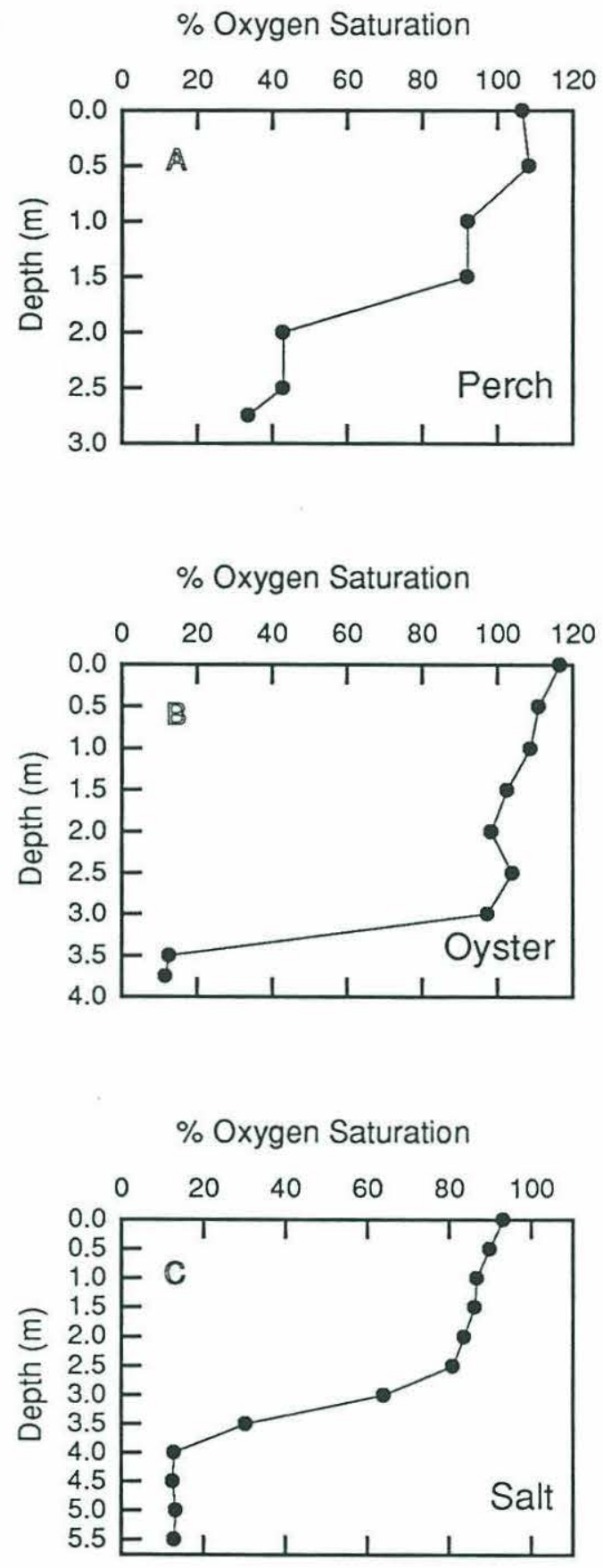

Figure 3.17. Vertical profiles of \% oxygen saturation in Perch Pond (A), Oyster Pond (B) and Salt Pond (C), Falmouth, MA determined during early summer 1993. 


\section{Pigments}

Upper water column chlorophyll $a$ and carotenoid concentrations in Perch Pond were nearly an order of magnitude higher than upper water column concentrations in Salt Pond (Fig. 3.18). Water samples collected for chlorophyll analyses from Oyster Pond were mishandled. Perch Pond chlorophyll $a$ concentrations were $\sim 30 \mu \mathrm{g} \mathrm{L}^{-1}$ in the upper water column (0-1m; Fig. 3.18a). A peak in chlorophyll $a$ concentration $\left(\sim 70 \mu \mathrm{g} \mathrm{L}^{-1}\right)$ was observed at a depth of $2 \mathrm{~m}$. Carotenoid concentrations were lower than chlorophyll $a$ concentrations in Perch Pond, but mirrored chlorophyll $a$ concentrations throughout the water column (Fig. 3.18a). Chlorophyll $a$ and carotenoid concentrations mirrored each other in the upper water column of Salt Pond as well. Their concentrations remained relatively constant to a depth of $3.5 \mathrm{~m}\left(<4 \mu \mathrm{g}\right.$ Chl $a \mathrm{~L}^{-1}, \sim 2 \mu \mathrm{g}$ carotenoid $\left.\mathrm{L}^{-1}\right)$, but below the thermocline both carotenoid and chlorophyll $a$ concentrations increased dramatically, and carotenoid concentrations exceeded chlorophyll $a$ concentrations by more than 4 fold at this depth ( $60 \mu \mathrm{g} \mathrm{Chl} a \mathrm{~L}^{-1},>240 \mu \mathrm{g}$ carotenoid L-1; Fig. 3.18b).

\section{Nutrients}

Ammonium was the dominant form of inorganic nitrogen at each site, except in the surface waters of Perch Pond (Fig. 3.19). Nitrate concentrations ( $\left.8.8 \mu \mathrm{M} \mathrm{NO}_{3}{ }^{-}\right)$ exceeded $\mathrm{NH}_{4}{ }^{+}$concentrations $\left(1.8 \mu \mathrm{M} \mathrm{NH}_{4}{ }^{+}\right)$by nearly five fold in the low salinity lens at the surface of Perch Pond, but $\mathrm{NO}_{3}^{-}$concentrations decreased rapidly in the top meter from $8.8 \mu \mathrm{M}$ to $<1 \mu \mathrm{M} \mathrm{NO}_{3}{ }^{-}$(Fig. 3.19a). $\mathrm{NH}_{4}{ }^{+}$concentrations in Perch Pond remained constant in the top meter and then gradually increased with depth $\left(5 \mu \mathrm{M} \mathrm{NH}_{4}{ }^{+}\right.$at $\left.2.5 \mathrm{~m}\right)$. $\mathrm{NH}_{4}{ }^{+}$concentrations in the upper water columns of Oyster Pond and Perch Pond were also on the order of $2 \mu \mathrm{M} \mathrm{NH}_{4}{ }^{+}$and remained relatively constant with depth down to at least the thermocline. $\mathrm{NH}_{4}+$ concentrations increased dramatically in the thermocline 

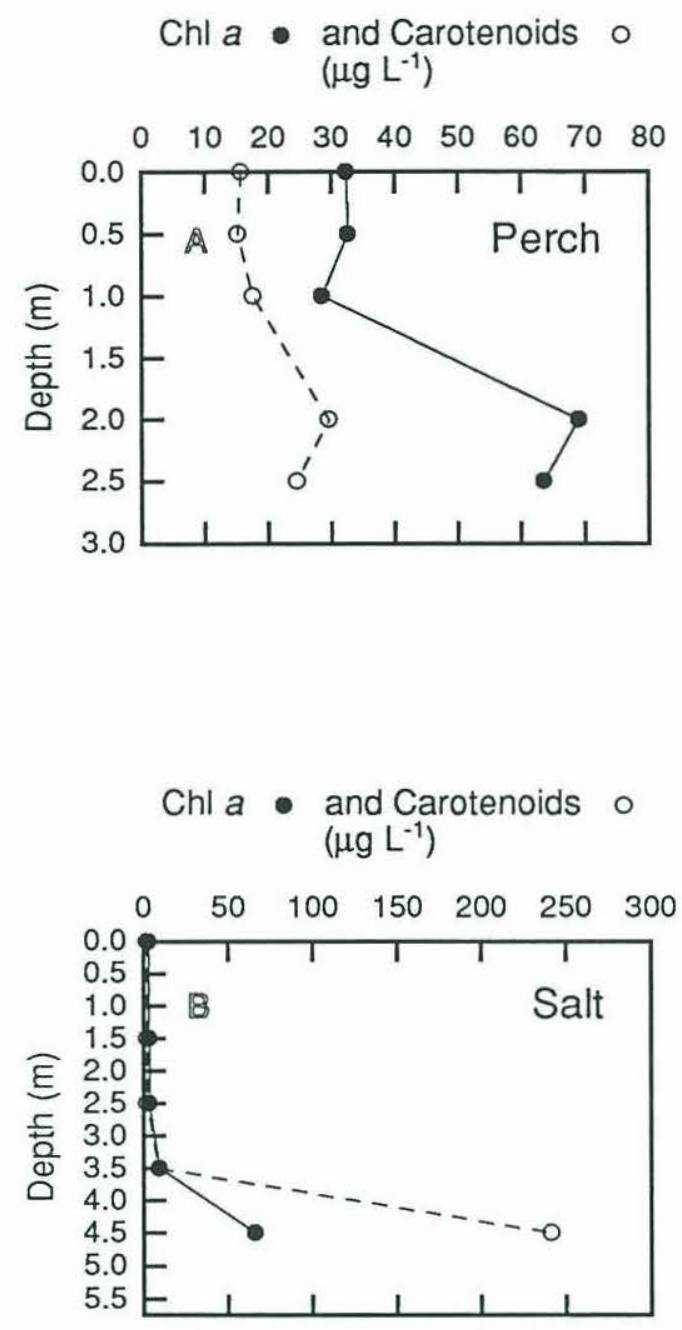

Figure 3.18. Vertical profiles of chlorophyll $a$ and carotenoid concentration in Perch Pond (A) and Salt Pond (B), Falmouth, MA determined during early summer 1993. 

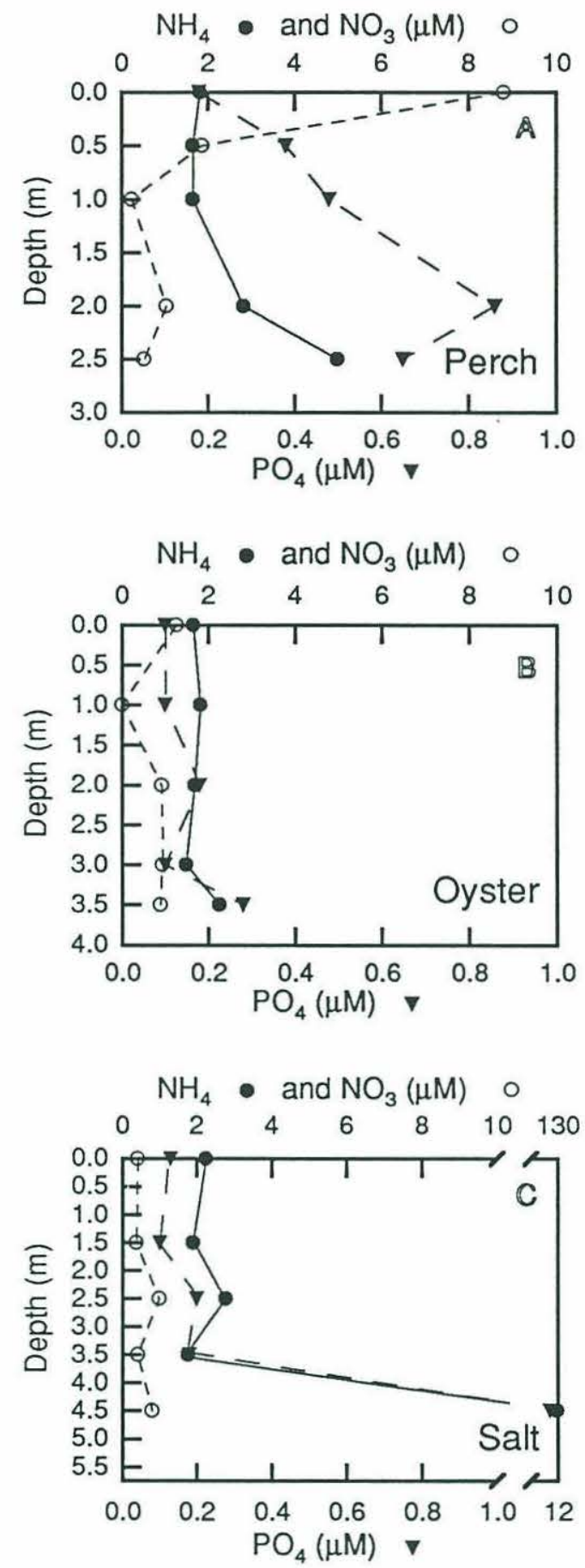

Figure 3.19. Vertical profiles of inorganic nitrogen and phosphorus concentrations in Perch Pond (A), Oyster Pond (B) and Salt Pond (C), Falmouth, MA determined during early summer 1993. 
$\left(130 \mu \mathrm{M} \mathrm{NH}_{4}{ }^{+}\right)$of Salt Pond (Fig. 3.19c), but did not increase significantly $(2.25 \mu \mathrm{M}$ $\mathrm{NH}_{4}{ }^{+}$) in the thermocline of Oyster Pond (Fig. 3.19b). $\mathrm{NO}_{3}^{-}$concentrations in Oyster Pond and Salt Pond did not vary greatly with depth $\left(0.5-1 \mu \mathrm{M} \mathrm{NO}_{3}^{-}\right)$, although there was a $\mathrm{NO}_{3}{ }^{-}$minimum $\left(<0.005 \mu \mathrm{M} \mathrm{NO}_{3}^{-}\right)$observed at $1 \mathrm{~m}$ in Oyster Pond.

Dissolved phosphate tended to mirror $\mathrm{NH}_{4}{ }^{+}$concentrations, particularly in Oyster Pond and Salt Pond. $\mathrm{PO}_{4}{ }^{-3}$ concentrations were generally an order of magnitude lower than $\mathrm{NH}_{4}{ }^{+}$concentrations, and were less than $0.18 \mu \mathrm{M}$ in surface waters of all three coastal ponds during this study. $\mathrm{PO}_{4}^{-3}$ concentrations in Perch Pond increased steadily from the surface down to $2 \mathrm{~m}(0.86 \mu \mathrm{M})$, unlike $\mathrm{NH}_{4}{ }^{+}$concentrations, and then decreased again below this depth $\left(0.65 \mu \mathrm{M} \mathrm{PO}_{4}{ }^{-3}\right.$; Fig. $\left.3.19 \mathrm{a}\right)$. $\mathrm{PO}_{4}^{-3}$ concentrations ranged from 0.10-0.28 $\mu \mathrm{M}$ in Oyster Pond (Fig. 3.20b) and from 0.10-0.20 $\mu \mathrm{M} \mathrm{PO}_{4}{ }^{-3}$ down to the thermocline in Salt Pond. The concentration of $\mathrm{PO}_{4}^{-3}$ below the thermocline in Salt Pond was $11.72 \mu \mathrm{M}$ (Fig. 3.19c).

\section{Microbial population abundances}

Bacterial population abundances were high at all three coastal pond sites ranging from $7 \times 10^{6}$ to $3 \times 10^{7} \mathrm{BACT} \mathrm{ml}^{-1}$. In Perch Pond bacterial abundances in surface waters were approximately $1 \times 10^{7} \mathrm{ml}^{-1}$ and increased with depth $\left(\sim 2.5 \times 10^{7} \mathrm{ml}^{-1}\right.$ at $2.5 \mathrm{~m}$; Fig. 3.20a). Bacterial abundances in Oyster Pond did not vary greatly with depth and ranged from $\sim 7 \times 10^{6}$ to $<1 \times 10^{7} \mathrm{BACT} \mathrm{ml}^{-1}$ (Fig. 3.20d). Bacterial abundances remained relatively constant from the surface to a depth of $3.5 \mathrm{~m}$ in Salt Pond $\left(\sim 1 \times 10^{7} \mathrm{ml}^{-1}\right)$, and then increased dramatically below this depth to nearly $3 \times 10^{7} \mathrm{ml}^{-1}$ (Fig. $3.20 \mathrm{~g}$ ).

Heterotrophic nanoplankton abundances in the low-salinity lens at the surface of Perch Pond were $\sim 1 \times 10^{3} \mathrm{HNAN} \mathrm{ml}^{-1}$ and increased to $\sim 1.3 \times 10^{4} \mathrm{HNAN} \mathrm{ml}^{-1}$ below 0.5 m (Fig. 3.20b). Heterotrophic nanoplankton abundances in Oyster Pond ranged from $\sim 8 \times 10^{3}$ 
Perch

$\operatorname{BACT}\left(\times 10^{7} \mathrm{ml}^{-1}\right) \quad \operatorname{HNAN}\left(\times 10^{3} \mathrm{ml}^{-1}\right)$

PNAN $\left(x 10^{3} \mathrm{ml}^{-1}\right)$
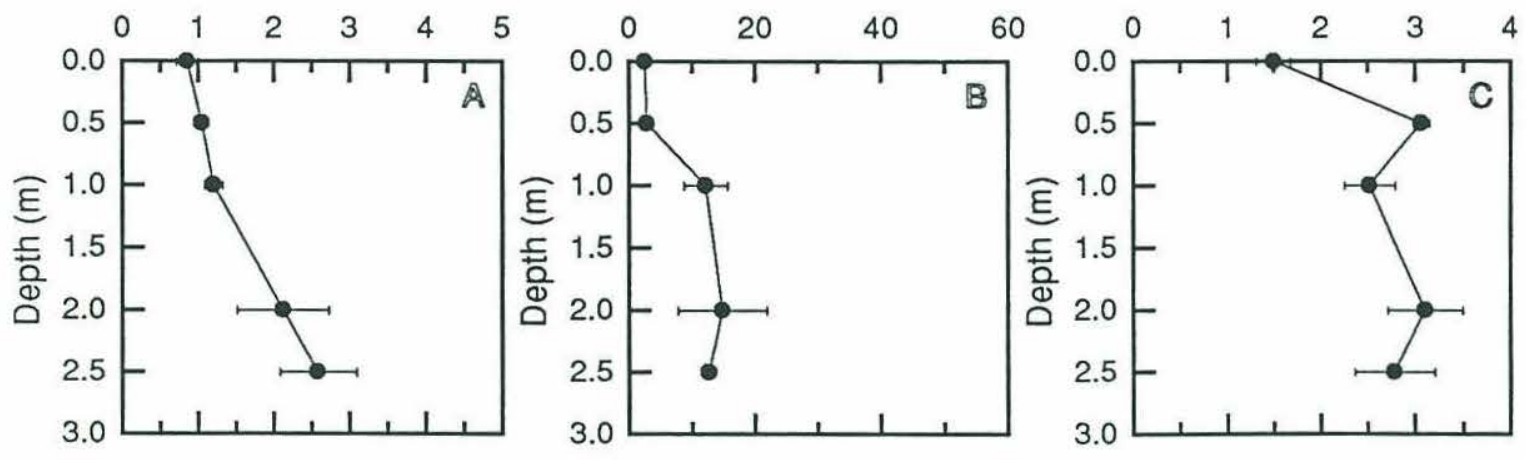

Oyster
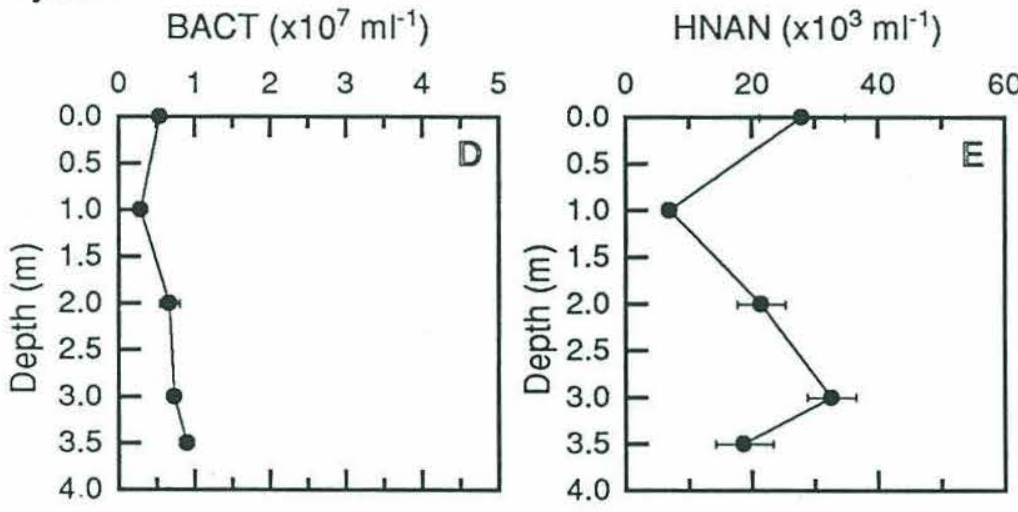

PNAN $\left(\times 10^{3} \mathrm{ml}^{-1}\right)$

\section{Salt}
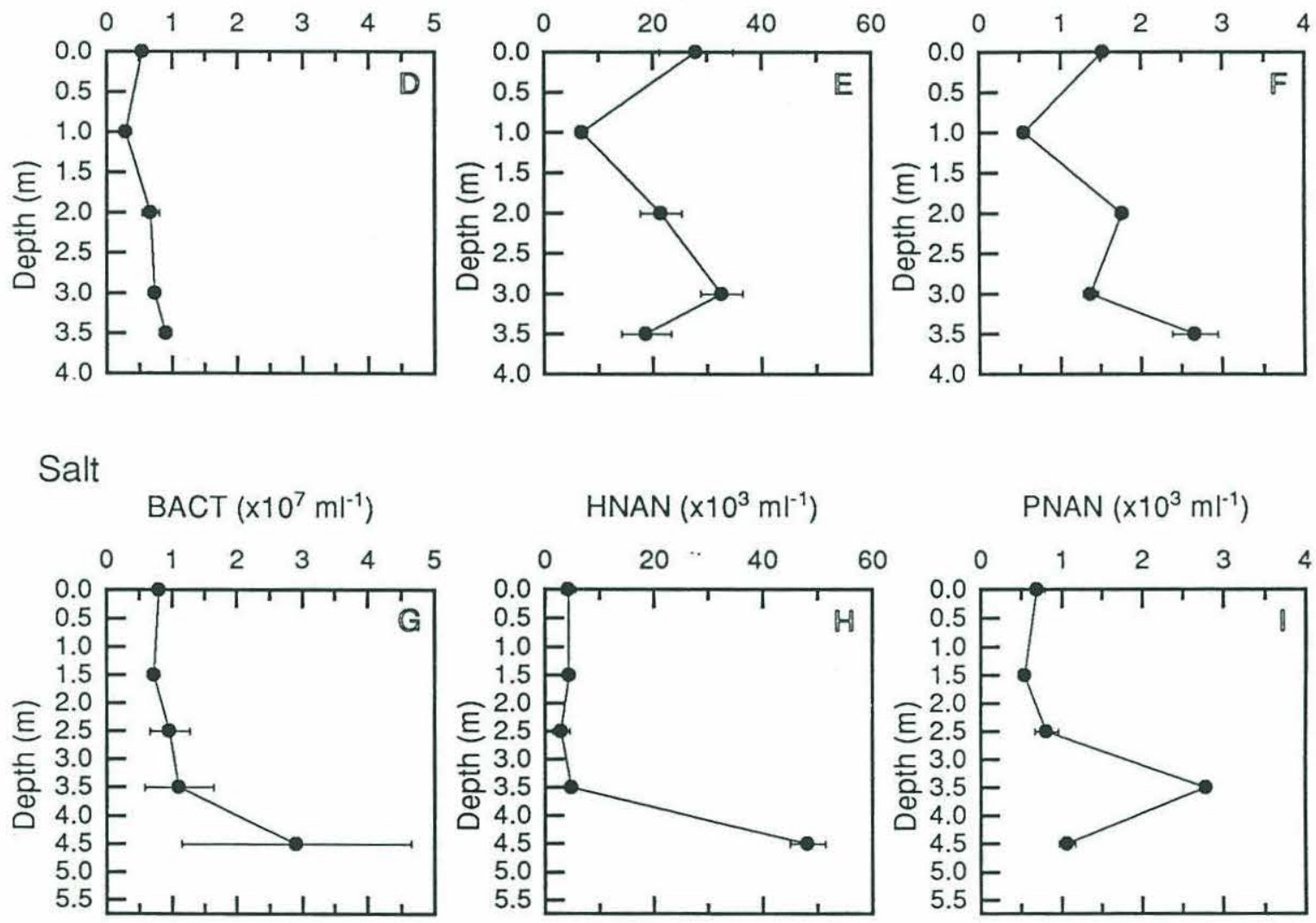

Figure 3.20. Vertical profiles of bacteria (BACT), heterotrophic nanoplankton (HNAN) and phototrophic nanoplankton (PNAN) abundances ( \pm 1 SD) in Perch Pond (A-C), Oyster Pond (D-F) and Salt Pond (G-I) determined during early summer 1993. 
to $3.3 \times 10^{4} \mathrm{HNAN} \mathrm{ml}^{-1}$, but did not show any clear trend with depth (Fig. 3.20e). The depth distribution of heterotrophic nanoplankton in Salt Pond mirrored the depth distribution of bacteria in this pond (Fig. 3.20h). Heterotrophic nanoplankton abundances throughout the upper water column of Salt Pond were relatively constant $\left(\sim 5.2 \times 10^{3}\right.$ HNAN ml-1) and then increased nearly an order of magnitude in the thermocline to almost $5 \times 10^{4} \mathrm{HNAN} \mathrm{ml}^{-1}$ (Fig. 3.20h).

Phototrophic nanoplankton abundances in the three coastal ponds ranged from $\sim 500 \mathrm{ml}^{-1}$ to $>3 \times 10^{3} \mathrm{ml}^{-1}$ (Fig. 3.20c, f, i). Maximum PNAN abundances in Perch Pond occurred $0.5 \mathrm{~m}$ below the surface $\left(\sim 3 \times 10^{3} \mathrm{PNAN} \mathrm{ml}^{-1}\right)$. Below this depth PNAN abundances remained relatively constant (Fig. 3.20c). Phototrophic nanoplankton abundances fluctuated widely with depth in Oyster Pond and abundances ranged from $500 \mathrm{PNAN} \mathrm{ml}^{-1}$ to $2.7 \times 10^{3} \mathrm{PNAN} \mathrm{ml}^{-1}$ (Fig. 3.20f). PNAN abundances were relatively constant $\left(<1 \times 10^{3} \mathrm{ml}^{-1}\right)$ from surface waters down to the top of the halocline $(\sim 3 \mathrm{~m})$ in Salt Pond (Fig. 3.20i). A peak in the abundance of phototrophic nanoplankton $\left(3 \times 10^{4} \mathrm{ml}^{-1}\right)$ was observed near the middle of the halocline $(3.5 \mathrm{~m})$ in Salt Pond, and below this depth phototrophic nanoplankton abundances decreased to $\sim 1 \times 10^{3} \mathrm{PNAN} \mathrm{ml}^{-1}$.

The absolute and relative abundances of mixotrophic nanoplankton were low in all three coastal ponds (Fig. 3.21). Subsurface peaks in phototrophic nanoplankton abundance did not correlate with peaks in mixotrophic nanoplankton abundance in any of the ponds. The highest abundances of mixotrophic nanoplankton were observed in surface waters of Oyster Pond ( 142 ml-1, 2\% of total PNAN; Fig. 3.21b). Mixotrophic nanoplankton abundances in Perch Pond were highest at a depth of $1 \mathrm{~m}\left(\sim 100 \mathrm{ml}^{-1}\right)$, but comprised only $1.1 \%$ of the total PNAN assemblage (Fig. 3.21a). Mixotrophic nanoplankton were present in Salt Pond at less than 15 cells $\mathrm{ml}^{-1}$ and contributed less than $0.4 \%$ to the phototroph assemblage (Fig. 3.21c).

Microplankton were also enumerated in Salt Pond after significant numbers of mixotrophic ciliates (chloroplast-retaining ciliates) were observed. Ciliates dominated 

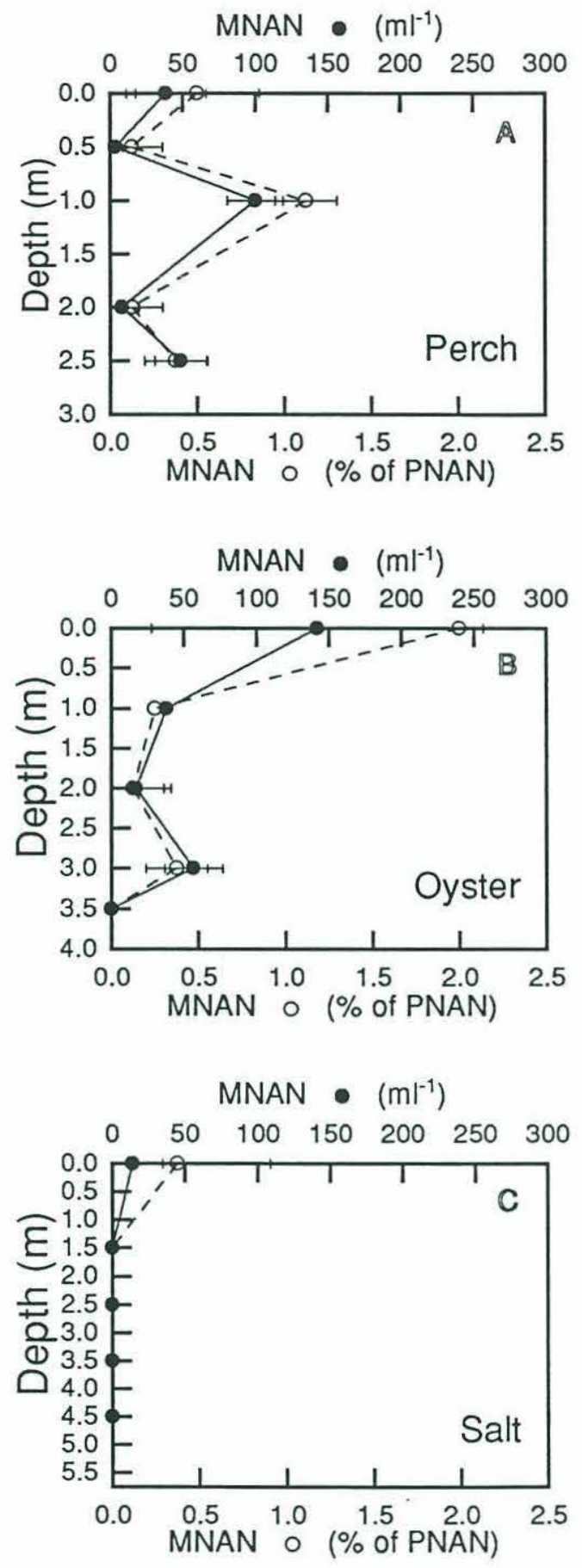

Figure 3.21. Vertical profiles of mixotrophic nanoplankton absolute ( $\bullet$ ) and relative ( $\circ$ ) abundance in Perch Pond (A), Oyster Pond (B) and Salt Pond (C), Falmouth, MA determined during early summer 1993. 
the microplankton assemblage throughout the upper water column, and their total abundances (heterotrophic and mixotrophic ciliates) were highest near the middle of the halocline ( $3.5 \mathrm{~m} ;>5 \times 10^{5} \mathrm{~L}^{-1}$; Fig. 3.22). Other microplankton present at the time of sampling included ebridians and dinoflagellates (data not shown). Ebridians were only observed at a depth of $3.5 \mathrm{~m}$ and did not exceed $1.2 \times 10^{3} \mathrm{~L}^{-1}$. Dinoflagellates were present at all depths, but were only numerically important in the halocline with abundances of $\sim 2 \times 10^{5}$ $\mathrm{L}^{-1}$. "Green" ciliates were observed throughout the upper water column of Salt Pond (Fig. 3.22). Absolute abundances of these chloroplast-retaining ciliates were highest at a depth of $3.5 \mathrm{~m}\left(1.4 \times 10^{5} \mathrm{~L}^{-1}\right)$, although the relative abundance of green ciliates was highest at the surface (39\% of total ciliate abundance) and decreased with depth ( $<27 \%$ at $3.5 \mathrm{~m})$. 


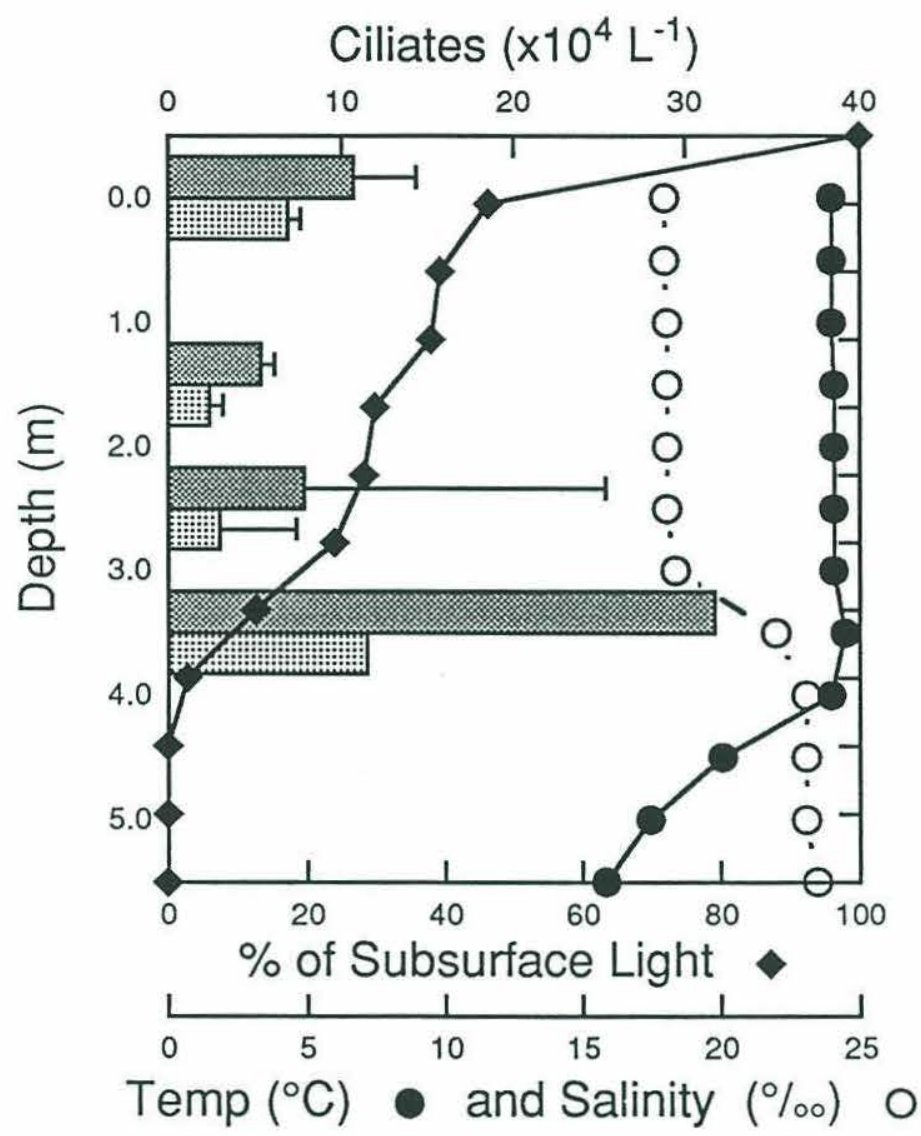

Figure 3.22. Vertical distribution and abundance ( \pm 1 SD) of heterotrophic ciliates ( ) and mixotrophic ciliates ( 曲曲 ), and vertical profiles of temperature ( $\bigcirc$ ), salinity ( $\mathrm{O}$ ) and light attenuation ( $\diamond$ ) in Salt Pond, Falmouth, MA on 17 July 1993. 


\section{DISCUSSION}

Mixotrophic algae in Adirondack seepage ponds

Mixotrophic algae were a numerically important and abundant component of the total nanoplanktonic algal assemblage in only one pond examined during the seepage pond survey. Mixotrophic algae accounted for approximately $25 \%$ of the nanoplanktonic algal assemblage in the epilimnion and metalimnion of Wheeler Pond. Total abundances of mixotrophic algae were high in the metalimnion, and a large population of the mixotrophic chrysophyte Dinobryon was present at this depth $\left(1.7 \times 10^{4} \mathrm{ml}^{-1}\right)$. Dinobryon was less important in the epilimnion, and $~ 50 \%$ of these two upper water column populations of Dinobryon were phagotrophically active at the time of this study. Wheeler Pond was of moderate DOC concentration relative to the ponds surveyed. Mixotrophic algae in the upper water columns of two ponds of high DOC concentration (Amphitheater and Little Echo) were moderately important (15\%), but absolute abundances were more than an order of magnitude lower $\left(\sim 1 \times 10^{3} \mathrm{ml}^{-1}\right)$ than MNAN abundances in Wheeler Pond. The dominant forms of mixotrophic algae in the epilimnia of Amphitheater Pond and Little Echo Pond were unidentified solitary forms, unlike Wheeler Pond in which Dinobryon dominated the mixotroph assemblage. Mixotrophic nanoplankton abundances in the remaining seven ponds that were surveyed were very modest $(<3 \%$ of the total nanoplanktonic algal assemblage), and the dominant forms of mixotrophic algae varied.

If it is assumed that only $50 \%$ of the mixotroph populations in these other ponds were phagotrophically active, similar to the Dinobryon population in Wheeler Pond, the abundance of mixotrophic nanoplankton in these other ponds would still be modest.

One hypothesis for explaining mixotroph abundances in these ponds was predicated on the belief that some mixotrophic algae consume bacteria in order to obtain major nutrients $(\mathrm{N}, \mathrm{P})$. Ponds constituting a gradient in DOC concentration were 
examined based on the assumption that DOC might stimulate bacterial production (Tranvik, 1988), and if the C:N:P ratio of the carbon substrate was high, increased bacterial production along the DOC gradient would increase competition for dissolved inorganic nutrients between bacteria and algae. The relative and/or absolute abundances of mixotrophic algae were therefore hypothesized to increase with increasing DOC concentration because mixotrophic algae may gain a selective advantage over other algae under conditions of increased nutrient stress by consuming bacteria directly.

While the ability to look for correlations in the data was constrained by the limited number of ponds and depths within ponds that could be sampled during the study period, clearly no relationship existed between the relative or absolute abundance of mixotrophic nanoplankton and pond DOC concentration. One reason may be that competition for nutrients between bacteria and phytoplankton did not increase along the DOC gradient, and therefore a selective advantage for mixotrophic algae may not have existed in high DOC ponds relative to low DOC ponds. It may have been that dissolved organic carbon compounds in these ponds were relatively inert and did not serve as substrate for bacterial production. Alternatively, DOC in the ponds may have been susceptible to bacterial degradation, but the carbon:nutrient ratio of the organic substrates may have been low. Bacterial uptake of dissolved inorganic nutrients therefore would not have been expected to increase with increasing DOC concentration. Dissolved inorganic nutrient concentrations in this study of nine ponds were, in fact, positively correlated with DOC concentration. This positive correlation is contrary to the hypothesis above. Thus, the carbon:nutrient ratio of the DOC and/or the relative stability of the DOC in these small forested ponds may have contributed to the lack of any clear relationship between mixotroph abundance and DOC concentration. 


\section{Dinobryon in Wheeler Pond}

The mixotrophic chrysophyte Dinobryon was found to be numerically important in the upper water column of Wheeler Pond, and a peak in the abundance of Dinobryon occurred near the mid-metalimnion. It has been shown in laboratory experiments with individual species of mixotrophic algae, that these algae may benefit from phagotrophy in a number of different ways, including the acquisition of carbon, major nutrients or essential growth factors. Investigators have observed metalimnetic peaks of Dinobryon in several lakes and have suggested that phagotrophic activity was important in sustaining these populations at the low light levels experienced at these depths (Bird \& Kalff, 1986; Bird \& Kalff, 1987; Bird \& Kalff, 1989). In laboratory studies with D. cylindricum, Caron et al. (1992) found that phagotrophic activity persisted in populations of $D$. cylindricum under low light conditions or short photoperiod. No net bacterial carbon incorporation occurred under these conditions, although population densities of $D$. cylindricum were maintained. Based on these results, Caron et al. (1992) suggested that phagotrophy may be an important carbon source for maintenance metabolism in suboptimal light regimes and may allow for the survival of this alga under these conditions. Light levels in the mid-metalimnion of Wheeler Pond at the time of this study were approximately $3 \%$ of subsurface light. The depth distribution of Dinobryon in this study and the large proportion of these cells that were phagotrophically active are therefore consistent with findings from other field and laboratory studies.

Interestingly though, phagotrophic activity by the Dinobryon population in the epilimnion was observed to be at a similar level $(\sim 50 \%)$ as in the metalimnetic population. It has been suggested that bacterivory is necessary for the growth of Dinobryon even in optimal light regimes, although phagotrophy may also allow for the survival of this alga in low light (Caron et al., 1992). In experiments with $D$. cylindricum conducted in a variety of light regimes, it was found that this alga could not be 
maintained axenically in optimal light, and that $D$. cylindricum also could not survive in continuous darkness when provided with high concentrations of bacteria (Caron et al., 1992). It was therefore hypothesized that this alga is an obligate photophagotroph, and that the primary function of phagotrophy may be to provide Dinobryon with major nutrients ( $\mathrm{N}$ or $\mathrm{P}$ ) or an essential organic compound(s) required for phototrophic growth (Caron et al., 1992). Phosphate acquisition was suggested by Veen (1991) as the most likely advantage of bacterivory for Dinobryon, since Dinobryon generally occurs in oligotrophic environments (Sandgren, 1988) and bacteria are typically enriched in P (Vadstein et al., 1988). Dissolved inorganic phosphate concentrations were less than 0.25 $\mu \mathrm{M} \mathrm{PO}_{4}{ }^{-3}$ in the epilimnia and metalimnia of Wheeler Pond during this study, and this $\mathrm{PO}_{4}{ }^{-3}$ concentration has been shown to limit the growth of two species of Dinobryon in culture experiments (Lehman, 1976). Although the phagotrophic activity of Dinobryon in Wheeler Pond is consistent with the hypothesis that this behavior is important as a source of $\mathrm{P}$ for this alga, the results are not conclusive, and the possibility remains that the primary function of phagotrophy in Dinobryon may be to provide specific growth factors required for phototrophic growth.

\section{Mixotrophy in coastal salt ponds}

This is the first investigation of the occurrence of mixotrophic algae in small coastal lagoons. The abundances of mixotrophic algae in the nanoplankton size range were low $\left(<150 \mathrm{ml}^{-1}\right)$ and they were numerically unimportant $(<2 \%$ of total nanoplanktonic algal abundances) throughout the water column in all three coastal salt ponds at the time of the study. Even if only $50 \%$ of the mixotrophic algae present were phagotrophically active and absolute abundances of mixotrophic nanoplankton were doubled, mixotrophic algae would still have comprised an insignificant fraction of the total nanoplanktonic algal assemblage in these ponds. Therefore, even though the sample 
size was small (only three sites examined), the consistently low abundances observed during this study suggest that mixotrophic nanoplankton may not be common in semienclosed coastal lagoons, at least during summer. This is in contrast to other coastal (Dahl et al., 1989; Johnsen \& Lein, 1989; Børsheim et al., 1990), open ocean (see Chapter 2) and freshwater environments (Bird \& Kalff, 1986; Kimura et al., 1986; Porter, 1988; Sanders \& Porter, 1988; Bird \& Kalff, 1989; Bennett et al., 1990; Sanders, 1991; Berninger et al., 1992), where mixotrophic algae can be a highly significant component of the nanoplankton assemblage. These small coastal lagoons are typified by the aperiodic formation and breakdown of sharp salinity gradients, however, due to their relatively shallow bathymetry and wind-driven circulation. In contrast to species inhabiting freshwater or the open ocean and other coastal waters, species inhabiting these semi-enclosed coastal ponds must be tolerant of changing salinity (euryhaline). An inability of species of mixotrophic nanoplankton to tolerate shifts in salinity would therefore account for their relative unimportance in these coastal salt ponds.

While mixotrophic nanoplankton were not common in these coastal ponds at the time of study, mixotrophic ciliates (chloroplast-retaining ciliates capable of photosynthesis and phagotrophy) were found to be an abundant component of the microplankton $(20-200 \mu \mathrm{m})$ assemblage in one of the ponds. Several different species of "green" ciliates (chloroplast-retaining ciliates) were present at relatively high abundances throughout the upper water column of Salt Pond. Chloroplast-retaining ciliates appear to be common in estuarine, coastal and offshore areas (Blackbourn et al., 1973; Beers et al., 1980; Laval-Peuto \& Febvre, 1986; Stoecker et al., 1987; Stoecker et al., 1989). During a previous study in adjacent nearshore waters conducted by Stoecker et al. (1987), mixotrophic ciliates were found to be a numerically important ( $42 \%$ of total ciliates) component of the total microplanktonic ciliate assemblage in surface waters in spring and summer. During this study, "green" ciliates also comprised a large fraction (39\%) of the microplanktonic ciliate assemblage in surface waters. Interestingly though, abundances 
of mixotrophic ciliates throughout the water column in Salt Pond were higher and exceeded abundances previously observed in surface waters of the adjacent nearshore areas (Stoecker et al., 1987). The impact of larger grazers of microplanktonic ciliates was not examined and may have been important in the development of high abundances of mixotrophic ciliates at this site.

The relative importance of mixotrophic ciliates decreased with depth in Salt Pond as the abundance of heterotrophic ciliates increased. Absolute abundances of both mixotrophic $\left(\sim 1.4 \times 10^{5} \mathrm{~L}^{-1}\right)$ and heterotrophic ciliates $\left(>3.6 \times 10^{5} \mathrm{~L}^{-1}\right)$ were greatest at a depth of $3.5 \mathrm{~m}$ which coincided with the mid-halocline. The halocline was reinforced by a rapid decrease in temperature suggesting that a very strong pycnocline existed in the region of the ciliate maximum. High abundances of total ciliates observed at a depth of $3.5 \mathrm{~m}$ in Salt Pond therefore may have been a consequence of the unique physical feature present at this depth.

Although mixotrophic ciliates were documented in Salt Pond at high abundances, they were not observed in the other two coastal ponds examined in this study. Other microplanktonic mixotrophs were, however, observed in one of the other ponds at low concentrations. One or two microplanktonic dinoflagellates containing chlorophyll and ingested fluorescent tracers were observed in two samples from Perch Pond. Recently, mixotrophic dinoflagellates that were feeding primarily on nanociliates were also documented in regions of the Chesapeake Bay estuary (Bockstahler \& Coats, 1993a; Bockstahler \& Coats, 1993b). It appears that while mixotrophy may not be prevalent among the nanoplankton assemblage in these small coastal lagoons during summer, this trophic behavior may be important for some microplanktonic species in these environments. The influence of mixotrophy in the transfer of energy and nutrients in estuarine microbial food webs may therefore differ markedly from that in freshwater and open ocean plankton communities where nanoplanktonic mixotrophs can be more common. 


\section{REFERENCES}

Andersson, A., Falk, S., Samuelsson, G. \& Hagström, A. 1989 Nutritional characteristics of a mixotrophic nanoflagellate, Ochromonas sp. Microbial Ecology 17, $117-128$

Azam, F., Fenchel, T., Field, J. G., Gray, J. S., Meyer-Reil, L. A. \& Thingstad, F. 1983 The ecological role of water-column microbes in the sea. Marine Ecology Progress Series 10, 257-263

Beers, J. R., Reid, F. M. H. \& Stewart, G. L. 1980 Microplankton population structure in Southern California nearshore waters in late spring. Marine Biology 60, 209-226

Beers, J. R., Reid, F. M. H. \& Stewart, G. L. 1982 Seasonal abundance of the microplankton population in the North Pacific central gyre. Deep-Sea Research 29, 227-245

Bendschneider, K. \& Robinson, R. 1952 A new spectrophotometric method for the determination of nitrite in sea water. Journal of Marine Research 11, 87-96

Bennett, S. J., Sanders, R. W. \& Porter, K. G. 1990 Heterotrophic, autotrophic and mixotrophic nanoflagellates: seasonal abundances and bacterivory in a eutrophic lake. Limnology and Oceanography 35, 1821-1832

Berninger, U.-G., Caron, D. A. \& Sanders, R. W. 1992 Mixotrophic algae in three icecovered lakes of the Pocono Mountains, U.S.A. Freshwater Biology 28, 263-272

Bird, D. F. \& Kalff, J. 1986 Bacterial grazing by planktonic lake algae. Science 231, 493-495

Bird, D. F. \& Kalff, J. 1987 Algal phagotrophy: Regulating factors and importance relative to photosynthesis in Dinobryon (Chrysophyceae). Limnology and

Oceanography 32, 277-284

Bird, D. F. \& Kalff, J. 1989 Phagotrophic sustenance of a metalimnetic phytoplankton peak. Limnology and Oceanography 34, 155-162

Blackbourn, D. J., Taylor, F. J. R. \& Blackbourn, J. 1973 Foreign organelle retention by ciliates. Journal of Protozoology 20, 286-288

Bockstahler, K. R. \& Coats, D. W. 1993a Grazing of the mixotrophic dinoflagellate Gymnodinium sanguineum on ciliate populations of Chesapeake Bay. Marine Biology 116, 477-487

Bockstahler, K. R. \& Coats, D. W. 1993b Spatial and temporal aspects of mixotrophy in Chesapeake Bay dinoflagellates. Journal of Eukaryotic Microbiology 40, 49-60

Børsheim, K. Y., Bratbak, G. \& Heldal, M. 1990 Enumeration and biomass estimation of planktonic bacteria and viruses by transmission electron microscopy. Applied and Environmental Microbiology 56, 352-356 
Bukaveckas, P. A. 1993 Changes in primary productivity associated with liming and reacidification of an Adirondack lake. Environmental Pollution 79, 127-133

Caron, D. A. 1983 Technique for enumeration of heterotrophic and phototrophic nanoplankton, using epifluorescence microscopy, and comparison with other procedures. Applied and Environmental Microbiology 46, 491-498

Caron, D. A., Sanders, R. W., Lim, E. L., Marrasé, C., Amaral, L. A., Whitney, S., Aoki, R. B. \& Porter, K. G. 1992 Light-dependent phagotrophy in the freshwater mixotrophic chrysophyte Dinobryon cylindricum. Microbial Ecology 25, 93-111

Dahl, D., Lindahl, O., Paasche, E. \& Throndsen, J. 1989 The Chrysochromulina polylepis bloom in Scandinavian waters during Spring, 1988. In Novel Phytoplankton Blooms: causes and impacts of recurrent brown tides and other unusual blooms (Cosper, E. M., Bricelj, V. M. \& Carpenter, E. J., eds.). Springer-Verlag, Berlin. pp. 383-405.

Durbin, E. G., Krawiec, R. W. \& Smayda, T. J. 1975 Seasonal studies on the relative importance of different size fractions of phytoplankton in Narragansett Bay (USA). Marine Biology 32, 271-287

Estep, K. W., Davis, P. G., Hargraves, P. E. \& Sieburth, J. M. 1984 Chloroplast containing microflagellates in natural populations of North Atlantic nanoplankton, their identification and distribution; including a description of five new species of Chrysochromulina (Prymnesiophyceae). Protistologia 20, 613-634

Fenchel, T. 1982a Ecology of heterotrophic microflagellates. III. Adaptations to heterogeneous environments. Marine Ecology Progress Series 9, 25-33

Fenchel, T. 1982b Ecology of heterotrophic microflagellates. IV. Quantitative occurrence and importance as bacterial consumers. Marine Ecology Progress Series 9, $35-42$

Hallegraeff, G. M. 1981 Seasonal study of phytoplankton pigments and species at a coastal station off Sydney: importance of diatoms and the nanoplankton. Marine Biology 61, 107-118

Ilmavirta, V. 1983 The role of flagellated phytoplankton in chains of small brownwater lakes in southern Finland. Ann. Bot. Fennici 20, 187-195

Jeffrey, S. W. \& Humphrey, G. F. 1975 New spectrophotometric equations for determining chlorophylls $a, b, c_{1}$ and $c_{2}$ in higher plants, algae and natural phytoplankton. Biochemie und Physiologie der Pflanzen 167, 191-194

Johnsen, T. M. \& Lein, T. E. 1989 Prymnesium parvum Carter, (Prymnesiophyceae) in association with macroalgae in Ryfylke, southwestern Norway. Sarsia 74, 277-281

Kimura, B. \& Ishida, Y. 1986 Possible phagotrophic feeding of bacteria in a freshwater red tide Chrysophyceae Uroglena americana. Bulletin of the Japanese Society of Scientific Fisheries 52, 697-701

Kimura, B. \& Ishida, Y. 1989 Phospholipid as a growth factor of Uroglena americana, a red tide Chrysophyceae in Lake Biwa. Nippon Suisan Gakkaishi 55, 799-804 
Kimura, B., Ishida, Y. \& Kadota, H. 1986 Effect of naturally collected bacteria on growth of Uroglena americana, a freshwater red tide Chrysophyceae. Bulletin of the Japanese Society of Scientific Fisheries 52, 691-696

Laval-Peuto, M. \& Febvre, M. 1986 On plastid symbiosis in Tontonia appendiculariformis (Ciliophora, Oligotrichina). BioSystems 19, 137-158

Lehman, J. T. 1976 Ecological and nutritional studies on Dinobryon Ehrenb: seasonal periodicity and the phosphate toxicity problem. Limnology and Oceanography 21, 646658

Likens, G. E. 1975 Primary productivity of inland aquatic ecosystems. In Primary productivity of the biosphere (Lieth, H. \& Whittaker, R. H., eds.). Springer-Verlag, New York. pp.

Murphy, J. \& Riley, J. P. 1962 Determination of phosphate in natural waters. Anal. Chem. Acta 27, 31-36

Nygaard, K. \& Tobiesen, A. 1993 Bacterivory in algae: A survival strategy during nutrient limitation. Limnology and Oceanography 38, 273-279

Parsons, T. R., Maita, Y. \& Lalli, C. M. 1984 A manual of chemical and biological methods for seawater analysis. Pergamon Press, Oxford.

Pomeroy, L. R. 1974 The ocean's food web, a changing paradigm. Bioscience 24, 499-504

Porter, K. G. 1988 Phagotrophic phytoflagellates in microbial food webs.

Hydrobiologia 159, 89-97

Porter, K. G. \& Feig, Y. S. 1980 The use of DAPI for identifying and counting aquatic microflora. Limnology and Oceanography 25, 943-948

Salonen, K. \& Jokinen, S. 1988 Flagellate grazing on bacteria in a small dystrophic lake. Hydrobiologia 161, 203-209

Sanders, R. W. 1991 Mixotrophic protists in marine and freshwater ecosystems. Journal of Protozoology 38, 76-81

Sanders, R. W. \& Porter, K. G. 1988 Phagotrophic phytoflagellates. Advances in Microbial Ecology 10, 167-192

Sanders, R. W., Porter, K. G., Bennett, S. J. \& DeBiase, A. E. 1989 Seasonal patterns of bacterivory by flagellates, ciliates, rotifers, and cladocerans in a freshwater planktonic community. Limnology and Oceanography 34, 673-687

Sanders, R. W., Porter, K. G. \& Caron, D. A. 1990 Relationship between phototrophy and phagotrophy in the mixotrophic chrysophyte Poterioochromonas malhamensis.

Microbial Ecology 19, 97-109

Sandgren, C. D. 1988 The ecology of Chrysophyte flagellates: Their growth and perennation strategies as freshwater phytoplankton. In Growth and reproduction strategies of freshwater phytoplankton (Sandgren, C. D., eds.). Cambridge University Press, Cambridge. pp. 9-104. 
Saunders, P. A. 1992 Phytoplankton production and limnological characteristics of twelve Adirondack seepage lakes. Master of Arts thesis, Indiana University, Department of Biology.

Scheiner, D. 1976 Determination of ammonia and Kjeldahl nitrogen by indophenol method. Water Research 10,31-36

Sherr, B. \& Sherr, E. 1983 Enumeration of heterotrophic microprotozoa by epifluorescence microscopy. Estuarine and Coastal Shelf Science 16, 1-17

Sherr, B. F., Sherr, E. B. \& Berman, T. 1983 Grazing, growth, and ammonium excretion rates of a heterotrophic microflagellate fed with four species of bacteria. Applied and Environmental Microbiology 45, 1196-1201

Sherr, B. F., Sherr, E. B. \& Fallon, R. D. 1987 Use of monodispersed, fluorescently labeled bacteria to estimate in situ protozoan bacterivory. Applied and Environmental Microbiology 53, 958-965

Sherr, E. B., Caron, D. A. \& Sherr, B. F. 1993 Staining of heterotrophic protists for visualization via epifluorescence microscopy. In Current Methods in Aquatic Microbial Ecology (Kemp, P., Cole, J., Sherr, B. \& Sherr, E., eds.). Lewis Publishers, pp. 213228.

Small, H., Stevens, T. S. \& Bauman, W. C. 1975 Novel ion exchange chromatographic method using conductimetric detection. Analytical Chemistry 47, 1801-1809

Speziale, B. J., Schriener, S. P., Giammatteo, P. A. \& Schindler, J. E. 1984 Comparison of N,N-dimethylformamide, dimethyl sulfoxide and acetone for extraction of phytoplankton chlorophyll. Canadian Journal of Fisheries and Aquatic Sciences 41, $1519-1522$

Stoecker, D., Michaels, A. E. \& Davis, L. H. 1987 Large proportion of marine planktonic ciliates found to contain functional chloroplasts. Nature 326, 790-792

Stoecker, D., Taniguchi, A. \& Michaels, A. E. 1989 Abundance of autotrophic, mixotrophic and heterotrophic planktonic ciliates in shelf and slope waters. Marine Ecology Progress Series 50, 241-154

Throndsen, J. 1976 Occurrence and productivity of small marine flagellates. Norwegian Journal of Botany 23, 269-293

Tranvik, L. J. 1988 Availability of dissolved organic carbon for planktonic bacteria in oligotrophic lakes of different humic content. Microbial Ecology 16, 311-322

Vadstein, O., Jensen, A., Olsen, Y. \& Reinertsen, H. 1988 Growth and phosphorus status of limnetic phytoplankton and bacteria. Limnology and Oceanography 33, 489503

Veen, A. 1991 Ecophysiological studies on the phagotrophic phytoflagellate Dinobryon divergens Imhof. Ph.D. thesis, Universiteit van Amsterdam.

Wetzel, R. G. 1975 Limnology. W.B. Saunders Company, Philadelphia.

Wetzel, R. G. 1991 Limnological Analyses. Springer-Verlag, New York 
Wood, E., Armstrong, F. \& Richards, F. 1967 Determination of nitrate in sea water by cadmium copper reduction to nitrite. Journal of the Marine Biological Association of the United Kingdom 47, 23-31 


\section{CHAPTER 4}

The Importance of Phagotrophy in the Nutrition of Mixotrophic Nanoplankton in an Adirondack Seepage Pond 


\begin{abstract}
The importance of phagotrophy for the growth and survival of mixotrophic algae was investigated in a meso-oligotrophic seepage pond located in the west-central region of the Adirondack Mountains, NY,. A six day in situ experiment was conducted in enclosures to examine the effect of changes in bacterial abundance (with addition of labile organic carbon), inorganic nutrient supply and light intensity on algal phagotrophy. Dinobryon and other unidentified solitary and colonial algae exhibited phagotrophic behavior during the experiment. Dinobryon comprised a large fraction of the phototroph assemblage at the end of the experiment in treatments with higher bacterial abundances and in low light. Experimental manipulations did not appear to significantly affect the relative abundance of the unidentified solitary mixotrophs. Unidentified colonial mixotrophs appeared to be favored at in situ light levels with increased bacterial abundances.
\end{abstract}

The phagotrophic activity of Dinobryon was examined separately. Activity (\% of cells found to be ingesting fluorescently labeled bacteria) was low in the presence of elevated concentrations of dissolved inorganic $\mathrm{N}$ and $\mathrm{P}$ at in situ light levels, but high in controls and glucose amended enclosures without added $\mathrm{N}$ and $\mathrm{P}$. In low light, phagotrophic activity was also high. These results are in good agreement with previous hypotheses (Veen, 1991; Caron et al., 1992) that have suggested the primarily role of phagotrophy in Dinobryon may be to provide specific growth factors or major nutrients, and that under light limiting conditions this trophic behavior may also allow for the survival of this alga. Observations indicated that phagotrophic activity in the Dinobryon population persisted at a low level even in the presence of favorable phototrophic conditions (i.e. in situ light with added $\mathrm{N}$ and $\mathrm{P}$ ), but was higher when $\mathrm{N}$ and $\mathrm{P}$ were not added. These results may indicate that consumption of a few bacteria cell ${ }^{-1} \mathrm{~d}^{-1}$ may be important for continued good growth of Dinobryon regardless of light intensity or 
nutrient availability, but that during periods of low nutrient availability, phagotrophic uptake of bacteria may serve as an important source of $\mathrm{N}$ or $\mathrm{P}$. It was therefore hypothesized that nutrient acquisition is probably an important secondary function of phagotrophy in Dinobryon that may influence grazing activity, but that the primary function of phagotrophic behavior may be to provide essential growth factor(s). 


\section{INTRODUCTION}

Mixotrophic algae are unicellular algae that combine autotrophic and heterotrophic modes of nutrition, commonly phototrophy and phagotrophy. Algal species in more than 25 genera (Chysophyta, Pyrrhophyta and Cryptophyta) have been reported to exhibit phagotrophy, and pigmented members of other flagellate taxa containing morphologically similar chlorotic and apochlorotic species may also be capable of phagotrophy (Sanders \& Porter, 1988, for summary of references). Phagotrophy therefore apparently is widespread among phytoflagellates, yet its potential importance in algal growth and survival has been examined in only a few species. Based on these studies, several hypotheses have been put forward to explain the role of phagotrophy in algal nutrition. These include acquisition of carbon, major nutrients ( $\mathrm{N}$ or $\mathrm{P}$ ) or specific growth factors (e.g. vitamins, phospholipids).

Phagotrophy is the primary source of carbon used for metabolism and growth in some mixotrophic algae. Photosynthesis in these algae appears to be important as a survival strategy under poor heterotrophic conditions (Andersson et al., 1989; Sanders et al., 1990). For example, Sanders et al. (1990) found in studies with the mixotrophic chrysophyte Poterioochromonas malhamensis that this primarily heterotrophic species was able to increase chlorophyll production and survive phototrophically when bacterial prey densities fell below a grazing threshold of approximately $1 \times 10^{6} \mathrm{ml}^{-1}$. At bacterial concentrations above the grazing threshold, however, photosynthesis did not contribute more than $7 \%$ to the alga's total carbon budget. Similar trophic behavior has also been observed in some species of Ochromonas (Fenchel, 1982; Andersson et al., 1989).

Other species of mixotrophic algae are obligate photophagotrophs that require both photosynthesis and phagotrophy for their growth and survival. Phagotrophy has been hypothesized to provide these algae with a source of organic compounds that they are otherwise unable to synthesize but which they require for phototrophic growth. 
Uroglena americana is a freshwater red tide chrysophyte that appears to exhibit this trophic strategy. Kimura and Ishida (1986) reported that light and ingestion of bacteria were both necessary for growth of this alga. Based on laboratory fractionation studies, they determined that bacterivory by $U$. americana was associated with acquisition of an essential phospholipid required for growth (Kimura \& Ishida, 1989).

Phagotrophy might also provide mixotrophic algae with major nutrients (N \& P). This trophic strategy has been hypothesized for mixotrophic algae in oligotrophic environments (Veen, 1991). Support for this hypothesis has been provided by a study of several species of mixotrophic algae present during two toxic algal blooms that occurred off the coast of Norway (Nygaard \& Tobiesen, 1993). The authors found that low orthophosphate concentration, a feature of the blooms, resulted in higher bacterial uptake rates in a number of the algae tested. Further evidence is provided in Chapter 2. Higher abundances of mixotrophic algae occurred in oligotrophic surface waters at several stations in the Sargasso Sea. Based on the results of experimental manipulations conducted with surface water samples, it was suggested that mixotrophic algae may supplement major nutrients via phagotrophy, and therefore hypothesized that this behavior may allow these algae to survive in competition with other phototrophs during periods of nutrient limitation (Chapter 2). Other investigators have also suggested that supplementation of major nutrients ( $\mathrm{N}$ or $\mathrm{P}$ ) may be one reason for phagotrophy in Dinobryon, a freshwater Chrysophyte commonly found in oligotrophic lake environments (Veen, 1991; Caron et al., 1992).

Until recently, the literature contained only anecdotal accounts of algal phagotrophs in nature. Little attention was directed towards the potential role of mixotrophic algae in energy and nutrient flow through planktonic food webs. With recent advancements in microbial methodology though (Porter \& Feig, 1980; Caron, 1983; Sherr \& Sherr, 1983; Sherr et al., 1987; Kemp et al., 1993), and recognition of the importance of microheterotrophic processes in planktonic food webs (Pomeroy, 1974; Azam et al., 
1983), there has been a renewed interest in algal phagotrophy, and ecologists have begun to establish the importance of these algae in aquatic systems. Several studies have indicated that phagotrophic algae may dominate the phototroph assemblages of some plankton communities (Bird \& Kalff, 1986; Bird \& Kalff, 1989; Berninger et al., 1992, also Chapters $2 \& 3$ ). In addition to dominating photosynthetic processes on occasion, mixotrophic algae may also contribute significantly to total bacterivory. For example, in several freshwater lake environments, algal bacterial consumption was found to exceed consumption by the heterotrophs (Bird \& Kalff, 1986). Four species of the Chrysophyte Dinobryon, constituting a large biomass in Lac Cromwell, Quebec, were found to be major consumers of bacteria. In Quinn Bay, Lac Memphremagog, Vermont-Quebec, they removed more bacteria from the water column than the crustaceans, rotifers and ciliates combined. In the surface waters of Lake Oglethorpe, Georgia, grazing by the autotrophic community constituted $55 \%$ of total bacterial grazing of all microflagellates, ciliates, rotifers and crustaceans combined (Porter, 1988; Sanders et al., 1989). While these studies demonstrate that algal phagotrophy can at times account for a substantial portion of the total grazing pressure on bacterioplankton, the role of algal phagotrophy in the flow of energy and materials through planktonic food webs is poorly understood.

A survey of nine Adirondack seepage ponds was conducted to provide information on the abundance and distribution of mixotrophic algae (Chapter 3). During this study, mixotrophic algae, most notably Dinobryon, were found to be important contributors $(>25 \%)$ to the phototrophic nanoplankton assemblage in the epilimnion and metalimnion of a small (area, $6 \mathrm{ha} ; \mathrm{Z}_{\max }, 18 \mathrm{~m}$ ), meso-oligotrophic (total P, $\sim 30 \mu \mathrm{g} \mathrm{L}^{-1}$; total N, $180 \mu \mathrm{g} \mathrm{L}^{-1}$; DOC, $\sim 5.7 \mathrm{mg} \mathrm{L}^{-1}$, see Chapter 3) pond (Wheeler Pond) located in the west-central region of the Adirondack Mountains near Old Forge, NY. The results from a field manipulation experiment designed to provide information on the importance of light, nutrients and prey density in determining the abundance and phagotrophic 
activity of the mixotrophic nanoplankton population in the epilimnion of this pond is now presented. 


\section{METHODS}

The experiment was conducted in situ with whole water samples that were subdivided, treated and incubated in enclosures for a period of 6 days. Abundances of the microbial populations, including mixotrophic nanoplankton, were monitored for changes with respect to additions of inorganic nutrients and/or labile organic carbon, and reduced light intensity. Water was collected from a depth of $1 \mathrm{~m}$ using a $4 \mathrm{~L}$ Van Dorn bottle and pooled in $20 \mathrm{~L}$ carboys. Subsamples were immediately removed and preserved to a final concentration of $1 \%$ gluteraldehyde in order to establish the initial population densities of heterotrophic picoplankton (bacteria $<2 \mu \mathrm{m}$ in size) and phototrophic and heterotrophic nanoplankton (algae and protozoa $2-20 \mu \mathrm{m}$ in size). All population counts were performed by epifluorescence microscopy at 1000x magnification (Porter \& Feig, 1980; Sherr et al., 1993).

Water was removed from the carboys in $3.5 \mathrm{~L}$ aliquots, placed in duplicate $4 \mathrm{~L}$ clear polycarbonate enclosures and treated as described below.

\footnotetext{
C Control, water with no additions

G Water with additions of glucose $\left(2.5 \mathrm{mg} \mathrm{L}^{-1}\right.$ final conc.) every other day

NP Water with additions of $\mathrm{N}^{-\mathrm{NH}_{4}}+(20 \mu \mathrm{M}$ final conc.) and $\mathrm{P}^{-\mathrm{PO}_{4}}{ }^{-3}$ ( $2 \mu \mathrm{M}$ final conc.) every other day

GNP Water with additions of glucose, $\mathrm{N}$ and $\mathrm{P}$ every other day at above concentrations

LL Water at low light intensity ( $<5 \%$ incident light) without inorganic or organic additions

LLGNP Water at low light intensity with additions of glucose, N and $\mathrm{P}$ every other day at above concentrations
}

It was hypothesized that several specific responses would be accomplished by the manipulations. Glucose was added to stimulate bacterial growth. In the treatment with added glucose only, stimulation of the bacterial assemblage would be expected to increase their uptake of dissolved nutrients thereby resulting in increased competition for 
nutrients with the phototroph assemblage. Reduced dissolved nutrient concentrations may potentially favor mixotrophic algae that are able to acquire nutrients by consumption of bacteria. The purpose of combining additions of glucose with additions of inorganic $\mathrm{N}$ and $\mathrm{P}$ was to increase bacterial abundances without creating nutrient limiting conditions for the phototrophs. Mixotrophic species in enclosures with these additions may benefit from the higher prey abundances. $\mathrm{N}$ and $\mathrm{P}$ were added alone to stimulate the growth of phototrophs without stimulating bacteria. Only primarily heterotrophic species of mixotrophs and obligate photophagotrophs would presumably continue to consume bacteria in enclosures treated in this way. Finally, light intensity was reduced to decrease photosynthetic rate, and nutrients and glucose were added to stimulate the heterotrophic nanoplankton and bacteria in these enclosures. Algae capable of supplementing photosynthetic carbon by consuming bacterial $\mathrm{C}$ may be favored in the low light treatment without added $\mathrm{C}, \mathrm{N}$ or $\mathrm{P}$, while primarily heterotrophic algae would presumably be favored in the presence of higher bacterial abundances and low light expected in the LLGNP treatment.

On day six, population abundances of bacteria and heterotrophic and phototrophic nanoplankton were determined again in each enclosure as described earlier to examine the response of these populations to each experimental manipulation. The following procedure also was carried out at the beginning and end of the six-day incubation experiment to determine the responses of the mixotrophic nanoplankton population to experimental manipulations. Mixotrophic nanoplankton abundances were determined by removing $200 \mathrm{ml}$ subsamples from each experimental enclosure, placing them in $250 \mathrm{ml}$ clear polycarbonate vessels and incubating them in situ with fluorescently labeled prey for a period of five hours to trace ingestion by algae. Mixotrophic algae are defined operationally by this method as cells that contain both autofluorescent chloroplasts and ingested fluorescently labeled prey. Fluorescently labeled bacteria (FLB) prepared from Pseudomonas halodurans according to the method 
of Sherr et al. (Sherr et al., 1987) were used as tracers of ingestion in this experiment. FLB were added at a final concentration equal to $1 \times 10^{6} \mathrm{FLB} \mathrm{ml}^{-1}$. Immediately after the addition of fluorescently labeled prey the containers were gently swirled to distribute the tracer, and samples were removed and preserved to establish the initial numbers of labeled prey. Following the incubations, samples were preserved with $\mathrm{NiCl}_{2}(0.05 \%$ to prevent egestion; Waterbury, pers. comm.) followed by gluteraldehyde (1\%) and examined by epifluorescence microscopy at 1000x magnification to establish the percent of phototrophic cells that were phagotrophic.

The percent of phototrophic cells that were phagotrophic was determined by observing more than 200 individual phototrophic nanoplankton (chloroplast-bearing cells $2-20 \mu \mathrm{m}$ in size) for ingested FLB as they were encountered in each $\mathrm{T}_{\text {final }}$ FLB incubated sample during the microscopical examinations. The method is based on two assumptions: (1) fluorescently labeled prey are ingested at the same rate as natural prey, and (2) all mixotrophic algae actively phagocytize prey during experiments. Thus, in cases where a specific mixotrophic alga is recognizable under epifluorescence, the percent of these cells with ingested FLB provides a measure of phagotrophic activity for the alga. In an algal assemblage of unknown composition though, the percent of cells with ingested FLB may be used to provide a lower limit estimate of the relative abundance of mixotrophic algae, but may not accurately reflect the phagotrophic activity of the mixotroph population, since both phototrophic and mixotrophic algae may comprise the assemblage.

Comparisons of day 0 mean abundances and \% of phagotrophically active algae with day 6 mean values were performed (T-test, $\mathrm{P}<0.05)$. Statistical contrasts were then conducted using the results from day 6 , and treatments were contrasted to controls using transformed data (ln or $-1 / x)$. Significant differences were determined at a significance level of $\mathrm{P}<0.05$. 


\section{RESULTS}

Abundances of bacteria and heterotrophic and phototrophic nanoplankton in controls were not found to be significantly different $(\mathrm{P}<0.05)$ between day 0 and day 6 (Table 4.1). Heterotrophic bacterial abundance remained stable in controls over the course of the six day incubation period (2.4-2.8 $\times 10^{6} \mathrm{ml}^{-1}$; Table 4.1). Although significant differences were not observed, the mean heterotrophic nanoplankton abundance in controls increased $>4$ fold and the mean total phototrophic nanoplankton abundance decreased $\sim 1.5$ fold in controls during the experiment. Within the phototrophic nanoplankton assemblage, it was possible to identify the mixotrophic chrysophyte Dinobryon as well as other phototrophic algae including Dactylococcopsis, Gleocystis, cryptophytes and dinoflagellates. Other phototrophic nanoplankton could not be identified using epifluorescence microscopy and thus, were grouped according to whether they existed as solitary or colonial forms. Mean abundances of Dinobryon decreased more than an order of magnitude in controls during the experiment (Table 4.1). Mean abundances of Dactylococcopsis, cryptophytes, dinoflagellates and unidentified solitary PNAN also decreased in controls during the experiment. Differences between day 0 and day 6 values for Dinobryon and these other algae were not statistically significant, though, due to large variances and the patchy nature of some colonial algae. Mean abundances of Gleocystis and unidentified colonial PNAN in controls did not exhibit large changes in their abundances over the course of the six day incubation period (Table 4.1).

Of the algae that could be identified using epifluorescence microscopy, only the known mixotroph Dinobryon was observed with ingested FLB. Unidentified solitary and colonial individuals also exhibited phagotrophic activity. The percent of Dinobryon cells that were phagotrophically active remained constant in controls over the course of the experiment (Table 4.2). The percent of unidentified solitary and colonial PNAN that 
Table 4.1. Population abundances $( \pm 1$ SD) in controls determined at the beginning and end of a 6 day experimental incubation performed in Wheeler Pond, Adirondack Mtns., NY from 7-13 August, 1992. Based on a T-test of the means (P-value=0.05), abundances on Day 6 were not significantly different from abundances on Day 0.

\section{$\begin{array}{lll}\text { Cell Type } & \text { Day } 0 & \text { Day } 6\end{array}$}

Bacteria $\left(x 10^{6} \mathrm{ml}^{-1}\right)$

$2.82 \pm 0.34$

$2.38 \pm 0.20$

Heterotrophic Nanoplankton $\left(\times 10^{4} \mathrm{ml}^{-1}\right)$

$1.21 \pm 0.44$

$5.44 \pm 0.10$

Phototrophic Nanoplankton $\left(\times 10^{4} \mathrm{ml}^{-1}\right)$

$3.56 \pm 2.31$

$1.90 \pm 0.90$

Dinobryon $\left(\mathrm{x} 10^{2} \mathrm{ml}^{-1}\right)$

$219.60 \pm 220.95$

$17.08 \pm 19.63$

Dactylococcopsis (x10 $\left.\mathrm{ml}^{-1}\right)$

$6.86 \pm 6.92$

$1.07 \pm 1.51$

Gleocystis $\left(\times 10^{2} \mathrm{ml}^{-1}\right)$

$29.97 \pm 11.42$

$41.10 \pm 2.26$

Cryptophytes $\left(\mathrm{x} 10^{2} \mathrm{ml}^{-1}\right)$

$1.25 \pm 1.55$

$0.00 \pm 0.00$

Dinoflagellates $\left(\times 10^{2} \mathrm{ml}^{-1}\right)$

$0.40 \pm 0.80$

$0.00 \pm 0.00$

Unidentified Solitary PNAN (x10 $\left.\mathrm{ml}^{-1}\right)$

$67.61 \pm 36.10$

$22.42 \pm 7.55$

Unidentified Colonial PNAN $\left(\times 10^{2} \mathrm{ml}^{-1}\right)$

$27.13 \pm 40.12$

$21.35 \pm 13.59$ 
Table 4.2. Percent ( \pm 1 SD) of phototrophic nanoplankton that were phagotrophically active in controls determined at the beginning and end of a 6 day experimental incubation performed in Wheeler Pond, Adirondack Mtns., NY from 7-13 August, 1992. Significant differences $(\mathrm{P}$-value $=0.05$ ) between Day 0 and Day 6 values were not detectable.

\begin{tabular}{lcc} 
Cell Type & Day 0 & Day 6 \\
\hline \% of Dinobryon & $49.35 \pm 25.17$ & $49.00 \pm 10.75$ \\
$\%$ of Unidentified Solitary PNAN & $19.68 \pm 9.64$ & $3.95 \pm 2.19$ \\
$\%$ of Unidentified Colonial PNAN & & $0.00 \pm 0.00$ \\
\hline
\end{tabular}


were mixotrophic decreased in controls during this experiment, although significant differences again were not detected.

Bacterial abundances (BACT) in enclosures that received additions of nitrogen and phosphorus (NP) or glucose, $\mathrm{N}$ and $\mathrm{P}$ (GNP, LLGNP) increased more than 3 fold relative to controls (Fig. 4.1a). Mean bacterial abundances for these treatments ranged from $7.4 \times 10^{6} \mathrm{BACT} \mathrm{ml}^{-1}$ to $8.4 \times 10^{6} \mathrm{BACT} \mathrm{ml}-1$. Smaller increases in the abundances of bacteria were observed in the glucose treated enclosures $(\mathrm{G}$, increase of $<65 \%)$ and the low light enclosures without added carbon or nutrients (LL, increase of $<30 \%$ ). Abundances in untreated enclosures (C) were $2.4 \times 10^{6} \mathrm{BACT} \mathrm{ml}^{-1}$. Assuming that a similar grazing pressure on bacterioplankton existed in all enclosures, these results indicate that bacterial production may have been limited by $\mathrm{N}$ or $\mathrm{P}$, or co-limited by carbon substrate and $\mathrm{N}$ or $\mathrm{P}$, rather than by carbon substrate alone.

Heterotrophic nanoplankton (HNAN) responded similarly to the bacteria during the study (Fig. 4.1b). HNAN abundances increased between 2.4 fold and 5.4 fold relative to controls $\left(5.4 \times 10^{3} \mathrm{HNAN} \mathrm{ml}^{-1}\right)$ in all five treatments, presumably due to the increase in bacterial prey abundance that occurred in the treated enclosures. Maximum abundances were observed in the NP, GNP and LLGNP treatments with values between $2.4 \times 10^{4}$ and 2.9x $10^{4} \mathrm{HNAN} \mathrm{ml}^{-1}$.

The total PNAN abundance in treatments ranged from $\sim 1.2 \times 10^{4} \mathrm{ml}^{-1}$ to $>4.1 \times 10^{4}$ $\mathrm{ml}^{-1}$ (Fig. 4.1c). No significant differences were detectable between total PNAN abundances in treatments and controls at the end of the experiment. Mean total PNAN abundances in low light treatments were $~ 30 \%$ (LL) and $~ 10 \%$ (LLGNP) lower than controls. Their abundances in enclosures with added glucose only and with added inorganic nutrients only were $\sim 20 \%$ (G) and $\sim 40 \%$ (NP) higher than in controls. In enclosures that received additions of glucose together with inorganic nitrogen and phosphorus, total PNAN abundances were approximate $~ 2$ fold higher than in controls. 

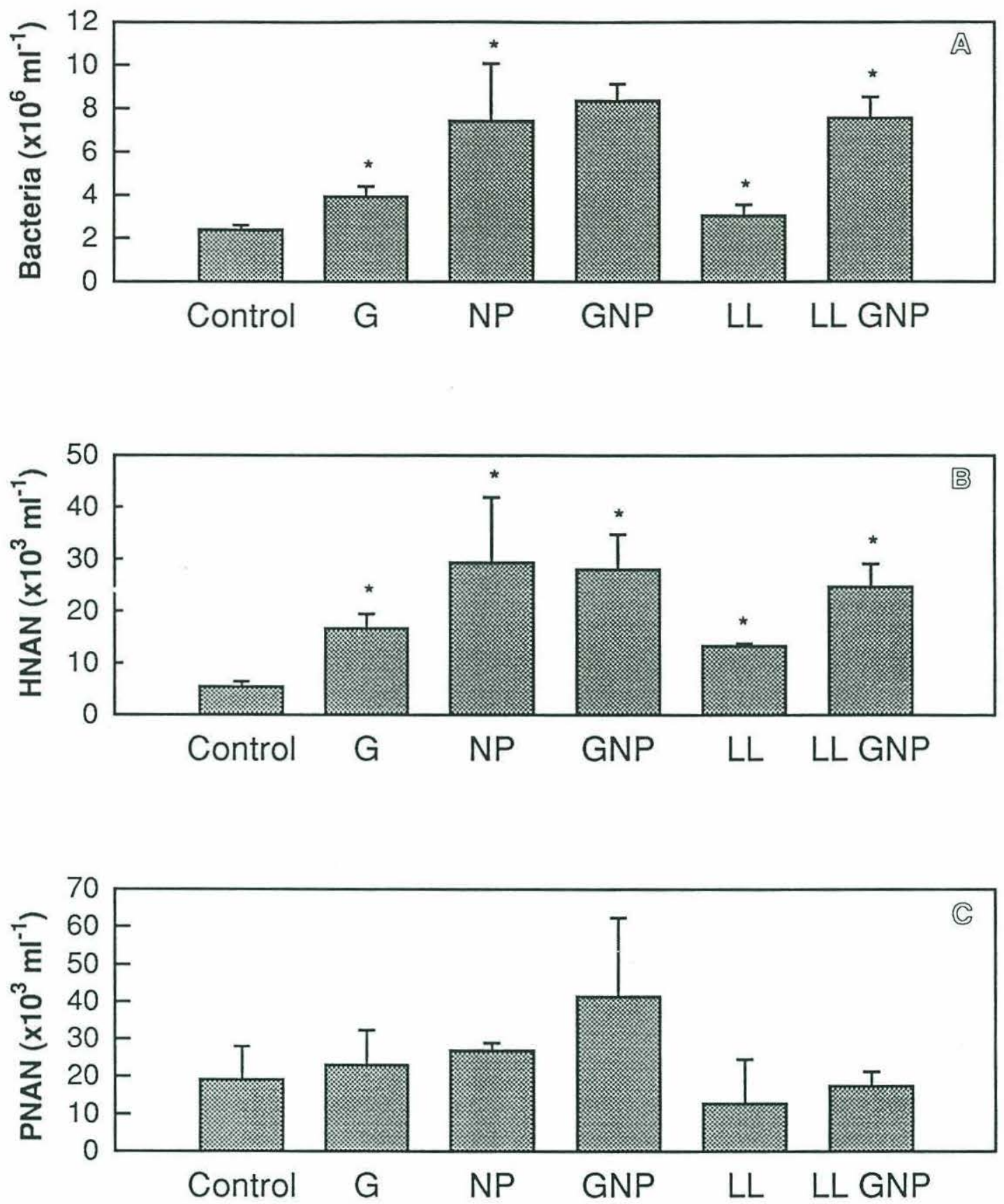

Figure 4.1. Mean population abundances $( \pm 1 \mathrm{SD}$ ) of bacteria (A), heterotrophic nanoplankton (B), and phototrophic nanoplankton (C) in controls, glucose (G), nitrogen+phosphorus (NP), glucose+nitrogen+phosphorus (GNP), low light (LL) and light with glucose+nitrogen+phosphorus (LLGNP) treatments at the end of a 6 day experimental incubation conducted from 7-13 August 1992 in Wheeler Pond, Adirondack Mtns., NY. Phototrophic nanoplankton includes solitary and colonial forms with cells sizes $<20 \mu \mathrm{m}$ in diameter. Significant differences between treatments and controls are indicated by :*" (P-value $=0.05)$. See text for details of treatments. 
The combined abundance of Dactylococcopsis, Gleocystis, cryptophytes and dinoflagellates (algae not found to ingest prey during this study) fell to less than $20 \%$ $\left(<1 \times 10^{3} \mathrm{ml}^{-1}\right)$ of control abundances in enclosures receiving combined additions of glucose, nitrogen and phosphorus (GNP, LLGNP; Fig. 4.2a). In the untreated low light enclosures, controls, and enclosures with added glucose (G) or added N and P only (NP), abundances were similar to abundances in controls $\left(\sim 4 \times 10^{3} \mathrm{ml}^{-1}\right)$. Algal groups that contained phagotrophically active algae responded differently from non-phagotrophic algae (Fig. 4.2b-d). Mean abundances of Dinobryon were 4.3 to 4.8 times higher than controls in treatments incubated at ambient light intensity and provided with additions of inorganic nutrients and/or glucose (G, NP, GNP). Smaller increases in Dinobryon abundances ( 2.5 fold) occurred in response to low light (LL, LLGNP; Fig. 4.2b). Due to the highly patchy nature of Dinobryon (colonial genus) though, these differences were not statistically significant.

The unidentified solitary PNAN responded similarly to Dinobryon (Fig. 4.2d). Abundances increased 3.3 to 5.3 fold in the G, NP and GNP treatments, while abundances of unidentified solitary PNAN were similar to controls in the low light treatments (LL, LLGNP). In contrast, unidentified colonial PNAN abundances increased significantly in the treatment with added glucose and inorganic nutrients incubated in ambient light (6.5 fold in GNP; Fig. 4.2e). In enclosures with added glucose only (G) or added inorganic $\mathrm{N}$ and $\mathrm{P}$ only (NP), abundances of unidentified colonial PNAN changed only slightly relative to controls (G, $\sim 66 \%$ increase; NP, $30 \%$ decrease). Almost no unidentified colonial PNAN survived in the two low light treatments.

Dinobryon was phagotrophically active in all the treatments. A large percentage of Dinobryon cells (40-50\%) were actively ingesting bacteria in the controls (C), the treatment with added glucose (G), and in both low light treatments (LL, LLGNP). Phagotrophic activity by Dinobryon was much lower $(<10 \%)$ in ambient light treatments enriched with dissolved N and P (NP \& GNP; Fig. 4.3a). Unidentified solitary algal 


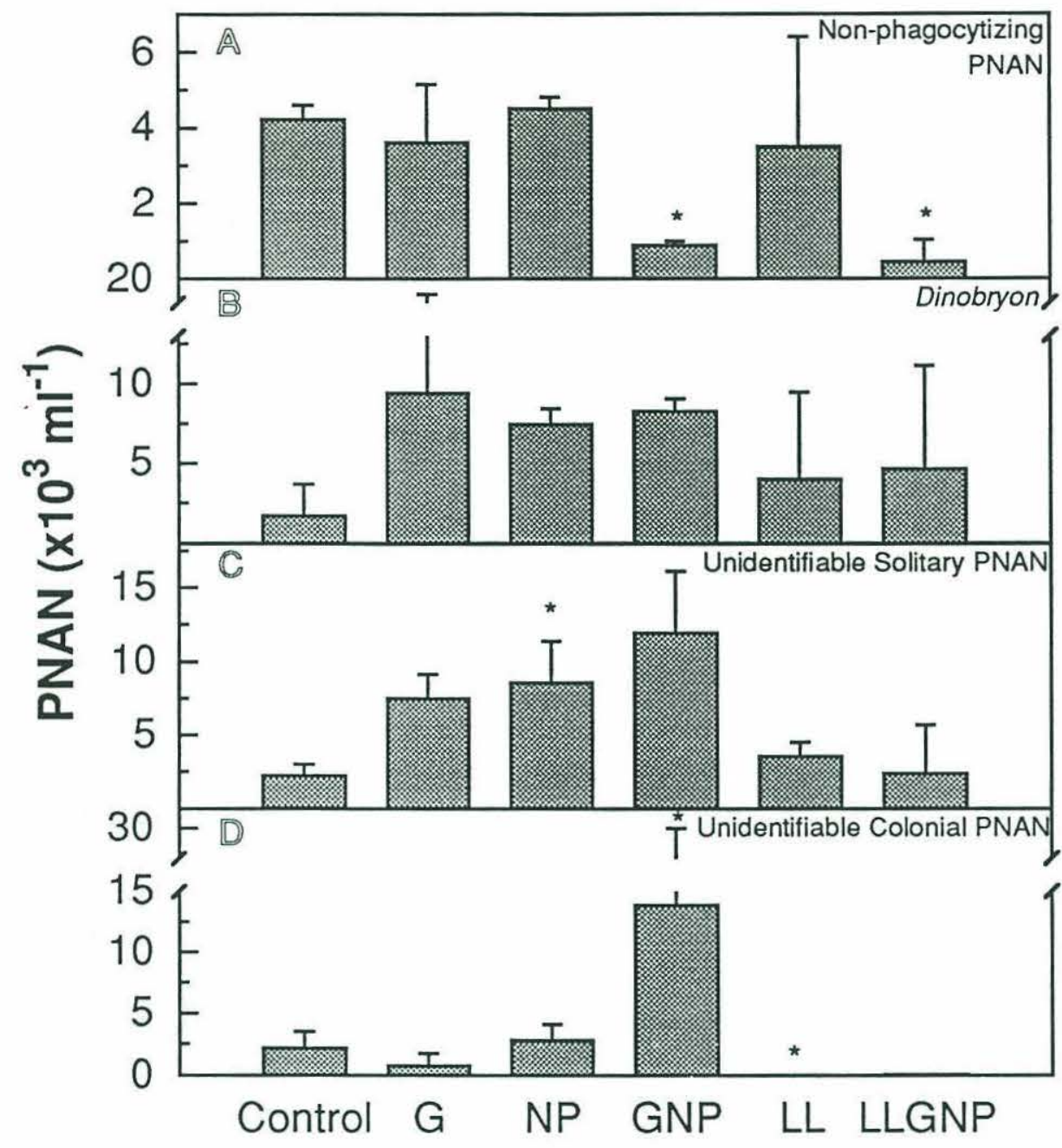

Figure 4.2. Combined abundance ( $\pm 1 \mathrm{SD})$ of nanoplanktonic phototrophs in groups that were not phagotrophic (A), total abundance ( $\pm 1 \mathrm{SD}$ ) of Dinobryon (B), total abundance of unidentified solitary phototrophic nanoplankton $(C)$ and total abundance of unidentified colonial nanoplankton (D) in controls, glucose (G), nitrogen+ phosphorus (NP), glucose+nitrogen+phosphorus (GNP), low light (LL) and low light with glucose+nitrogen+phosphorus (LLGNP) at the end of a 6 day experimental incubation conducted from 7-13 August 1992 in Wheeler Pond, Adirondack Mtns., NY. Significant differences between treatments and controls are indicated by "*" $(\mathrm{P}$-value $=0.05)$. See text for details of treatments. 

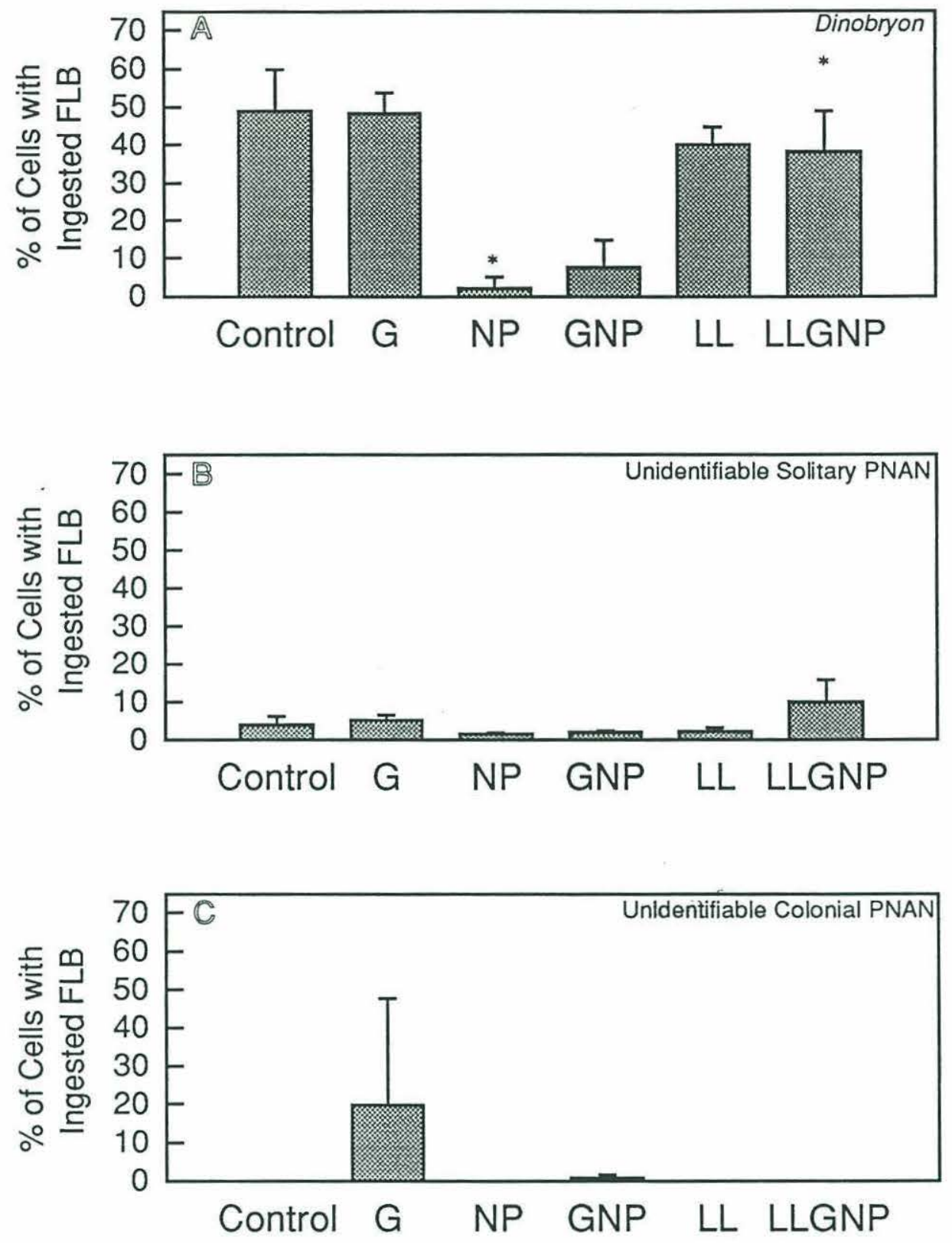

Figure 4.3. Percent ( $\pm 1 \mathrm{SD}$ ) of Dinobryon cells that were phagotrophically active (A), and percent $( \pm 1$ SD) of solitary (B) and colonial (C) phototrophic nanoplankton that were mixotrophic in controls, glucose (G), nitrogen+phosphorus (NP), glucose+ nitrogen+phosphorus (GNP), low light (LL) and low light with glucose+nitrogen+ phosphorus (LLGNP) treatments at the end of a 6 day experimental incubation conducted from 7-13 August 1992 in Wheeler Pond, Adirondack Mtns, NY. Significant differences between treatments and controls are indicated by "*" $(\mathrm{P}$-value $=0.05)$. See text for details of treatments. 
phagotrophs were observed in all five treatments and in controls, similar to Dinobryon. However, a very small percentage (generally $<5 \%$ ) of the total unidentified solitary PNAN assemblage was mixotrophic in each treatment (Fig. 4.3b). Likewise, little or no mixotrophs were detectable among the unidentified colonial PNAN assemblage in most of the treatments (Fig. 4.3c). In the treatment with added glucose, however, approximately $20 \%$ of the unidentified colonial PNAN appeared to be phagotrophic.

A persistent problem with enclosure experiments is that a limited number of treatments are possible and the investigator must often choose between increasing the number of treatments or increasing the number of replicates. The data from this experiment suffered from a high degree of variability due primarily to too few replicates, but also due to difficulties in counting as a consequence of large amounts of particulate material in the samples and the patchy distribution of some colonial algae. Transformations of the data did not prove helpful in homogenizing the variances. 


\section{DISCUSSION}

Importance of mixotrophic unidentified solitary and colonial algae

The dominant forms of nanoplanktonic algae in an earlier study of the phytoplankton composition in the epilimnion of Wheeler Pond included Synura, Gleocystis, Chlamydomonas, Dactylococcopsis, Chromulina and Dinobryon (Saunders, 1992). Gleocystis, Dactylococcopsis and Dinobryon were also identified during this study. Of the solitary forms identified by Saunders, Chromulina has been observed to ingest particles (Hutner \& Provasoli, 1951; Bird \& Kalff, 1987). This alga may have comprised some portion of the unidentified solitary mixotroph population during this study. Ingestion by unidentified colonial phototrophs was also observed in the enclosures. While Synura is not known to ingest particles (D.A. Caron, WHOI, pers. comm.), Uroglena and Chrysosphaerella are capable of phagotrophy (Sanders \& Porter, 1988). Uroglena-like and Chrysosphaerella-like colonies were observed during this experiment and these morphotypes were found to be ingesting prey. It is therefore possible that some portion of the unidentified colonial mixotroph assemblage was comprised of these mixotrophic species at the time of this study.

The unidentified solitary PNAN assemblage in each of the treatments was comprised of relatively few mixotrophs $(<5 \%)$ at the end of the experiment. There abundances at the beginning of the experiment were apparently higher, though, and it may be that negative effects from containment masked the potential effects of bacterial abundance, nutrient concentration and/or light in determining the relative abundance of unidentified solitary mixotrophs in this pond. Unidentified colonial mixotrophs did not persist in controls and containment may have had a large negative effect on their survival. They did, however, persist in two treatments (G \& GNP), and comprised $~ 20 \%$ of the unidentified colonial assemblage in these two treatments. It is important to note that 
while all of the Dinobryon cells present during the study were presumably capable of phagotrophy, no more than $50 \%$ of the individuals of this mixotrophic chrysophyte genus were ever found to be phagotrophically active in any of the treatments. Assuming that the unidentified mixotrophic colonial algae in this pond also had a similar distribution of cells with ingested FLB, the relative abundance of unidentified colonial mixotrophs could have been twice as large in the G and GNP treatments than was reported, and they may also have been present at very low abundances in the other treatments. Nearly $40 \%$ of the unidentified colonial PNAN could therefore have been mixotrophic in the glucose amended treatment. It is therefore possible that additions of glucose in the absence of added nutrients significantly influenced the relative abundance of unidentified colonial mixotrophs. Higher abundances of bacteria and a possible reduction in the availability of $\mathrm{N}$ or $\mathrm{P}$ in the glucose amended treatment may have favored some colonial mixotrophic forms.

Importance of phagotrophy in the nutrition of Dinobryon

The mixotrophic chrysophyte Dinobryon comprised a large fraction of the phototroph assemblage during this study. This alga is typically a member of the phytoplankton assemblage in dimictic lakes and ponds characterized by circum-neutral $\mathrm{pH}$ and low nutrient loading. During periods of stratified water, Dinobryon frequently dominates the nanoplankton assemblage in these systems (Sandgren, 1988). Phagotrophic behavior was first described in this alga in 1911 by Pascher. Ecologists did not begin to focus studies on the role of phagotrophy in the nutrition of Dinobryon, or the influence of environmental factors on the trophic behavior of this alga, until much later however. Such studies were initiated only after Bird and Kalff (1986; 1989) demonstrated that Dinobryon could have an important impact on grazing and that this 
alga may supplement up to $50 \%$ of its photosynthetic carbon by consuming bacteria under low light conditions.

Several hypotheses have since been proposed to explain the importance of phagotrophy in the growth and survival of Dinobryon. Based on laboratory studies with D. divergens, Veen (1991) hypothesized the following: (1) that Dinobryon is facultatively phagotrophic and does not have an absolute need for bacteria; (2) that phagotrophic activity in Dinobryon is dependent on the type of limiting condition (e.g. elevated phagotrophic activity with light limitation vs. reduced phagotrophic activity with iron limitation) and not on the intensity of the limitation; and (3) that the main advantage of phagotrophic behavior in Dinobryon must be nutrient acquisition, not carbon acquisition. Veen concluded that to experience an advantage from carbon acquired from bacteria, Dinobryon must grow under carbon- and light-limited conditions. Yet, Dinobryon normally occurs in rather clear, well-lighted oligotrophic phosphorus-deficient waters. Based on the studies with $D$. divergens, Veen suggested that light may influence phagotrophic behavior, but reasoned that the most likely benefit from bacteria must be phosphorus because the $\mathrm{C}: \mathrm{P}$ ratio of bacteria was considerably less than that of phytoplankton (Vadstein et al., 1988) and the occurrence of Dinobryon was typically associated with low phosphorus conditions.

Caron et al. (1992) also examined the importance of bacterivorous behavior in laboratory studies with axenic and bacterized cultures of D. cylindricum. Based on their experiments, they concluded that D. cylindricum is an obligate phototroph, but also requires bacteria for sustained vigorous growth. They further hypothesize based on their results, that the primary function of phagotrophic behavior in this species may be to provide essential growth factor(s) or major nutrients for phototrophic growth, but that this behavior may also allow for the survival of individuals when light is limiting.

The results of this study provide the first, although preliminary, field evidence in support of hypotheses that have suggested that the primary function of phagotrophy in 
Dinobryon is as a source of specific growth factors or major nutrients for photosynthesis, and that this behavior may also allow for the survival of this alga in low light. Dinobryon was found to be a relatively important contributor to the phototroph assemblage in low light treatments, and phagotrophy appeared to play an important role in their nutrition under these conditions. In both low light treatments, regardless of the presence or absence of added nutrients, phagotrophic activity was high. Little or no increase in population abundance was apparent, though. These results are in good agreement with the results from the study by Caron et al. (1992). They found that in short photoperiod or very low light intensity, $D$. cylindricum consumed bacteria and was able to maintain its population densities, but did not increase in population density. Under these conditions the net efficiency of incorporation for $\mathrm{C}, \mathrm{N}$ and $\mathrm{P}$ into algal biomass was zero.

In addition, high abundances of Dinobryon were observed in treatments that were incubated in ambient light with added glucose and/or major nutrients. Under conditions that presumably should have favored purely phototrophic species (ambient light and added major nutrients), Dinobryon was an important member of the phototroph assemblage, and only exhibited a low level of phagotrophic activity. Dinobryon was also an important contributor to the phototroph assemblage in the treatment with added glucose, but phagotrophic activity was much higher than in the nutrient enriched treatments. Phagotrophic activity was also high in controls, although the phototroph assemblage was dominated by non-phagocytizing algae. These results indicate that phagotrophic activity in Dinobryon growing under high light conditions may be most advantageous when these cells are nutrient limited.

During the survey of Wheeler Pond two weeks prior to this study it was found that dissolved inorganic $\mathrm{PO}_{4}{ }^{-3}$ was less than $0.46 \mu \mathrm{M}$ (Chapter 3 ). These concentrations have been found to limit the growth of two species of Dinobryon in culture experiments (Lehman, 1976). Higher levels of phagotrophic activity observed in the controls and the glucose treatment relative to nutrient supplemented treatments indicate that phagotrophy 
may be important as a source of $\mathrm{N}$ or $\mathrm{P}$ for Dinobryon. The small fraction of phagotrophically active Dinobryon cells observed in NP and GNP treatments indicated that consumption continued at a low level even in the presence of added nutrients, though. A few bacteria cell-1 $\mathrm{d}^{-1}$ may therefore be important for good growth of this alga in the light.

The preliminary results of this study are consistent with the hypothesis that nutrient acquisition is a secondary function for phagotrophy in Dinobryon that may influence grazing activity by this alga, and that the primary function of phagotrophic behavior in Dinobryon may be to provide essential growth factors. The nutrient status of aquatic environments where Dinobryon is abundant may therefore play a role in determining the grazing impact of this alga and its contribution to energy and nutrient flow in planktonic food webs. 


\section{REFERENCES}

Andersson, A., Falk, S., Samuelsson, G. \& Hagström, Å. 1989 Nutritional characteristics of a mixotrophic nanoflagellate, Ochromonas sp. Microbial Ecology 17, $117-128$

Azam, F., Fenchel, T., Field, J. G., Gray, J. S., Meyer-Reil, L. A. \& Thingstad, F. 1983 The ecological role of water-column microbes in the sea. Marine Ecology Progress Series 10, 257-263

Berninger, U.-G., Caron, D. A. \& Sanders, R. W. 1992 Mixotrophic algae in three icecovered lakes of the Pocono Mountains, U.S.A. Freshwater Biology 28, 263-272

Bird, D. F. \& Kalff, J. 1986 Bacterial grazing by planktonic lake algae. Science 231, 493-495

Bird, D. F. \& Kalff, J. 1987 Algal phagotrophy: Regulating factors and importance relative to photosynthesis in Dinobryon (Chrysophyceae). Limnology and Oceanography 32, 277-284

Bird, D. F. \& Kalff, J. 1989 Phagotrophic sustenance of a metalimnetic phytoplankton peak. Limnology and Oceanography 34, 155-162

Caron, D. A. 1983 Technique for enumeration of heterotrophic and phototrophic nanoplankton, using epifluorescence microscopy, and comparison with other procedures. Applied and Environmental Microbiology 46, 491-498

Caron, D. A., Sanders, R. W., Lim, E. L., Marrasé, C., Amaral, L. A., Whitney, S., Aoki, R. B. \& Porter, K. G. 1992 Light-dependent phagotrophy in the freshwater mixotrophic chrysophyte Dinobryon cylindricum. Microbial Ecology 25, 93-111

Fenchel, T. 1982 Ecology of heterotrophic microflagellates. II. Bioenergetics and growth. Marine Ecology Progress Series 8, 225-231

Hutner, S. H. \& Provasoli, L. 1951 The phytoflagellates. In Biochemistry and Physiology of Protozoa vol. 1 (Lwoff, A., eds.). Academic Press, New York. pp. 27128.

Kemp, P. F., Sherr, B. F., Sherr, E. B. \& Cole, J. J. 1993 Handbook of methods in aquatic microbial ecology. Lewis Publishers, Boca Raton.

Kimura, B. \& Ishida, Y. 1986 Possible phagotrophic feeding of bacteria in a freshwater red tide Chrysophyceae Uroglena americana. Bulletin of the Japanese Society of Scientific Fisheries 52, 697-701

Kimura, B. \& Ishida, Y. 1989 Phospholipid as a growth factor of Uroglena americana, a red tide Chrysophyceae in Lake Biwa. Nippon Suisan Gakkaishi 55, 799-804

Lehman, J. T. 1976 Ecological and nutritional studies on Dinobryon Ehrenb: seasonal periodicity and the phosphate toxicity problem. Limnology and Oceanography 21, 646658 
Nygaard, K. \& Tobiesen, A. 1993 Bacterivory in algae: A survival strategy during nutrient limitation. Limnology and Oceanography 38, 273-279

Pascher, A. 1911 Cyrtophora, eine neue tentakeltragende Chrysomonade aus franzensbad und ihre verwandten. Ber. Deutsch. Bot. Ges. 29, 112-125

Pomeroy, L. R. 1974 The ocean's food web, a changing paradigm. Bioscience 24, 499-504

Porter, K. G. 1988 Phagotrophic phytoflagellates in microbial food webs. Hydrobiologia 159, 89-97

Porter, K. G. \& Feig, Y. S. 1980 The use of DAPI for identifying and counting aquatic microflora. Limnology and Oceanography 25, 943-948

Sanders, R. W. \& Porter, K. G. 1988 Phagotrophic phytoflagellates. Advances in Microbial Ecology 10, 167-192

Sanders, R. W., Porter, K. G., Bennett, S. J. \& DeBiase, A. E. 1989 Seasonal patterns of bacterivory by flagellates, ciliates, rotifers, and cladocerans in a freshwater planktonic community. Limnology and Oceanography 34, 673-687

Sanders, R. W., Porter, K. G. \& Caron, D. A. 1990 Relationship between phototrophy and phagotrophy in the mixotrophic chrysophyte Poterioochromonas malhamensis. Microbial

Ecology 19, 97-109

Sandgren, C. D. 1988 The ecology of Chrysophyte flagellates: Their growth and perennation strategies as freshwater phytoplankton. In Growth and reproduction strategies of freshwater phytoplankton (Sandgren, C. D., eds.). Cambridge University Press, Cambridge. pp. 9-104.

Saunders, P. A. 1992 Phytoplankton production and limnological characteristics of twelve Adirondack seepage lakes. Master of Arts thesis, Indiana University, Department of Biology.

Sherr, B. \& Sherr, E. 1983 Enumeration of heterotrophic microprotozoa by epifluorescence microscopy. Estuarine and Coastal Shelf Science 16, 1-17

Sherr, B. F., Sherr, E. B. \& Fallon, R. D. 1987 Use of monodispersed, fluorescently labeled bacteria to estimate in situ protozoan bacterivory. Applied and Environmental Microbiology 53, 958-965

Sherr, E. B., Caron, D. A. \& Sherr, B. F. 1993 Staining of heterotrophic protists for visualization via epifluorescence microscopy. In Current Methods in Aquatic Microbial Ecology (Kemp, P., Cole, J., Sherr, B. \& Sherr, E., eds.). Lewis Publishers, pp. 213228.

Vadstein, O., Jensen, A., Olsen, Y. \& Reinertsen, H. 1988 Growth and phosphorus status of limnetic phytoplankton and bacteria. Limnology and Oceanography 33, 489503

Veen, A. 1991 Ecophysiological studies on the phagotrophic phytoflagellate Dinobryon divergens Imhof. Ph.D. thesis, Universiteit van Amsterdam. 


\section{CHAPTER 5}

Summary and Perspectives 


\section{SUMMARY AND PERSPECTIVES}

A large part of this dissertation has been devoted to expanding our knowledge of the occurrence of mixotrophs in aquatic ecosystems, primarily unicellular mixotrophic algae in the nanoplankton size range $(2-20 \mu \mathrm{m})$, in order to provide a basis for incorporation of mixotrophy into microbial food web trophodynamics. Much of the work conducted so far on this topic has targeted freshwater environments. This dissertation, however, contains the first detailed reports on the vertical distribution and abundance of mixotrophic nanoplankton in an oligotrophic open ocean environment and in semi-enclosed coastal lagoons. In addition, further documentation is provided on the occurrence of mixotrophic nanoplankton is some newly examined freshwater plankton communities. Specifically, the absolute and relative abundances of mixotrophic nanoplankton were documented at nine stations in the Sargasso Sea (Chapter 2), in three coastal salt ponds located in Falmouth, Massachusetts, (Chapter 3), and in nine freshwater seepage ponds located in the Adirondack Mountains of New York (Chapter 3).

In summary, mixotrophic algal abundances (MNAN) in surface waters of the Sargasso Sea in spring ranged from less than a few MNAN ml-1 to approximately 140 MNAN ml-1. These abundances represented from $<5 \%$ to more than $50 \%$ of the nanoplanktonic algal assemblage. Despite the fact that absolute abundances of mixotrophic algae in the coastal ponds during summer were similar to absolute abundances in surface waters of the Sargasso Sea $\left(<15 \mathrm{MNAN} \mathrm{ml}^{-1}\right.$ to $142 \mathrm{MNAN} \mathrm{ml}^{-}$ 1), mixotrophic algae were not a major component of the total nanoplanktonic algal assemblage $(<2 \%)$ in any of these coastal ponds. Mixotrophic algae were found to be an important component of the nanoplanktonic algal assemblage in at least one of the Adirondack seepage ponds during summer. Absolute abundances of individuals of the mixotrophic chrysophyte genus Dinobryon ranged from $\sim 2.5 \times 10^{3}$ to $\sim 2 \times 10^{4} \mathrm{ml}^{-1}$ in the 
upper water column of Wheeler Pond and nearly $50 \%$ of this population was phagotrophically active. Phagotrophically active Dinobryon cells along with other solitary and colonial mixotrophic algae accounted for nearly $25 \%\left(1.1 \times 10^{4} \mathrm{ml}^{-1}\right)$ of the total nanoplanktonic algal assemblage in this pond. Mixotrophic algae in two other seepage ponds accounted for $\sim 15 \%$ of the nanoplanktonic algal assemblage with abundances $<1 \times 10^{3} \mathrm{ml}^{-1}$. Mixotrophic algal abundances ranged from $<200 \mathrm{ml}^{-1}$ to $\sim 1 \times 10^{3} \mathrm{ml}^{-1}$ in the remaining six ponds that were examined, but their numerical contribution to the total nanoplanktonic algal assemblage was less than $5 \%$ in each of the ponds. The results presented in this dissertation and in other studies (Bennett et al., 1990; Berninger et al., 1992) demonstrate that the occurrence of mixotrophic nanoplankton is a widespread phenomenon in aquatic ecosystems, but clearly their abundances and numerical importance vary (Table 5.1).

Phagotrophy has been hypothesized to play a variety of roles in the nutrition of mixotrophic algae, which include acquisition of carbon, major nutrients ( $\mathrm{N}$ and $\mathrm{P}$ ) or specific growth factors (i.e. vitamins, phospholipids) important for the growth and survival of these algae. Factors that affect the phagotrophic behavior of these algae presumably are important in determining the distribution and abundance of mixotrophic algae in nature and may influence their contribution to bacterivory. The remainder of this dissertation addresses the importance of certain physical, chemical and biological factors in determining the abundance of mixotrophic algae in nature. Chapters 2 and 4 report the results of field experiments that were designed to examine the influence of light, dissolved nutrients and prey density on mixotrophic nanoplankton abundances in surface waters of the Sargasso Sea and in one Adirondack seepage pond . There was evidence from these experiments that the abundance of mixotrophic algae and/or their phagotrophic activity decreased with nutrient enrichment. The results from experiments in the Sargasso Sea provided support for the hypothesis that phagotrophy allows mixotrophic algae in oligotrophic surface waters of this open ocean environment to 
Table 5.1. Abundances of mixotrophic nanoplankton in marine and freshwater plankton communities. Mixotrophs were identified as individual cells $2-20 \mu \mathrm{m}$ in size with autofluorescent chloroplasts and ingested fluorescently labeled tracer particles using epifluorescence microscopy. "+" indicates mixotrophic nanoplankton abundances were $<5 \%$ of total nanoplanktonic algal abundances. In cases where no relative abundance is reported, known mixotrophic species were enumerated, but $\%$ mixotrophy was not documented.

\begin{tabular}{ccccc}
\hline & & Abundance & $\%$ of Total Algal & \\
$\left(\mathrm{ml}^{-1}\right)$ & Nanoplankton & Reference \\
\hline
\end{tabular}

\section{Open Ocean}

\begin{abstract}
$31^{\circ} 51.90 \mathrm{~N}, 64^{\circ} 49.80 \mathrm{~W}$ $32^{\circ} 07.05 \mathrm{~N}, 64^{\circ} 19.30 \mathrm{~W}$ $31^{\circ} 51.90 \mathrm{~N}, 64^{\circ} 19.30 \mathrm{~W}$ $31^{\circ} 53.58 \mathrm{~N}, 63^{\circ} 58.80 \mathrm{~W}$ $32^{\circ} 07.58 \mathrm{~N}, 64^{\circ} 20.20 \mathrm{~W}$ $32^{\circ} 06.80 \mathrm{~N}, 64^{\circ} 19.91 \mathrm{~W}$ $32^{\circ} 05.00 \mathrm{~N}, 64^{\circ} 21.21 \mathrm{~W}$ $25^{\circ} 59 \mathrm{~N}, 64^{\circ} 30 \mathrm{~W}$ $30^{\circ} 26 \mathrm{~N}, 64^{\circ} 30 \mathrm{~W}$
\end{abstract}

Coastal

Perch Pond, MA
Oyster Pond, MA
Salt Pond, MA

Freshwater

Round Pond, NY

$\begin{array}{lc}\text { algal nanoplankton } & <26 \\ \text { algal nanoplankton } & <19 \\ \text { algal nanoplankton } & <6 \\ \text { algal nanoplankton } & <6 \\ \text { algal nanoplankton } & <4 \\ \text { algal nanoplankton } & 144 \\ \text { algal nanoplankton } & 69 \\ \text { algal nanoplankton } & 25 \\ \text { algal nanoplankton } & 38\end{array}$

100

148

algal nanoplankton

15

algal nanoplankton

algal nanoplankton

186
$+$

$+$

$+$

$+$

$+$

53

50

6

$+$

Chapter 2

Chapter 2

Chapter 2

Chapter 2

Chapter 2

Chapter 2

Chapter 2

Chapter 2

Chapter 2

Chapter 3

Chapter 3

Chapter 3
$+$

$+$

$+$

$+$

Chapter 3 
Freshwater (continued)

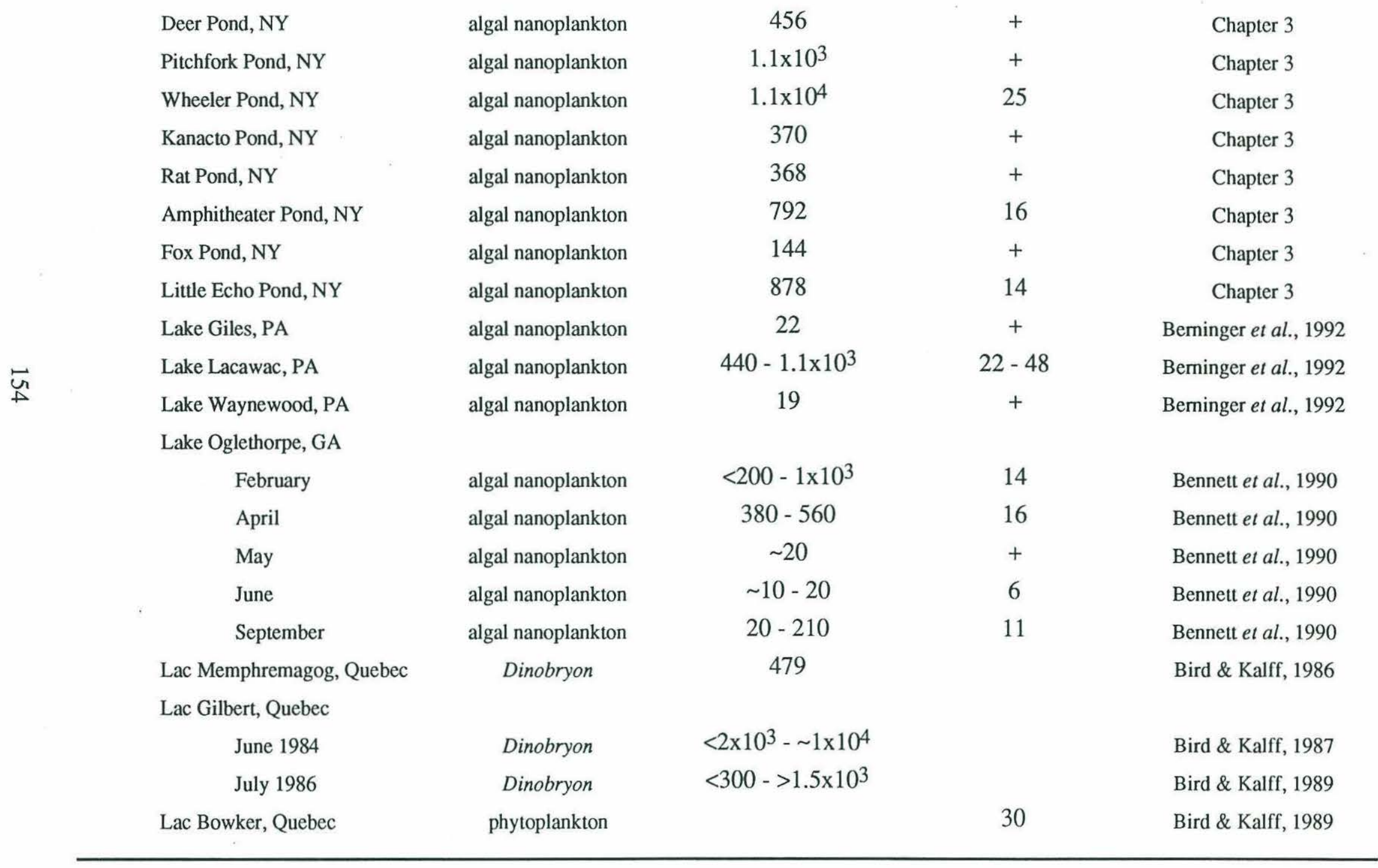


compete with other purely phototrophic algae during periods of low nutrient concentrations. This trophic behavior may therefore allow mixotrophic algae to become numerically importance in surface waters of the Sargasso Sea on occasion. The efficiency of nutrient cycling in open ocean microbial food webs may therefore be enhanced during periods of low nutrient concentrations as a consequence of nanoplanktonic algal phagotrophy. Further studies that address the contribution of photosynthesis and phagotrophy to the growth of mixotrophic nanoplankton and their contribution to bacterivory in open ocean environments may substantiate this hypothesis.

Preliminary results obtained from the experiment conducted in Wheeler Pond suggested that the availability of nutrients affected the phagotrophic activity of members of at least one mixotrophic chrysophyte genus (Dinobryon) common in temperate and northern oligotrophic lakes. The percent of Dinobryon individuals that were phagotrophically active was found to decrease with nutrient enrichment, but the actual abundances of this mixotrophic alga appeared to increase under these conditions. Phagotrophy by Dinobryon persisted to some degree even with nutrient enrichment, though. The results from this experiment, although preliminary, therefore supported the hypothesis that phagotrophy by Dinobryon may be primarily important as a means of acquiring specific growth factors, but suggested that nutrient availability may influence the level of phagotrophic activity in this alga, and may therefore play a role in determining the importance of this alga to total bacterivory. Dinobryon has been found to have an important impact on total bacterivory in some freshwater plankton communities (Bird \& Kalff, 1986; Sanders et al., 1989). Future research that focuses on the role of specific nutrients and other factors (i.e. the nutritional quality of bacterial prey) in controlling the rate of phagotrophic activity in Dinobryon may therefore help determine when and where this mixotroph will have a large impact on bacterivory and the flow of energy and nutrients through microbial food webs. 
Experiments to examine factors that may influence the abundance of mixotrophic nanoplankton in the coastal ponds were not conducted. Although the relative importance of mixotrophic nanoplankton was found to be consistently low in these ponds at the time of study, mixotrophic ciliates in the microplankton size range $(20-200 \mu \mathrm{m})$ were found to be relatively abundant in one coastal salt pond. Mixotrophic dinoflagellates were also observed in another pond during the study. A few studies have recently documented the presence of high abundances of mixotrophic dinoflagellates and ciliates in the microplankton assemblage of some estuarine environments (Stoecker et al., 1981; McManus \& Fuhrman, 1986; Stoecker et al., 1987; Stoecker et al., 1989; Bockstahler \& Coats, 1993). Although mixotrophy can be common among the nanoplankton assemblage in freshwater, open ocean and other coastal environments (Bird \& Kalff, 1986; Bird \& Kalff, 1987; Bird \& Kalff, 1989; Dahl et al., 1989; Johnsen \& Lein, 1989, Chapter 2; Bennett et al., 1990; Berninger et al., 1992), this trophic behavior may be more prevalent among the microplankton assemblage in estuarine environments.

Energy and nutrient cycling in aquatic environments in which mixotrophy predominates in the microplankton assemblage is likely to differ from energy and nutrient cycling in environments in which this trophic behavior is absent or predominates in the nanoplankton assemblage. Most of the regeneration of inorganic nutrients in aquatic microbial food webs is commonly thought to occur at the level of the nanoplankton (Fig. 5.2, Food Chain I). Mixotrophic nanoplankton that consume bacteria to obtain nutrients presumably are more efficient at retaining these nutrients than their heterotrophic counterparts. Nutrients may therefore be transferred more efficiently from bacteria to higher trophic levels in some freshwater and open ocean plankton communities where mixotrophic nanoplankton may predominate, particularly during periods of nutrient limitation. Most of the nutrients regenerated under these conditions would more than likely occur at the level of the microplankton (Fig. 5.2, Food Chain II). Nutrient transfer in plankton communities where mixotrophic microplankton 
predominate (e.g. some estuarine environments) would presumably be enhanced as well, but the level of enhancement may not be as great as in the previous scenario because a large fraction of the nutrients would be regenerated by heterotrophic nanoplankton prior to reaching the microplankton assemblage (Fig. 5.2, Food Chain III). 


\begin{tabular}{|c|c|c|}
\hline $\begin{array}{c}\text { Microbial Food } \\
\text { Chain } \\
\text { I }\end{array}$ & $\begin{array}{c}\text { Microbial Food } \\
\text { Chain } \\
\text { II }\end{array}$ & $\begin{array}{c}\text { Microbial Food } \\
\text { Chain } \\
\text { III }\end{array}$ \\
\hline $\begin{array}{l}6.4 \mathrm{~g} \mathrm{C} \\
0.9 \mathrm{~g} \mathrm{~N}\end{array}$ & $\begin{array}{l}28 \mathrm{~g} \mathrm{C} \\
4 \mathrm{~g} \mathrm{~N}\end{array}$ & $\begin{array}{l}16 \mathrm{~g} \mathrm{C} \\
2.3 \mathrm{~g} \mathrm{~N}\end{array}$ \\
\hline copepods & copepods & copepods \\
\hline $\begin{array}{c}\mathrm{C}: \mathrm{N}=7 \\
\mathrm{GGE}=10 \%\end{array}$ & $\begin{array}{c}\mathrm{C}: \mathrm{N}=7 \\
\mathrm{GGE}=10 \%\end{array}$ & $\begin{array}{c}\mathrm{C}: \mathrm{N}=7 \\
\mathrm{GGE}=10 \%\end{array}$ \\
\hline $\begin{array}{l}64 \mathrm{~g} \mathrm{C} \\
9.1 \mathrm{~g} \mathrm{~N}\end{array}$ & $\begin{array}{l}280 \mathrm{~g} \mathrm{C} \\
40 \mathrm{~g} \mathrm{~N}\end{array}$ & $\begin{array}{l}160 \mathrm{~g} \mathrm{C} \\
22.8 \mathrm{~g} \mathrm{~N}\end{array}$ \\
\hline $\begin{array}{l}\text { heterotrophic } \\
\text { ciliates }\end{array}$ & $\begin{array}{l}\text { heterotrophic } \\
\text { ciliates }\end{array}$ & $\begin{array}{l}\text { mixotrophic } \\
\text { ciliates }\end{array}$ \\
\hline $\begin{array}{c}\mathrm{C}: \mathrm{N}=7 \\
\mathrm{GGE}=40 \%\end{array}$ & $\begin{array}{c}\mathrm{C}: \mathrm{N}=7 \\
\mathrm{GGE}=40 \% \\
\end{array}$ & $\begin{aligned} \mathrm{C}: \mathrm{N} & =7 \\
\mathrm{GGE}(\mathrm{N}) & =100 \%\end{aligned}$ \\
\hline $\begin{array}{l}160 \mathrm{~g} \mathrm{C} \\
22.8 \mathrm{~g} \mathrm{~N}\end{array}$ & $\begin{array}{l}700 \mathrm{~g} \mathrm{C} \\
100 \mathrm{~g} \mathrm{~N}\end{array}$ & $\begin{array}{l}160 \mathrm{~g} \mathrm{C} \\
22.8 \mathrm{~g} \mathrm{~N}\end{array}$ \\
\hline $\begin{array}{l}\text { heterotrophic } \\
\text { flagellates }\end{array}$ & $\begin{array}{l}\text { mixotrophic } \\
\text { flagellates }\end{array}$ & $\begin{array}{l}\text { heterotrophic } \\
\text { flagellates }\end{array}$ \\
\hline $\begin{array}{c}\mathrm{C}: \mathrm{N}=7 \\
\mathrm{GGE}=40 \%\end{array}$ & $\begin{aligned} \mathrm{C}: \mathrm{N} & =7 \\
\mathrm{GGE}(\mathrm{N}) & =100 \%\end{aligned}$ & $\begin{array}{c}\mathrm{C}: \mathrm{N}=7 \\
\mathrm{GGE}=40 \%\end{array}$ \\
\hline $\begin{array}{l}400 \mathrm{~g} \mathrm{C} \\
100 \mathrm{~g} \mathrm{~N}\end{array}$ & $\begin{array}{l}400 \mathrm{~g} \mathrm{C} \\
100 \mathrm{~g} \mathrm{~N}\end{array}$ & $\begin{array}{l}400 \mathrm{~g} \mathrm{C} \\
100 \mathrm{~g} \mathrm{~N}\end{array}$ \\
\hline bacteria & bacteria & bacteria \\
\hline $\mathrm{C}: \mathrm{N}=4$ & $\mathrm{C}: \mathrm{N}=4$ & $\mathrm{C}: \mathrm{N}=4$ \\
\hline
\end{tabular}

Figure 5.2. Hypothetical transfer of energy (C) and nutrients (e.g. nitrogen) through microbial food chains dominated by heterotrophic nanoplankton and microplankton (I), mixotrophic (obligate photophagotrophy) nanoplankton and heterotrophic microplankton (II), and heterotrophic nanoplankton and mixotrophic (chloroplast-retaining) microplankton (III). Heterotroph gross growth efficiencies (GGE) and C:N ratios taken from Caron (1991). 


\section{REFERENCES}

Bennett, S. J., Sanders, R. W. \& Porter, K. G. 1990 Heterotrophic, autotrophic and mixotrophic nanoflagellates: seasonal abundances and bacterivory in a eutrophic lake. Limnology and Oceanography 35, 1821-1832

Berninger, U.-G., Caron, D. A. \& Sanders, R. W. 1992 Mixotrophic algae in three icecovered lakes of the Pocono Mountains, U.S.A. Freshwater Biology 28, 263-272

Bird, D. F. \& Kalff, J. 1986 Bacterial grazing by planktonic lake algae. Science 231, 493-495

Bird, D. F. \& Kalff, J. 1987 Algal phagotrophy: Regulating factors and importance relative to photosynthesis in Dinobryon (Chrysophyceae). Limnology and

Oceanography 32, 277-284

Bird, D. F. \& Kalff, J. 1989 Phagotrophic sustenance of a metalimnetic phytoplankton peak. Limnology and Oceanography 34, 155-162

Bockstahler, K. R. \& Coats, D. W. 1993 Spatial and temporal aspects of mixotrophy in Chesapeake Bay dinoflagellates. Journal of Eukaryotic Microbiology 40, 49-60

Caron, D. A. 1991 Evolving role of protozoa in aquatic nutrient cycles. In Protozoa and their role in marine processes vol. 25 (Reid, P. C., Turley, C. M. \& Burkill, P. H., eds.). Springer-Verlag, Berlin. pp. 387-415.

Dahl, D., Lindahl, O., Paasche, E. \& Throndsen, J. 1989 The Chrysochromulina polylepis bloom in Scandinavian waters during Spring, 1988. In Novel Phytoplankton Blooms: causes and impacts of recurrent brown tides and other unusual blooms (Cosper, E. M., Bricelj, V. M. \& Carpenter, E. J., eds.). Springer-Verlag, Berlin. pp. 383-405.

Johnsen, T. M. \& Lein, T. E. 1989 Prymnesium parvum Carter, (Prymnesiophyceae) in association with macroalgae in Ryfylke, southwestern Norway. Sarsia 74, 277-281

McManus, G. B. \& Fuhrman, J. A. 1986 Photosynthetic pigments in the ciliate Laboea strobila from Long Island Sound, USA. Journal of Plankton Research 8, 317-327

Sanders, R. W., Porter, K. G., Bennett, S. J. \& DeBiase, A. E. 1989 Seasonal patterns of bacterivory by flagellates, ciliates, rotifers, and cladocerans in a freshwater planktonic community. Limnology and Oceanography 34, 673-687

Stoecker, D., Michaels, A. E. \& Davis, L. H. 1987 Large proportion of marine planktonic ciliates found to contain functional chloroplasts. Nature 326, 790-792

Stoecker, D., Taniguchi, A. \& Michaels, A. E. 1989 Abundance of autotrophic, mixotrophic and heterotrophic planktonic ciliates in shelf and slope waters. Marine Ecology Progress Series 50, 241-154

Stoecker, D. K., Guillard, R. R. L. \& Kavee, R. M. 1981 Selective predation by Favella ehrenbergii (Tintinnia) on and among dinoflagellates. Biological Bulletin 160,136-145 


\section{BIOGRAPHICAL NOTE}

Andrea L. Arenovski graduated from Dennis-Yarmouth Regional High School (MA) in June 1984 and entered the University of North Carolina at Wilmington (UNCW) in August 1984. Andrea later graduated summa cum laude from UNCW in May 1988 with a Bachelor of Science degree in Biology and Marine Biology (double concentration). She entered the MIT/WHOI Joint Program in Biological Oceanography immediately following graduation from UNCW. Her first three years of graduate school were spent studying the physiological ecology of salt marsh cordgrass (Spartina alterniflora) in the Great Sippewissett Salt Marsh under the direction of Brian L. Howes. Andrea later joined the laboratory of David A. Caron in June of 1991. Her work on the ecology of mixotrophic algae is described in this thesis which was completed in September 1994. Andrea has accepted a position with the Massachusetts Bay Marine Studies Consortium in Boston, MA, and begins work as Program Manager and Director of Science in November 1994.

\section{Honors and Awards}

- WHOI Summer Student Fellowship, 1987

- Who's Who in American Universities and Colleges, 1987

- UNCW Undergraduate Research Fellowship, 1988

- National Collegiate Natural Sciences Award, 1988

- Switzer Environmental Fellowship, 1989

- Ocean Ventures Fund Award, 1992

\section{Professional Societies}

- Sigma Xi Scientific Research Society

- American Society of Limnology and Oceanography

- Estuarine Research Federation

- North East Estuarine Research Society

\section{Publications}

- Arenovski, A.L. \& B.L. Howes. (1992). Lacunal allocation and gas transport capacity in the salt marsh cordgrass Spartina alterniflora. Oecologia 90: 316-322.

- Arenovski, A.L., E.L. Lim \& D.A. Caron. (submitted) Mixotrophic nanoplankton in oligotrophic surface waters of the Sargasso Sea may employ phagotrophy to obtain major nutrients. Journal of Plankton Research.

- Arenovski, A.L. \& P.A. Bukaveckas. (in prep) Distribution and abundance of mixotrophic nanoplankton in nine Adirondack seepage ponds and three coastal salt ponds.

- Arenovski, A.L. (in prep) The importance of phagotrophy in the nutrition of mixotrophic nanoplankton in an Adirondack seepage pond. 
